UNIVERSIDADE DE SÃO PAULO - USP

PROGRAMA INTERUNIDADES DE PÓS-GRADUAÇÃO EM ENERGIA

PIPGE

(EP/FEA/IEE/IF)

BIOMASS-TO-LIQUIDS: UMA CONTRIBUIÇÃO AO ESTUDO DA OBTENÇAO DE BIOCOMBUSTÍVEIS SINTÉTICOS ATRAVÉS DA SÍNTESE FISCHER-TROPSCH

AIRES DUARTE DA FONSECA 
AIRES DUARTE DA FONSECA

\section{BIOMASS-TO-LIQUIDS: UMA CONTRIBUIÇÃO AO ESTUDO DA OBTENÇAO DE BIOCOMBUSTÍVEIS SINTÉTICOS ATRAVÉS DA SÍNTESE FISCHER-TROPSCH}

Dissertação apresentada ao Programa Interunidades de Pós-Graduação em Energia da Universidade de São Paulo (Escola Politécnica / Faculdade de Economia e Administração / Instituto de Eletrotécnica e Energia / Instituto de Física) para obtenção do título de Mestre em Energia.

Orientadora: Prof. ${ }^{\mathrm{a}}$ Dr. ${ }^{\mathrm{a}}$ Patrícia Helena Lara dos Santos Matais 
AUTORIZO A REPRODUÇÃO E DIVULGAÇÃO TOTAL OU PARCIAL DESTE TRABALHO, POR QUALQUER MEIO CONVENCIONAL OU ELETRÔNICO, PARA FINS DE ESTUDO E PESQUISA, DESDE QUE CITADA A FONTE.

FICHA CATALOGRÁFICA

Duarte, Aires.

Biomass-to-liquids: uma contribuição ao estudo da obtenção de biocombustíveis sintéticos através da síntese Fischer-Tropsch / Aires Duarte; orientadora Patrícia Helena Lara dos Santos Matai. - São Paulo, 2009.

143p.: il.; $30 \mathrm{~cm}$.

Dissertação (Mestrado - Programa Interunidades de Pós-Graduação em Energia) - EP / FEA / IEE / IF da Universidade de São Paulo.

1. Energia de biomassa 2. Gaseificação 3. Biocombustíveis I. Título. 
DEDICATÓRIA

Dedico este trabalho aos bons amigos feitos, nesses meses de intenso estudo, na Universidade de São Paulo. 


\section{AGRADECIMENTOS}

A toda equipe e colegas do Programa de Recursos Humanos (PRH4) da Agência Nacional de Petróleo, Gás Natural e Biocombustíveis (ANP) pelo suporte a esta pesquisa e pelas oportunidades proporcionadas para seu aperfeiçoamento, em especial, ao professor Miguel Edgar Morales Udaeta por ter enxergado além da imagem do "jovem roqueiro" e ter me concedido essa chance única no verão de 2007; ao Programa de Pós-Graduação em Energia, seus professores e colaboradores, pelo meu aprendizado e crescimento como pesquisador; a equipe da biblioteca Professor Fonseca Telles pela colaboração e paciência com meus constantes atrasos. Aos amigos professores José Roberto "Betinho" e Maria José Urioste Rosso da Universidade Salesiana de São Paulo; de igual forma, Andie Trajano, Andy Lopez e Ésoly Santos pelo valioso apoio nos meus primeiros passos dentro do imenso mundo da pesquisa científica. A Francisco Del Moral Hernández, por seus sempre bem-vindos aconselhamentos. A toda a equipe do Centro Nacional de Referência em Biomassa (CENBIO) pela pronta ajuda, em especial, as pesquisadoras Sandra Apolinário e Patrícia Guardabassi; ao pesquisador Ademar Hakuo Ushima, do Instituto de Pesquisas Tecnológicas (IPT), por sua paciência e muito valiosa colaboração. Aos meus colegas de estudo, ora professores, ora boêmios, que estiveram comigo, por tantos meses, em tantas aulas e em tantos bares; aos sempre amigos de Lorena, paladinos de muitas lutas em masmorras; aos amigos músicos que, com suas canções, embalaram meus estudos; a minha família, por ter me dado todo o apoio que eu poderia precisar. Aos professores José Luís de Paiva, Sandra Velázquez, Alfredo Maiorano e Augusto Neiva por gentilmente se comprometerem com esse estudo; e, de forma honrosa, a minha professora orientadora, Patrícia Helena Lara dos Santos Matai, por ter acreditado em mim, com toda sua dedicação, sabedoria, constante presença e um exemplar bom humor; e por fim, a todos os demais que, direta ou indiretamente, colaboraram na execução deste trabalho. 
A segunda geração de biocombustíveis tenta reduzir para uma escala de dias o processo que a natureza demora milhões de anos para fazer, que é gerar hidrocarbonetos a partir de matéria orgânica.

(Carlos Tadeu da Costa Fraga) 


\section{RESUMO}

DUARTE, Aires. Biomass-to-liquids: uma contribuição ao estudo da obtençãode biocombústiveis sintéticos através da síntese Fischer-Tropsch.2009. 143p. Dissertação (Mestrado em Energia) - Programa Interunidades de Pós-Graduação em Energia da Universidade de São Paulo, 2009.

O que se pretendeu estudar é um caminho alternativo para a obtenção de biocombustíveis sintéticos, para uso veicular, utilizando-se para tal a rota tecnológica conhecida como Biomass-to-Liquids (BTL) que consiste na utilização da síntese Fischer-Tropsch para a "construção" de cadeias de hidrocarbonetos a partir de unidades monoméricas obtidas de uma mistura gasosa majoritariamente formada por monóxido de carbono $(\mathrm{CO})$ e hidrogênio $(\mathrm{H})$, conhecida como syngas - quando proveniente de fontes energéticas fósseis como o carvão mineral ou o gás natural - ou também biosyngas - quando proveniente de matéria-prima carbonada renovável, como é o caso da biomassa. O presente trabalho visa abordar o começo dessa cadeia produtiva ao introduzir um conceito para biomassa e os meios para obtenção do biosyngas através do processo conhecido como gaseificação; é feita uma menção à obtenção bem sucedida de biosyngas nas dependências do Instituto de Pesquisas Tecnológicas (IPT) de São Paulo. Segue-se com a utilização desse insumo na síntese Fischer-Tropsch - largamente utilizada ao longo do século XX em países específicos para abastecimento da frota veicular local - onde seu princípio fundamental é introduzido, assim como os principais mecanismos de formação de cadeias de hidrocarbonetos de diferentes pesos moleculares permitindo assim a obtenção de gasolina e óleo diesel. Essa dissertação apresenta conceitos para a palavra combustível, da mesma forma que introduz os combustíveis fósseis, seus importantes derivados e suas propriedades gerais para que seja possível, adiante, utilizá-los como comparativo com os biocombustíveis sintéticos; é apresentada a evolução histórica dessa tecnologia e são também abordadas a primeira e segunda gerações de biocombustíveis, para se trazer dados que indiquem as vantagens do óleo diesel Fischer-Tropsch quando comparado com seu equivalente oriundo da petroquímica convencional e por fim demonstrar sua superior qualidade sócio-ambiental como biocombustível sintético para o futuro da matriz energética mundial.

Palavras-chave: Biomassa. Gaseificação. Síntese Fischer-Tropsch. Biocombustívies sintéticos. Biomass-to-Liquids (BTL). 


\begin{abstract}
DUARTE, Aires. Biomass-to-liquids: a contribution to the synthetic biofuels obtaining study through Fischer-Tropsch synthesis.2009.

143p. Master's Dissertation - Post-Graduation - Inter Units Energy Related Graduate Program, Universidade de São Paulo, 2009.

What is supposed to be on board of this study consists in an alternative way focused on vehicular use synthetic fuels obtaining, using as main process the technological route known as Biomass-to-Liquids (BTL), which one consists on Fischer-Tropsch synthesis use for hydrocarbons chain "building" starting from monomer units obtained from a gas mixture made up mostly by carbon monoxide $(\mathrm{CO})$ and hydrogen $(\mathrm{H})$, known as syngas - from fossil energy sources such as coal or natural gas - or also biosyngas - from carbonaceous renewable raw materials, such as biomass. This paper aims to address the beginning of the production chain in order to introduce a concept for biomass and the biosyngas obtaining means through the process known as gasification, a reference is made to a successful biosyngas obtaining the dependencies at the Institute for Technological Research (IPT) from Sao Paulo. Then there is the use of that input in the Fischer-Tropsch synthesis - widely used throughout the twentieth century, in specific countries, to supply the local vehicle fleet - where its basic principle is introduced, as well as the main hydrocarbons chain formation mechanisms thus different molecular weights providing gasoline and diesel oil. This essay presents concepts for the word fuel, the same way that makes it for fossil fuels, their major products and their properties in order to use them as a comparison standard for synthetic biofuels, it was also presented the historical development of this technology and first and second generation of biofuels, in order to bring evidence to suggest the benefits of the Fischer-Tropsch diesel fuel once compared to its conventional equivalent come from the petrochemical and finally to demonstrate it as a socio-environmentally superior quality synthetic biofuel for the future of global energy matrix.
\end{abstract}

Keywords: Biomass. Gasification. Fischer-Tropsch Synthesis. Synthetic Biofuels. Biomassto-Liquids (BTL). 


\section{LISTA DE ILUSTRAÇÕES}

Figura 2.1 - Distribuição das fontes de energia na atualidade.

Figura 2.2 - Produtos que podem ser obtidos partindo-se do gás de síntese (syngas).

Figura 2.3 - Métodos primários de remoção de alcatrões.

Figura 2.4 - Métodos secundários de remoção de alcatrões.

Figura 2.5 - Bagaço de cana-de-açúcar condicionado em forma de pellets .

Figura 2.6 - Gaseificador de leito fluidizado borbulhante: fotografia e esquemático. $\quad 50$

Figura 2.7 - Gaseificador co-corrente (forma esquemática) de pellets de bagaço. 51

Figura 2.8 - Gaseificador co-corrente desenvolvido pela parceira Raudi-IPT. $\quad 52$

Figura 3.1 - Professor Franz Fischer (esquerda) e Dr. Hans Tropsch (direita). 56

Figura 3.2 - Modelo de iniciação da cadeia de hidrocarbonetos. 61

Figura 3.3 - Modelo esquemático de crescimento e terminação de cadeias de hidrocarbonetos.

Figura 3.4 - Espécies observadas sobre superfície catalítica na síntese FT. 72

Figura 3.5 - Síntese Fiscter-Tropsch segundo mecanismo alquil. $\quad 75$

Figura 3.6 - Proposição para formação de hidrocarbonetos ramificados no mecanimso alquil. $\quad 75$

Figura 3.7 - Síntese Fiscter-Tropsch segundo mecanismo alquenil. 77

Figura 3.8 - Síntese Fiscter-Tropsch segundo mecanismo enol. 78

Figura 3.9 - Síntese Fiscter-Tropsch segundo mecanismo de inserção do CO. $\quad 80$

Figura 4.1 - Fórmulas estruturais para o n-heptano e o iso-octano. 90

Figura 4.2 - Torre de destilação fracionada esquemática. $\quad 104$

Figura 4.3 - Princípio da síntese de hidrocarbonetos a partir de matéria prima $\begin{array}{ll}\text { carbonada. } & 114\end{array}$

Figura 4.4 - Rotas tecnológicas de conversão da biomassa. 116 


\section{LISTA DE GRÁFICOS}

Gráfico 3.1 - Distribuição dos produtos FT para diferentes valores de $\alpha$.

Gráfico 3.2 - Distribuição dos produtos FT para diferentes valores de $\alpha$.

Gráfico 3.3 - Variação da temperatura com taxa $\mathrm{H}_{2}$ : $\mathrm{CO}$ fixa $(\mathrm{r}=2)$.

Gráfico 3.4 - Variação da taxa (r) $\mathrm{H}_{2}$ : $\mathrm{CO}$ variando-se a pressão parcial do $\mathrm{CO}$. 70

Gráfico 3.5 - Distribuição de produtos com um catalisador à base de cobalto. 82

Gráfico 3.6 - Distribuição de produtos com um catalisador à base de ferro. 83

Gráfico 5.1 - Custos cumulativos para produção em larga escala de diesel FT. 


\section{LISTA DE TABELAS}

Tabela 2.1 - Composição elementar (\%) de diferentes tipos de biomassa.

Tabela 2.2 - Propriedades de diversas variedades de biomassas.

Tabela 2.3 - Composição elementar média (\%) do gás de gaseificação.

Tabela 2.4 - Composição típica (\%) do gás produzido pela gaseificação.

Tabela 2.5 - Redução do teor de alcatrões e material particulado utilizando diferentes métodos mecânicos de limpeza.

Tabela 2.6 - Composição (\%) do gás produzido pela de gaseificação de pellets de bagaço de cana-de-açúcar.

Tabela 2.7 - Composição (\%) do gás produzido no gaseificador Raudi-IPT.

Tabela 3.1 - Unidades industriais Fischer-Tropsch em operação.

Tabela 3.2 - Influência das variáveis de processo na distribuição dos produtos.

Tabela 4.1 - Relação entre diferentes hidrocarbonetos e octanagem (NO). 91

Tabela 4.2 - Diferentes valores sugeridos para o ${ }^{\circ} \mathrm{API} . \quad 97$

Tabela 4.3 - Principais variedades da gasolina brasileira. $\quad 109$

Tabela 4.4 - Principais variedades do óleo diesel brasileiro. 113 


\section{LISTA DE ABREVIATURAS E SIGLAS}

AEAC

AEHC

ANP

API

ASTM

ASF

ASU

AVGAS

BTL

BTX

CDM

CEFET-MG

CENPES

CFR

CSN

CTE

CTL

CTM

DME

$\mathrm{DNC}$

EP

EEV

EPA

$\mathrm{EPC}$

ETBE

EUA

FEED

FCC

FT

GEE
Álcool Etílico Anidro Combustível

Álcool Etílico Hidratado Carburante

Agência Nacional de Petróleo, Gás Natural e Biocombustíveis

American Petroleum Institute

American Society for Testing e Materials

Distribuição Anderson-Schulz-Flory

Air Separation Units

Gasolina de aviação

Biomass-to-Liquids

Benzeno, Tolueno e Xileno

Conversão Direta Microbiana

Centro de Educação Tecnológica de Minas Gerais

Centro de Pesquisas e Desenvolv. Leopoldo Américo Miguez de Melo

Cooperative Fuel Research Committee

Companhia Siderúrgica Nacional

Chumbo Tetraetila

Coal-to-Liquids

Chumbo Tetrametila

Dimetil-éter

Departamento Nacional de Combustíveis

Escola Politécnica

Enhanced Environmentally Friendly Vehicles

United States Environmental Protection Agency

Engineering, Procurement and Construction

Éter Etiltercbutila

Estados Unidos da América

Front end Engineering and Design

Fluid Cracking Catalysis ou Craqueamento Catalítico Fluido

Fischer-Tropsch

Gases de Efeito Estufa 
GLP

GNV

GTL

$\mathrm{HC}$

$\mathrm{HCC}$

HMN

HTU

IAD

IC

IEE

IPT

LTC

MEG

MMT

MON

MTBE

NASA

$\mathrm{NC}$

NIPE

NO

PCS

PCI

P\&D

PIPGE

RON

SBRT

SFS

SSI

TBA

UE

ULSD

UNICAMP

WGSR

WTI
Gás Liquefeito de Petróleo

Gás Natural Veicular

Gas-to-Liquids

Hidrocarbonetos não queimados

Hidrocraqueamento Catalítico

Hepta-metil-nonano

Hydro Termal Upgrading

Índice Antidetonante

Índice de Cetano

Instituto de Eletrotécnica e Energia

Instituto de Pesquisas Tecnológicas

Low Temperature Conversion

Metanol, etanol e gasolina

Metilpentadienilmanganês Tricarbonila

Motor Octane Number

Metil terc-butil Éter

National Aeronautics and Space Administration

Número de Cetano

Núcleo Interdisciplinar de Planejamento Energético

Número de Octanagem

Poder Calorífico Superior

Poder Calorífico Inferior

Pesquisa e Desenvolvimento

Programa Interunidades de Pós-Graduação em Energia

Research Octane Number

Serviço Brasileiro de Respostas Técnicas

Sacarificação e Fermentação Simultâneas

Sasol Synfuels International

Álcool Tercbutílico

União Européia

Ultra-low sulphur diesel

Universidade Estadual de Campinas

Water Gas Shift Reaction ou Reação de deslocamento do gás d água

West Texas Intermediate 


\section{LISTA DE SÍMBOLOS}

\begin{tabular}{|c|c|}
\hline${ }^{\circ} \mathrm{API}$ & graus API \\
\hline${ }^{\circ} \mathrm{C}$ & graus Celsius \\
\hline${ }^{\mathrm{o}} \mathrm{F}$ & graus Farenheit \\
\hline${ }^{\circ} \mathrm{GL}$ & graus Gay-Lussac \\
\hline$\Delta \mathrm{H}$ & Variação da entalpia de uma substância \\
\hline$\infty$ & Notação de infinito \\
\hline$\alpha$ & Constante de propagação de cadeias carbônicas (seletividade) \\
\hline$\beta$ & Constante de terminação de cadeias carbônicas \\
\hline$\rho$ & Densidade específica do petróleo (den.óleo/den.água) \\
\hline$\Sigma$ & Notação de somatório \\
\hline$\phi_{i}$ & Fração molar da faixa de produtos contendo $i$ átomos de carbono \\
\hline$€$ & Euro (unidade monetária) \\
\hline $\mathrm{R} \$$ & Real (unidade monetária) \\
\hline US\$ & Dólar (unidade monetária) \\
\hline $\mathrm{a}$ & Are: unidade de medida de área $=100 \mathrm{~m}^{2}$ \\
\hline atm & Atmosfera (unidade de pressão) \\
\hline bar & Unidade de pressão equivalente a $10^{5} \mathrm{~Pa}$ \\
\hline $\mathrm{C}$ & Carbono \\
\hline $\mathrm{C}_{\mathrm{n}}$ & Fração de hidrocarbonetos que possuem comprimento $n$ \\
\hline Co & Cobalto \\
\hline GJ & Giga Joules ( 1 X $10^{9}$ Joules) \\
\hline $\mathrm{Fe}$ & Ferro \\
\hline ha & Hectare: unidade de medida de área $=100$ ares $=10.000 \mathrm{~m}^{2}$ \\
\hline $\mathrm{H}$ & Hidrogênio \\
\hline $\mathrm{kJ}$ & Kilo Joules ( 1 X $10^{3}$ Joules $)$ \\
\hline $\mathrm{K}$ & Potássio \\
\hline $\mathrm{K}$ & Kelvin (unidade de temperatura) \\
\hline $\mathrm{L}$ & Litro \\
\hline $\mathrm{m}$ & metro \\
\hline $\mathrm{m}^{2}$ & metro quadrado \\
\hline $\mathrm{m}^{3}$ & metro cúbico \\
\hline
\end{tabular}




$\begin{array}{ll}\text { mol } & 1 \text { mol } \approx 6,022 \times 10^{23} \text { entidades } \\ \mathrm{O} & \text { Oxigênio } \\ \mathrm{Pa} & \text { Pascal } \\ \mathrm{Pt} & \text { Platina } \\ n & \text { Comprimento dos hidrocarbonetos } \\ \mathrm{N} & \text { Nitrogênio } \\ \mathrm{Ni} & \text { Níquel } \\ \mathrm{NO}_{\mathrm{x}} & \text { Notação para os óxidos de nitrogênio } \\ \mathrm{r}_{\mathrm{p}} & \text { Taxa de propagação das cadeias de hidrocarbonetos } \\ \mathrm{r}_{\mathrm{t}} & \text { Taxa de terminação das cadeias de hidrocarbonetos } \\ \mathrm{Re} & \text { Rênio } \\ \mathrm{Ru}_{\mathrm{S}} & \text { Rutênio } \\ \mathrm{SO}_{\mathrm{x}} & \text { Enxofre } \\ & \text { Notação para os óxidos de enxofre }\end{array}$




\section{SUMÁRIO}

1 INTRODUÇÃO 18

2 GASEIFICAÇÃO DE BIOMASSA 21

2.1 CONCEITUANDO BIOMASSA 21

2.2 INTRODUÇÃO AOS PROCESSOS DE GASEIFICAÇÃO DE BIOMASSA 25

2.2.1 Conversão térmica: Pirólise 29

2.2.2 Conversão térmica: Oxidação parcial 31

2.2.3 Conversão térmica: Reforma a vapor (gaseificação a vapor) 32

2.2.4 Reações de gaseificação 34

2.2.5 O gás de síntese $\quad 40$

2.2.6 Limpeza do gás de síntese $\quad 43$

2.2.7 Produção em escala piloto de gás de síntese no IPT 48

3 SÍNTESE FISCHER-TROPSCH

3.1 DESENVOLVIMENTO HISTÓRICO DE UMA TECNOLOGIA

3.2 A SÍNTESE FISCHER-TROPSCH $\quad 59$

3.2.1 Probabilidade de formação e crescimento de cadeias de hidrocarbonetos $\quad 59$

3.2.2 Mecanismos de formação e crescimento das cadeias de hidrocarbonetos 72

3.3.2.1 Mecanismo alquil $\quad 74$

3.3.2.2 Mecanismo alquenil $\quad 76$

3.3.2.3 Mecanismo enol 76

3.3.2.4 Mecanismo de inserção do $\mathrm{CO} \quad 79$

3.3.3 CATALISADORES DA SÍNTESE FISCHER-TROPSCH 81

4 COMBUSTÍVEIS $\quad 85$

4.1 CONCEITUANDO COMBUSTÍVEL 85

4.2 OCTANAGEM, NÚMERO E ÍNDICE DE CETANO 88

4.3 COMBUSTÍVEIS FÓSSEIS 94

$\begin{array}{lll}\text { 4.3.1 Gasolina } & 101\end{array}$

$\begin{array}{lll}\text { 4.3.1.1 Destilação fracionada } & 103\end{array}$

$\begin{array}{lll}\text { 4.3.1.2 Craqueamento (cracking) } & 105\end{array}$

4.3.1.3 Variedades da gasolina 106

$\begin{array}{lll}\text { 4.3.2 Óleo diesel } & 110\end{array}$ 
4.3.2.1 Variedades do óleo diesel 112

4.4 BIOCOMBUSTÍVEIS SINTÉTICOS 113

$\begin{array}{lll}\text { 4.4.1 Contexto histórico } & 116\end{array}$

4.4.1.1 Primeira trajetória tecnológica em combustíveis sintéticos 118

4.4.1.2 Trajetória tecnológica no pós-guerra: África do Sul 120

4.4.1.3 Segunda trajetória tecnológica em combustíveis sintéticos 122

4.4.2 Primeira geração de biocombustíveis 123

$\begin{array}{lll}\text { 4.4.3 Segunda geração de biocombustíveis } & 128\end{array}$

5 DISCUSSÃO E CONCLUSÕES 132

$\begin{array}{ll}\text { REFERENNCIAS } & 137\end{array}$ 


\section{INTRODUÇÃO}

A Comissão Mundial sobre Ambiente e Desenvolvimento definiu, em 1987, "desenvolvimento sustentável" como o desenvolvimento que "satisfaz as necessidades do presente sem comprometer a capacidade das futuras gerações de satisfazer suas próprias necessidades". Essa definição vaga tem gerado discussões sem fim entre cientistas sociais, a respeito do significado de "futuras gerações".

(José Goldemberg)

Uma crescente preocupação vem surgindo em relação à preservação do meio ambiente, principal afetado pelo contínuo aumento de elementos poluentes e também pela cada vez mais elevada concentração de dióxido de carbono na atmosfera, principal responsável pelo notório efeito estufa. Uma das principais fontes de disseminação desse gás, e de alguns outros cujo efeito é nocivo tanto para o homem quanto para a natureza, são as emissões gasosas provenientes da queima de combustíveis veiculares derivados do petróleo, a mais conhecida e empregada fonte fóssil de energia. Ao serem utilizados para geração de energia mecânica, através de sua combustão, a gasolina e o óleo diesel - principais combustíveis veiculares da atualidade, ambos derivados do petróleo - liberam no ar compostos de enxofre e nitrogênio, assim como carbono, na forma de seu monóxido e dióxido; com o passar dos anos essas substâncias foram se acumulando e modificando - de forma negativa - o meio sócio-ambiental. Ao longo das últimas décadas as preocupações que surgiram acabaram por moldar pensamentos e idéias, levando a novas necessidades que precisariam ser atendidas e, dessa forma, teve início uma constante busca científica por novas tecnologias que fossem, ao mesmo tempo, menos poluentes e comercialmente viáveis de proporcionar energia para o setor de transportes. As inovações tecnológicas são fruto da busca por soluções que procuram atender certas necessidades técnicas, comerciais e, nesse caso, também ambientais, a um custo factível de comercialização, uma vez que os aspectos comerciais têm um papel decisivo no sucesso ou abandono de uma nova idéia pois exercem influência direta ao se definir volumes de recursos financeiros, humanos e científicos que serão alocados para o investimento em um dado esforço tecnológico. Pode-se dizer que as pressões exercidas pela cada vez mais presente legislação ambiental caracteriza um dos 
principais fatores de propulsão de tecnologias inovadoras ou o aperfeiçoamento daquelas já utilizadas ou ainda, a transformação de uma rota tecnológica em outra.

O festejado protocolo estabelecido na cidade japonesa de Kyoto, ao final do ano de 1997 - e posteriormente concluído em 2001 na cidade de Marrakesh - apresenta diretrizes que, por fim, promovem a descarbonização da matriz energética mundial, onde os combustíveis veiculares ocupam uma visada posição por serem primordialmente e majoritariamente produtos derivados do petróleo, a mais notória das fontes fósseis de energia. Apenas a iniciativa dos países industrializados participantes não basta para resultados concretos se não houver a disposição dos meios que viabilizem essa descarbonização e, se for observado, os combustíveis veiculares residem no epicentro do contexto energético mundial, atraindo a atenção de governos, comunidades científicas e acadêmicas, grandes corporações e montadoras de veículos. A disposição desses meios dar-se-á, em muitas das vezes, pela geração de custos que recaiam sobre os combustíveis fósseis, fomentando o conceito, aplicado a prática, dos combustíveis renováveis, promovendo um incentivo significativo para pesquisas que ousem além do que já foi conquistado. Por muitos anos vindouros os pilares do setor de transportes da moderna sociedade ainda haverão de ser sustentados pelos combustíveis líquidos até um tempo onde carros híbridos, por exemplo, ou ainda, modelos mais inovadores como os movidos a ar comprimido, possam representar uma verdadeira revolução para os transportes; enquanto isso, o mundo continuará dependente dos combustíveis líquidos e, se essa não é a alternativa mais desejada, o correto a se fazer é tentar otimizá-la de tal forma que sua dependência e impactos sócio-ambientais - assim como quaisquer outros aspectos negativos associados ao seu uso - possam ser mitigados ao seus extremos pois, afinal de contas, somente porque um novo horizonte tecnológico ainda não se apresenta de forma concreta, não é prudente deixar de aprimorar ao máximo o que se tem. Dentro do cenário energético global surgem, com destaque, os biocombustíveis, cujo principal objetivo é, ao mesmo tempo, oferecer um suporte à cadeia de abastecimento de combustíveis veiculares e mitigar os efeitos danosos decorrentes da maciça utilização de derivados de fontes energéticas fósseis. Os biocombustíveis têm se apresentado como uma alternativa viável de ser utilizada pois são capazes de oferecer a possibilidade de se produzir energia sem um aumento nas emissões do principal gás de efeito estufa, o dióxido de carbono, dado que os vegetais verdes podem fixar o carbono livre na atmosfera, contrário ao que ocorre quando se queima carvão ou um derivado de petróleo - em teoria pode-se dizer que possuem uma emissão neutra de carbono, além de oferecerem uma redução quanto à dependência de petróleo e dessa forma contribuir para uma melhor segurança energética. O universo dos biocombustíveis é composto 
por muitas variáveis que determinam os seus tipos e características, sempre considerando os recursos naturais dos países, o know how empregado e, principalmente, a matéria-prima utilizada para sua obtenção. Pode-se mencionar a conceituada tecnologia de produção do etanol combustível, desenvolvida no Brasil, a partir da cana-de-açúcar; há ainda o mesmo biocombustível produzido nos Estados Unidos da América porém, a partir do milho; já o biodiesel pode ser fabricado a partir de diferentes espécies vegetais oleaginosas e por diferentes processos.

Este estudo aborda os denominados biocombustíveis sintéticos, localizados na atual fronteira tecnológica da energia, distintos dos biocombustíveis tradicionais, tidos como pertences à primeira geração. Sua obtenção é possível através da rota conhecida como Biomass-to-Liquids (BTL) e consiste na utilização do processo de gaseificação para transformar a biomassa em um insumo conhecido como gás de síntese (syngas ou, de forma mais adequada, biosyngas) e sua posterior aplicação na síntese Fischer-Tropsch para obtenção de combustíveis veiculares de boa qualidade e menos poluentes. Torna-se fundamental conceituar a biomassa, elemento primordial para o desenvolvimento da rota BTL; seguir-se-á com a apresentação do processo de gaseificação, seus diferentes tipos de conversão térmica e reações até a produção do versátil gás de síntese que, por sua vez, consiste em mistura gasosa majoritariamente formada por monóxido de carbono $(\mathrm{CO})$ e hidrogênio $\left(\mathrm{H}_{2}\right)$, ponto de partida para outras tecnologias de biocombustíveis. Dada a complexa natureza das inúmeras biomassas que podem ser empregadas, faz-se necessário submeter o biosyngas a um processo de limpeza para remoção de contaminantes e demais substâncias voláteis. Segue-se com o emprego desse insumo produtivo na síntese Fischer-Tropsch que, por sua vez, é introduzida por uma abordagem histórica para um entendimento mais amplo, seguida pela introdução de seu conceito fundamental - a "construção" de cadeias de hidrocarbonetos - e seus principais mecanismos de operação e catalisadores. Os produtos obtidos serão, cada um em sua proporção, direcionados para o uso final mais adequado que lhes couber. O foco será para gasolina e óleo diesel, dada sua notoriedade e importância no mercado mundial de combustíveis e, para tal, uma abordagem do termo combustível tornar-se-á importante, assim como uma caracterização histórica dos combustíveis fósseis e suas principais vertentes, até a chegada dos biocombustíveis sintéticos da primeira e da segunda geração, objetivo desse estudo que, por fim, pretende apontar as reconhecidas qualidades dos produtos da rota BTL, uma promissora tecnologia. 


\section{GASEIFICAÇÃO DE BIOMASSA}

As a result of environmental and other policy considerations, there is increasing world-wide interest in the use of biomass resources as feedstocks for producing power, fuels, and chemicals...Biomass gasification technologies are expected to be an important part of the effort to meet these goals of expanding the use of biomass...Gasification offers a combination of flexibility, efficiency, and environmental acceptability that is essential in meeting future energy requirements.

(Don J. Stevens)

\subsection{Conceituando biomassa}

Probstein e Hicks (1982) e Klass (1998) definem biomassa como qualquer material derivado da vida vegetal e que seja renovável em um período de tempo inferior a 100 anos. A maioria dos recursos energéticos como o petróleo, carvão mineral, xistos betuminosos e querogênio são, de fato, derivados da vida vegetal mas não são considerados renováveis. São considerados como biomassa os detritos florestais e aqueles provenientes da agricultura e processos industriais (serrarias, indústrias moveleiras), assim como as algas, caracterizadas como biomassa virgem aquática; detritos animais também são tidos como biomassa uma vez que eles são derivados de plantas que foram consumidas como alimento. Higman e van der Burgt (2003) definem, de forma abrangente, a biomassa como sendo qualquer combustível ou matéria bruta derivados de organismos que estiveram vivos recentemente. Tal definição claramente exclui os tradicionais combustíveis fósseis que, mesmo tendo sido derivados de matéria orgânica vegetal e animal, foram precisos milhões de anos para sua conversão na forma que são encontrados atualmente. Com exceção de algumas microalgas e matérias com altos índices de umidade a biomassa se caracteriza, essencialmente, por ser uma matéria carbonada em estado sólido.

Assim como nos combustíveis convencionais, a energia contida na biomassa é energia química associada com os átomos de carbono e hidrogênio contidas nas moléculas orgânicas 
oxidáveis. A fonte do carbono e do hidrogênio é o dióxido de carbono e a água. Ambas as substâncias são, de fato, produtos de combustão e não fontes de energia propriamente ditas. A conversão do dióxido de carbono e da água, pelas plantas, para uma forma de combustível orgânico, ocorre pelo processo conhecido como fotossíntese, sendo que os dois ingredientes indispensáveis para tal são a energia solar e a clorofila. A clorofila, uma complexa substância presente nas células das plantas verdes, absorve a energia solar e a torna disponível para a fotossíntese, a qual pode ser representada pela equação química geral:

$\mathrm{nCO}_{2}+\mathrm{mH}_{2} \mathrm{O}+$ luz solar e clorofila $\rightarrow \mathrm{C}_{\mathrm{n}}\left(\mathrm{H}_{2} \mathrm{O}\right)_{\mathrm{m}}+\mathrm{nO}_{2} \quad \Delta \mathrm{H}=+470 \mathrm{~kJ} \mathrm{~mol}^{-1}$ Reação (2.1)

Na reação (2.1) o termo $\mathrm{C}_{\mathrm{n}}\left(\mathrm{H}_{2} \mathrm{O}\right)_{\mathrm{m}}$ é usado para representar uma classe de compostos orgânicos conhecidos como carboidratos, muitos dos quais têm origem no decorrer da reação. Cerca de um quarto do total produzido de carboidratos é consumido no processo de respiração do vegetal e o restante é armazenado. As plantas contêm cerca de $0,1 \%$ a 3,0\% da energia solar incidente original, a qual é uma medida da energia máxima recuperável da planta se convertida em um combustível sintético. Parte dessa energia pode, contudo, ser degradada pela formação de produtos intermediários e haverão, de fato, perdas associadas à conversão da biomassa em um combustível tradicional. Ushima (2004) reafirma que a biomassa pode ser tida como uma fonte natural de energia pois armazena a energia solar através da reação de fotossíntese, tendo como principais componentes a hemicelulose, a lignina e a celulose (composição média: $\mathrm{C}_{6} \mathrm{H}_{10} \mathrm{O}_{5}$ ), variando pouco, dependendo de sua natureza. É válido destacar ainda que, segundo Karayildirim; Sinağ e Kruse (2008) a biomassa apresenta em sua composição diversos sais e outros constituintes minerais que podem influenciar em suas reações de conversão térmica para aproveitamento de sua energia. Como exemplo, Andrade et al. (2007) explicam que os sais dióxido de silício e o óxido de potássio, presentes na casca do arroz, quando em temperaturas superiores a $850^{\circ} \mathrm{C}$ se fundem formando pequenas barras de material vítreo (sinterização). Outra definição, semelhante às supracitadas, é apresentada por Nogueira e Lora apud Sales; Andrade e Lora (2005) onde se pode considerar a biomassa, de forma mais abrangente, como sendo todo material de origem orgânica, como por exemplo, a madeira, detritos animais e resíduos orgânicos, sendo de grande interesse os resíduos agrícolas como a casca de arroz, a serragem e o bagaço da cana-de-açúcar usado para cogeração nas usinas sucro-alcooleiras.

Atualmente os chamados combustíveis fósseis representam cerca de $80,1 \%$ do suprimento de energia no mundo; $6,3 \%$ provém do uso de fontes nucleares e 13,6\% do uso de 
energias renováveis, sendo que a maior parte $(8,5 \%)$ provém da chamada biomassa tradicional (lenha) caracterizada, principalmente, por sua utilização ineficiente em fornos de cozinhas primitivos, que são poluentes, utilizados por populações rurais o que, em muitos dos casos, acaba por acarretar em desflorestamento. Ao se referir à biomassa moderna entende-se como sendo aquela produzida de uma forma sustentável e utilizada para geração de eletricidade, produção de calor (na co-geração, por exemplo) e combustíveis líquidos veiculares. Podem ser englobados nessa divisão os resíduos vegetais e florestais de reflorestamento e/ou manejo sustentável assim como os resíduos da pecuária e agricultura e resíduos urbanos (efluentes líquidos, por exemplo). A biomassa moderna está incluída nas "novas fontes renováveis de energia" que, juntas, totalizam cerca de 16 exajoules $\left(16 \times 10^{18} \mathrm{~J}\right)$, o que equivale a $3,4 \%$ do total de energia gerada no mundo conforme demonstrado na figura (2.1) com dados publicados pela revista Science (2007).

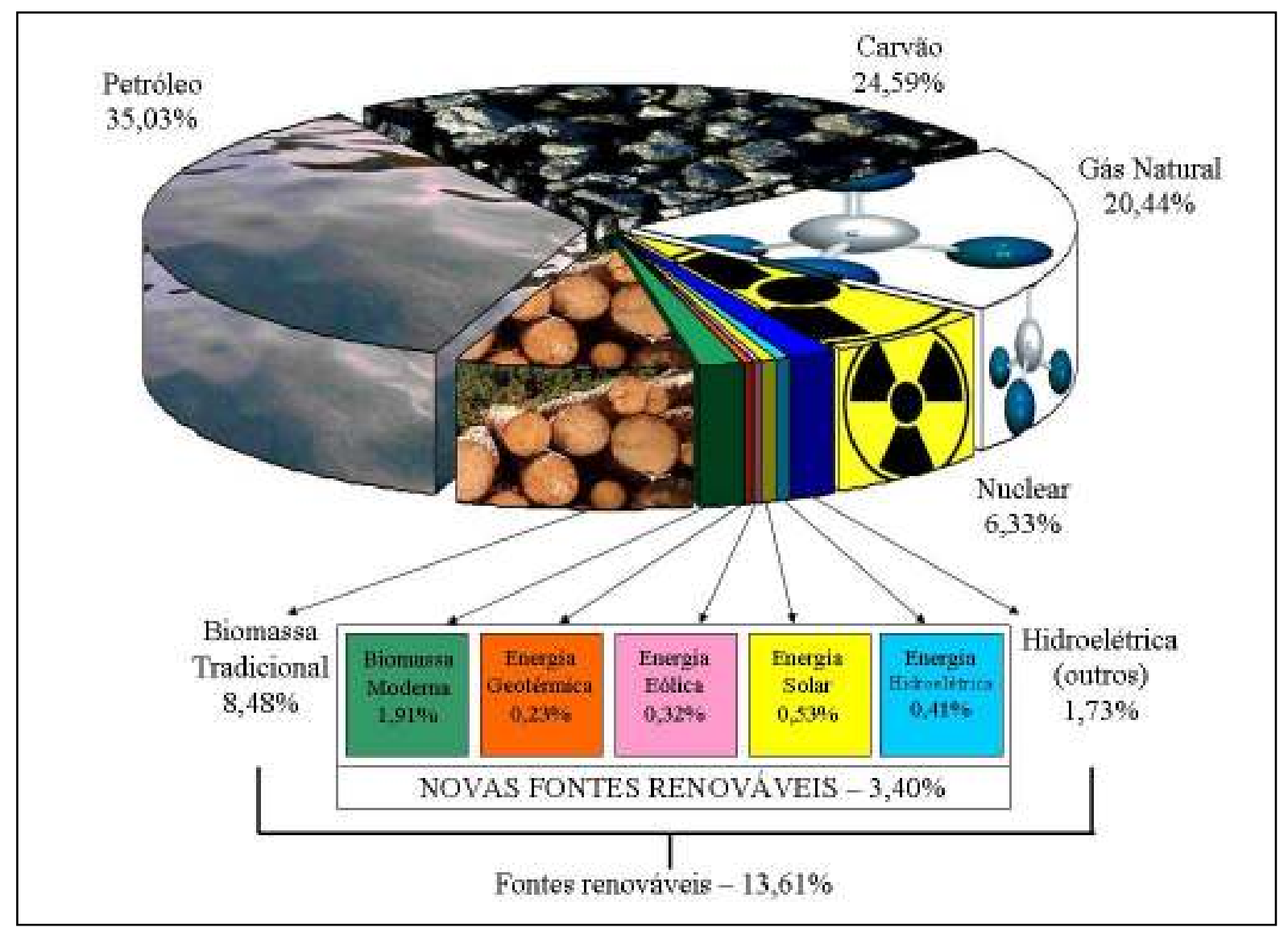

Figura 2.1 Distribuição das fontes de energia na atualidade

Fonte: (informação online) ${ }^{1}$; Adaptado. 
Ainda segundo Nogueira e Lora apud Sales; Andrade e Lora (2005) atualmente são de grande interesse as florestas energéticas e os resíduos agrícolas pois, conforme dados provenientes do Balanço Energético Nacional - BEN (BRASIL, 2005), no país cerca de $43,9 \%$ da oferta interna de energia é oriunda das chamadas fontes renováveis, enquanto que no mundo esse valor é de $13,61 \%$ e nos países desenvolvidos é de apenas $6 \%$. Os 56,1\% restantes são de fontes fósseis (petróleo, carvão mineral e gás natural).

Ao ser aplicada em processos industriais, para recuperação de sua energia potencial, de acordo com Piffer (1999), a biomassa se apresenta em variadas formas e dado esse fato é incorreto e simplista afirmar que determinado equipamento pode gaseificar qualquer combustível de biomassa, desta forma sendo imprescindível se conhecer suas propriedades para determinar as condições satisfatórias de operação de gaseificação. Análises são capazes de determinar, mesmo que de forma aproximada, a presença de umidade, materiais voláteis, cinzas e o carbono fixo da amostra e uma análise química lista a presença e quantidade de outros elementos como o hidrogênio, oxigênio, nitrogênio, enxofre, dentre outros. Deve ser observado também que algumas formas de biomassa podem não ser adequadas para determinados tipos de gaseificadores, sendo requeridos processos de acondicionamento como a densificação, por exemplo, assim como a etapa de secagem - compreendida numa faixa de temperatura entre $60^{\circ} \mathrm{C}$ e $80^{\circ} \mathrm{C}$ - responsável pela melhora na qualidade do gás que será obtido, assim como uma redução no teor de alcatrões. A umidade presente pode estar presente em meio às fibras vegetais ou de forma superficial; pode estar quimicamente combinada presente na própria estrutura química da madeira, por exemplo, e correspondendo a aproximadamente $46 \%$ do peso dela seca.

O uso correto da biomassa moderna poderá significar uma considerável fonte de energia nos anos vindouros; energia esta, menos poluente se comparada às tradicionais fontes fósseis e também considerada ecologicamente aceitável dadas as suas principais características: sustentabilidade e renovabilidade. Muitas são as tecnologias que procuram recuperar e/ou converter a energia latente contida em uma quantidade da ordem de dois trilhões de toneladas de biomassa produzidas anualmente - o que significa algo em torno de 400 toneladas per capita e isso corresponde a mais de $3.000 \mathrm{EJ}$, o equivalente a oito vezes o consumo mundial de energia (RAMAGE; SCURLOCK apud BOYLE, 1996).

\footnotetext{
1 Material extraído do artigo "Etanol para um futuro energético sustentável" de autoria do prof. ${ }^{\text {o Dr. José }}$ Goldemberg, disponível no website da Universidade de São Paulo (USP) na sessão "Jornal da USP" disponível em $<$ http://www.usp.br/jorusp/arquivo/2007/jusp794/pag02.htm> Acesso em 10.ago.2008
} 


\subsection{Introdução aos processos de gaseificação de biomassa}

Segundo Higman e van der Burgt (2003) o primeiro combustível utilizado pelos seres humanos foi a lenha - e ainda é utilizado até os dias atuais para variados fins, incluindo a produção de carvão vegetal para processos industriais. Embora a fabricação do carvão vegetal já fosse conhecida há muito tempo foi somente na segunda metade do século 18 que sua produção esteve em evidência no país que tornar-se-ia o berço da revolução industrial: a Inglaterra. Em 1812, com a fundação da London Gas, Light and Coke Company, a produção de um certo gás, que era obtido através da passagem de vapor de água por carvão incandescente, tornou-se um processo comercial. Esse gás se tornou o mais importante combustível gasoso utilizado no começo do século 19, sendo composto majoritariamente por monóxido de carbono $(\mathrm{CO})$ e hidrogênio $\left(\mathrm{H}_{2}\right)$, e foi utilizado inicialmente como fonte de iluminação, seguido pela geração de calor e posteriormente como matéria-prima à indústria química. A princípio sua produção era custosa pelo processo de gaseificação e por esse motivo muitas pessoas o utilizavam apenas para iluminação e cozimento pois apresentava grandes vantagens se comparado ao carvão ou ao uso de velas. No decorrer do século 20 seus usos foram mudando e se adequando às necessidades de cada época - próximo a 1900 deixou de ser usado para iluminação com o advento das lâmpadas de bulbo - e posteriormente seria usado como insumo no processo Fischer-Tropsch para a síntese de hidrocarbonetos e também na fabricação do ácido acético anidro.

Na década de 1920, o alemão Carl Paul Gottfried von Linde (1842-1934) tornou comercial o processo de separação criogênica do ar, o que viabilizou a produção de gás de síntese $\left(\mathrm{CO}+\mathrm{H}_{2}\right)$ ou hidrogênio utilizando-se o oxigênio puro como agente oxidante. Essa época foi de grande relevância para os processos de gaseificação pois foram desenvolvidos importantes processos que tornar-se-iam os precursores de muitas unidades de gaseificação da atualidade: o processo Winkler de leito-fluidizado (1926); o processo de gaseificação pressurizada de Lurgi (1931) e o processo Koppers-Totzek (1940). Com os passar dos anos as tecnologias de gaseificação tiveram um papel importante durante a II Guerra Mundial, principalmente, na Alemanha, para produção de combustíveis sintéticos e síntese da amônia. Mais de um milhão de gaseificadores de pequeno porte, para madeira ou carvão vegetal, foram construídos durante esse período histórico para gerar gases combustíveis que seriam usados em veículos adequados e também na geração de energia elétrica. Os gaseificadores eram encontrados em muitos modelos e adaptados aos veículos ou fornalhas para sua queima. 
Klass (1998) aponta que, somente na Suécia, em meados de 1945, havia cerca de 70.000 unidades veiculares, dentre caminhões e ônibus, em operação, do tipo "GENGAS"2. $\mathrm{Na}$ América do Norte, Europa e Ásia muitas pesquisas continuaram a desenvolver inovações para os processos de gaseificação de biomassa ao longo das décadas. Muitos gaseificadores, originalmente projetados para operar com carvão vegetal, acabaram sendo utilizados com biomassa, uma vez que a química envolvida na gaseificação do carvão é semelhante àquela presente na gaseificação da biomassa contudo, a biomassa é muito mais reativa do que a maioria dos carvões por conter mais matéria volátil.

Posteriormente veio a tecnologia da reforma a vapor do gás natural e já na década de 50 foram desenvolvidos processos de gaseificação de óleo pesado pelas companhias Texaco e Shell, que seriam usados em locais com escassez de gás natural. Na década de 70, com a primeira crise do petróleo, os processos de gaseificação do carvão voltaram a ser utilizados para produção de combustíveis líquidos e gasosos. Nos anos vindouros, consideráveis investimentos foram feitos para o desenvolvimento de novas tecnologias, assim como grandes empresas realizaram parcerias e desenvolveram processos mais eficientes. Já nos anos 80, com a renovada oferta do petróleo, o interesse na gaseificação e liquefação do carvão enfrentou uma redução e muito do desenvolvimento tornou-se lento.

Num sentido amplo Higman e van der Burgt (2003) apresentam o termo gaseificação como a conversão de qualquer hidrocarboneto combustível para um produto em estado gasoso com um poder calorífico passível de utilização, diferenciando-se assim da combustão, por essa produzir um gás residual que não possui poder calorífico. Os processos de gaseificação da biomassa caracterizam-se, comumente, por produzirem gases combustíveis de baixo ou médio poder calorífico, gás de síntese (synthesis gas ou syngas ou ainda biosyngas) para manufatura de produtos da indústria química ou ainda produzirem hidrogênio.

Probstein e Hicks (1982) indicam que os processos térmicos oferecem os meios mais efetivos de recuperar ou converter a energia armazenada na madeira e em outras biomassas lignocelulósicas e assim fazer uso dela. Em se tratando da gaseificação da biomassa, um ou mais reagentes podem ser introduzidos no sistema. Esses reagentes irão se combinar com o carbono sólido presente na estrutura da biomassa, em altas temperaturas, enquanto o consomem.

\footnotetext{
2 GENGAS se refere ao manual "Gengassidan", desenvolvido por Harry LaFontaine, durante o período da II Guerra Mundial, à pedido da FEMA (Federal Emergency Management Agency). O manual continha instruções para a adaptação de gaseificadores de biomassa ou carvão vegetal aos veículos da época. Pode-se encontrar sua versão online em: <http://www.gengas.nu/byggbes/index.shtml $>$
} 
Ao se gaseificar biomassa a quantidade de material carbonado remanescente é muito baixa e as pequenas porções de alcatrões e demais óleos gerados como subprodutos podem ser reciclados posteriormente ou eliminados em sistemas de limpeza de gases e material particulado. Bridgwater apud Sales; Andrade e Lora (2005) definem a gaseificação da biomassa como uma conversão térmica em uma mistura gasosa (combustível) na presença de um agente oxidante. Andrade et al. (2007) definem que nessa conversão em gás de gaseificação haja, comumente, como principais componentes, o monóxido de carbono, hidrogênio, metano e água em forma de vapor - principais responsáveis pela determinação de seu poder calorífico; ainda há o nitrogênio e o dióxido de carbono que são considerados inertes e a presença de traços de hidrocarbonetos de baixo peso molecular como o eteno, o etano e o propeno; bem como alcatrão e particulados (SALES; ANDRADE; LORA, 2005).

Apolinario (2006) aponta que a composição do gás pode variar de acordo com diversos fatores, tais como o modelo de forno de gaseificação que será utilizado, a forma como a energia será fornecida ao processo, a injeção ou não de vapor de água junto ao agente oxidante - seja ele ar ou oxigênio puro -, o tempo de retenção da carga de biomassa, o sistema de coleta dos gases e dos demais produtos (cinzas) e também do tipo da matéria carbonada utilizada, dado que, dentre as muitas possibilidades (bagaço de cana-de-açúcar, cavacos de madeira, palha de milho, cascas de arroz, serragem, resíduos agrícolas diversos, etc.) cada espécie apresenta diferentes composições, conforme indicado nas tabelas (2.1) e (2.2).

Tabela 2.1 Composição elementar (\%) de diferentes tipos de biomassa

\begin{tabular}{|c|c|c|c|c|c|c|c|}
\hline \multirow[b]{2}{*}{ Tipo de Biomassa } & \multicolumn{7}{|c|}{ Composição Elementar (\%) } \\
\hline & $\begin{array}{c}\text { Carbono } \\
\text { (C) }\end{array}$ & $\begin{array}{c}\text { Hidrogênio } \\
(\mathrm{H}) \\
\end{array}$ & $\begin{array}{c}\text { Oxigênio } \\
\text { (O) }\end{array}$ & $\begin{array}{l}\text { Nitrogênio } \\
\text { (N) }\end{array}$ & $\begin{array}{c}\text { Enxofre } \\
\text { (S) }\end{array}$ & Cinzas & Outros \\
\hline Bagaço de cana & 44,80 & 5,30 & 42,30 & 0,38 & 0,01 & 1,50 & 5,71 \\
\hline Casca de arroz & 40,90 & 4,30 & 35,80 & 0,40 & 0,02 & 18,30 & 0,28 \\
\hline Casca de cóco & 48,20 & 5,20 & 33,10 & 2,98 & 0,12 & 10,25 & 0,15 \\
\hline Eucalipto & 49,00 & 5,80 & 43,90 & 0,03 & 0,01 & 0,72 & 0,54 \\
\hline Pinus (genero) & 49,20 & 5,90 & 44,30 & 0,06 & 0,03 & 0,30 & 0,21 \\
\hline Ramas de algodão & 47,00 & 5,30 & 40,70 & 0,65 & 0,21 & 5,89 & 0,25 \\
\hline Sabugo de ruilho & 46,50 & 5,80 & 45,40 & 0,47 & 0,01 & 1,40 & 0,42 \\
\hline
\end{tabular}

Fonte: (Adaptado de BIZZO, 2007). 
Tabela 2.2 Propriedades de diversas variedades de biomassas

\begin{tabular}{|c|c|c|c|c|c|}
\hline Biomassa & $\begin{array}{c}\mathrm{PCS} \\
\mathrm{MJ} / \mathrm{kg}\end{array}$ & $\begin{array}{c}\text { Umidade } \\
\% \text { (base úmida) }\end{array}$ & $\begin{array}{c}\text { Cinzas } \\
\% \text { (base úmida) } \\
\end{array}$ & $\begin{array}{l}\text { Enxofre (S) } \\
\% \text { (base seca) } \\
\end{array}$ & $\begin{array}{l}\text { Cloro }(\mathrm{Cl}) \\
\% \text { (base seca) }\end{array}$ \\
\hline Bagaço de cana & $8-10$ & $40-60$ & $1-4$ & & \\
\hline Carvão vegetal & $25-32$ & $1-10$ & $0,5-6$ & & \\
\hline Cascas de amendoim & 17 & $2-3$ & 10 & & \\
\hline Cascas de arroz & $13-14$ & $9-15$ & $15-20$ & & \\
\hline Cascas de cacau & $13-16$ & $7-9$ & $7-14$ & & \\
\hline Cascas de côco & $18-19$ & $8-10$ & $1-4$ & & \\
\hline Caules de algodão & 16 & $10-20$ & 0,1 & & \\
\hline Madeira & $10-20$ & $10-60$ & $0,25-1,7$ & 0,01 & 0,01 \\
\hline Palha & $14-16$ & 10 & $4-5$ & 0,07 & 0,49 \\
\hline Palha de soja & $15-16$ & $8-9$ & $5-6$ & & \\
\hline Resíduos de óleo de palma & 15 & 15 & & & \\
\hline Serragem & 11,3 & 35 & 2 & & \\
\hline Talos de milho & $13-15$ & $10-20$ & $3-7$ & 0,05 & 1,48 \\
\hline
\end{tabular}

Fonte: (Adaptado de ARBON; QUAAK; KNOEF; STASSEN apud HIGMAN; VAN DER BURGT, 2003).

Higman e van der Burgt (2003) afirmam que as propriedades da biomassa são tão diversas quanto suas origens. As propriedades da biomassa que apresentam uma relevância significativa nos processos de conversão térmica são: sua comumente alta umidade, baixa densidade energética e a presença de oxigênio e hidrogênio dada a alta concentração de compostos voláteis. A presença de hidrogênio e oxigênio aumenta o rendimento dos gases no processo de pirólise, assim como a formação de água. Em alguns gaseificadores a água pode ter uma participação maior nas reações envolvendo os gases formados e dependendo do agente oxidante utilizado pode contribuir para a diminuição do poder calorífico do gás conforme o ar é injetado para alimentar o calor responsável pela evaporação da água (secagem da biomassa), injetando, conseqüentemente, mais nitrogênio no sistema. Os gases de pirólise podem ser deficientes em hidrogênio - dada a formação de água em forma de vapor - e os líquidos gerados são altamente oxigenados como os alcatrões. (PROBSTEIN; HICKS, 1982).

É apontado por Hamelinck et al. (2003) que antes de qualquer processo de gaseificação a biomassa deve passar por um pré-tratamento que consiste em muitas etapas, como secagem e redução de tamanho, antes da alimentação do gaseificador. Para evitar a auto-ignição ou explosão dos pellets de biomassa ao entrarem no gaseificador é necessária a injeção de algum agente inerte como o nitrogênio, o dióxido de carbono ou vapor de água (somente em gaseificadores atmosféricos). Para a secagem da biomassa uma certa quantidade 
de energia é necessária e de acordo com den Uil et al.; Hamelinck et al.; Tijmensen et al.; Faaij et al.; van Ree et al. apud Hamelinck (2003) a eficiência do processo de gaseificação aumenta quando a biomassa apresenta baixos índices de umidade; contudo a quantidade de hidrogênio tende a diminuir o que pode ser desfavorável para seu uso na síntese FischerTropsch.

Klass (1998), Reed e Das apud Piffer (1999) indicam que, dentre os processos de gaseificação existem, basicamente, três tipos distintos, são eles: a pirólise, a oxidação parcial e a gaseificação a vapor ou reforma a vapor. A combustão também é mencionada, contudo a mesma não gera um gás cujo poder calorífico possa ser aproveitado. Tanto a pirólise quanto a gaseificação e a combustão podem ocorrer simultaneamente dentro de um gaseificador. Usando-se a unidade monomérica da celulose $\left(\mathrm{C}_{6} \mathrm{H}_{10} \mathrm{O}_{5}\right)$ para representar a biomassa nas reações adiante pode-se estimar quais seriam as possibilidades estequiométricas das reações de gaseificação conforme o processo de conversão térmica escolhido. Karayildirim; Sinağ e Kruse (2008) apontam que a celulose é o polímero natural mais abundante no mundo e que, em termos de composição final do gás de gaseificação produzido a partir dela, o mesmo é semelhante ao produzido por biomassas propriamente utilizadas.

\subsubsection{Conversão térmica: Pirólise}

Segundo Probstein e Hicks (1982) o processo de conversão térmica conhecido como pirólise caracteriza-se pela decomposição da matéria orgânica através do calor, na ausência de oxigênio e, normalmente, outros reagentes químicos não são utilizados; contudo, em se tratando da gaseificação, pode-se introduzir no sistema certas quantidades de hidrogênio, oxigênio e vapor de água. Dado o processo de gaseificação da biomassa, que ocorre a elevadas temperaturas, a pirólise pode ser considerada como sendo o primeiro estágio nesse processo de conversão. Mesa et al. (2003) justificam que por ser uma complexa mistura de polímeros naturais (celulose, hemicelulose e lignina) e outras substâncias (extrativos e cinzas), a composição da biomassa lignocelulósica apresenta um importante papel na distribuição dos produtos de pirólise. Cada biomassa apresenta uma característica particular ao ser pirolisada devido à proporção dos diferentes componentes que as constituem.

De acordo com Klass (1998) e Lora (2008) os produtos primários obtidos pela pirólise da biomassa são gases, óleos, carvão e água. A fração resultante de cada produto depende da 
temperatura e pressão no gaseificador e do tempo de residência da biomassa no mesmo. Desta forma, existem diferentes tipos de processos pirolíticos, como por exemplo a pirólise rápida, a pirólise a vácuo, entre outros, e conforme a temperatura do processo aumenta, também aumenta o rendimento dos gases. É válido destacar que a formação de água independe se a biomassa utilizada tenha sofrido ou não um processo de pré-secagem. Uma vez que a água está contida em forma de umidade na biomassa, ela é liberada conforme a mesma vai secando no gaseificador e também em decorrências das reações químicas que tomam lugar. Se não for removida ela irá participar das demais reações químicas, juntamente com água ou vapor que por ventura venham a ser inseridos como parte dos reagentes.

Probstein e Hicks (1982) apontam que os produtos resultantes da gaseificação da biomassa podem variar de acordo com as propriedades da mesma, ou com a taxa de aquecimento dentro do gaseificador e também com a temperatura final atingida. Um processo pirolítico lento pode produzir maior quantidade de material carbonado, enquanto um processo cuja taxa de aquecimento é alta o rendimento de produtos líquidos e gasosos é maior. A pirólise em ambiente rico em hidrogênio - conhecida como hidropirólise - aumenta a formação de material carbonado mas também produz maiores quantidades de líquidos de melhor qualidade. Durante o processo de pirólise, os reagentes adicionados se combinam com o carbono sólido em temperaturas elevadas, aumentando o rendimento dos gases à medida que consome o material carbonado. A seguir, reações que procuram descrever as combinações que por ventura venham a ocorrer num processo pirolítico utilizando-se a biomassa:

$$
\begin{array}{lr}
\mathrm{C}_{6} \mathrm{H}_{10} \mathrm{O}_{5} \rightarrow 5 \mathrm{CO}+5 \mathrm{H}_{2}+\mathrm{C} & \text { Reação (2.2) } \\
\mathrm{C}_{6} \mathrm{H}_{10} \mathrm{O}_{5} \rightarrow 5 \mathrm{CO}+\mathrm{CH}_{4}+3 \mathrm{H}_{2} & \text { Reação (2.3) } \\
\mathrm{C}_{6} \mathrm{H}_{10} \mathrm{O}_{5} \rightarrow 4 \mathrm{CO}+\mathrm{CH}_{4}+\mathrm{C}+2 \mathrm{H}_{2}+\mathrm{H}_{2} \mathrm{O} & \text { Reação (2.4) } \\
\mathrm{C}_{6} \mathrm{H}_{10} \mathrm{O}_{5} \rightarrow 5 \mathrm{CO}+\mathrm{CH}_{4}+3 \mathrm{H}_{2} & \text { Reação (2.5) } \\
\mathrm{C}_{6} \mathrm{H}_{10} \mathrm{O}_{5} \rightarrow 3 \mathrm{CO}+\mathrm{CH}_{4}+2 \mathrm{C}+\mathrm{H}_{2}+2 \mathrm{H}_{2} \mathrm{O} & \text { Reação (2.6) } \\
\mathrm{C}_{6} \mathrm{H}_{10} \mathrm{O}_{5} \rightarrow 2 \mathrm{CO}+\mathrm{CO}_{2}+2 \mathrm{CH}_{4}+\mathrm{C}+\mathrm{H}_{2} \mathrm{O} & \text { Reação (2.7) }
\end{array}
$$


É apontado por Alpert et al., Bailie, Paisley, Feldmann e Appelbaum apud Klass (1998) que o processo mais relevante de gaseificação pirolítica da biomassa é o sistema de leito fluidizado de aquecimento indireto. Este sistema utiliza dois reatores de leito fluidizado contendo areia como mediador para a transferência de calor. A combustão do carvão formado no reator de pirólise ocorre na presença de ar no interior do reator de combustão. A transferência de calor é possível dada a diferença de temperatura que flui pela areia quente do reator de combustão a $950{ }^{\circ} \mathrm{C}$ para o reator de pirólise a $800{ }^{\circ} \mathrm{C}$ e depois o retorno dessa areia para o primeiro reator. Esse tipo de configuração separa as reações de combustão das reações de pirólise, assim como mantém o nitrogênio presente no ar (considerando que se esteja utilizando o ar como agente oxidante) separado do gás gerado na pirólise. Esse gás pode sofrer um processo de aprimoramento para um gás de alta energia podendo substituir o gás natural, por exemplo; contudo, o propósito aqui desejado é a produção do gás de síntese para o processo Fischer-Tropsch.

\subsubsection{Conversão térmica: Oxidação parcial}

Muitos processos de conversão térmica podem ser considerados como sendo processo de oxidação parcial onde é suprido para biomassa uma quantidade de ar ou oxigênio inferior àquela estequiometricamente ideal para a combustão completa da mesma. Quando o oxigênio é fornecido através do ar atmosférico o gás formado possui uma baixa energia por conter altas concentrações de hidrogênio, monóxido e dióxido de carbono; já quando o oxigênio é fornecido puro, ou mesmo ar enriquecido com ele, o gás obtido possui um poder calorífico maior. O reator que comporta esse processo pode ser dividido em zonas distintas: uma zona de combustão que fornece calor para uma segunda zona, a de pirólise e ainda para uma terceira zona, a de secagem. Segundo Fisher; Kasbohm and Rivero apud Klass (1998) um sistema para a gaseificação pela oxidação parcial da biomassa pode usar um reator vertical dividido em três zonas onde a biomassa é alimentada pelo topo do mesmo e, conforme desce pelo gaseificador, esta sofre uma secagem dados os gases quentes ascendentes - a temperatura do mesmo passa de cerca de $315^{\circ} \mathrm{C}$ para uma faixa que varia de $40{ }^{\circ} \mathrm{C}$ a $200{ }^{\circ} \mathrm{C}$. A biomassa seca entra na zona de pirólise na qual a faixa de temperatura situa-se entre $315^{\circ} \mathrm{C}$ a $1000{ }^{\circ} \mathrm{C}$. O carvão e as cinzas resultantes seguem de forma descendente para a região da fornalha onde o carvão é parcialmente oxidado. Nessa região a temperatura é próxima dos $1650{ }^{\circ} \mathrm{C}$ e a 
presença de escórias derretidas de óxidos metálicos forma uma concentração líquida no fundo da fornalha. Uma análise típica do gás indica a uma composição aproximada de $40 \%$ de monóxido de carbono, $23 \%$ de dióxido de carbono, $5 \%$ de metano e $20 \%$ de hidrogênio $\left(\mathrm{H}_{2}\right)$. Esse gás possui um poder calorífico próximo a $14,5 \mathrm{MJ} \mathrm{m}^{-3}$. Reações prováveis para um processo de oxidação parcial da biomassa podem ser:

$$
\begin{array}{lr}
\mathrm{C}_{6} \mathrm{H}_{10} \mathrm{O}_{5}+1 / 2 \mathrm{O}_{2} \rightarrow 6 \mathrm{CO}+5 \mathrm{H}_{2} & \text { Reação (2.8) } \\
\mathrm{C}_{6} \mathrm{H}_{10} \mathrm{O}_{5}+\mathrm{O}_{2} \rightarrow 6 \mathrm{CO}+4 \mathrm{H}_{2}+\mathrm{H}_{2} \mathrm{O} & \text { Reação (2.9) } \\
\mathrm{C}_{6} \mathrm{H}_{10} \mathrm{O}_{5}+\mathrm{O}_{2} \rightarrow 5 \mathrm{CO}+\mathrm{CO}_{2}+5 \mathrm{H}_{2} & \text { Reação (2.10) } \\
\mathrm{C}_{6} \mathrm{H}_{10} \mathrm{O}_{5}+2 \mathrm{O}_{2} \rightarrow 6 \mathrm{CO}+2 \mathrm{H}_{2}+3 \mathrm{H}_{2} \mathrm{O} & \\
\mathrm{C}_{6} \mathrm{H}_{10} \mathrm{O}_{5}+1 / 2 \mathrm{O}_{2} \rightarrow 5 \mathrm{CO}+\mathrm{CO}^{2}+5 \mathrm{H}_{2} & \text { Reação (2.11) } \\
\mathrm{C}_{6} \mathrm{H}_{10} \mathrm{O}_{5}+2 \mathrm{O}_{2} \rightarrow 3 \mathrm{CO}+3 \mathrm{CO}_{2}+5 \mathrm{H}_{2} & \text { Reação (2.12) }
\end{array}
$$

\subsubsection{Conversão térmica: Reforma a vapor (gaseificação a vapor)}

Originalmente o termo "reforma" foi empregado para descrever a conversão térmica das frações pesadas do petróleo em produtos mais voláteis, englobando etapas como o craqueamento (craking) e a isomerização, por exemplo. O mesmo termo também descrevia a conversão de hidrocarbonetos gasosos e compostos orgânicos vaporizados para gases ricos em hidrogênio, como o gás de síntese. Klass (1998) aponta que, no que tange a biomassa como matéria-prima, "reforma" se refere ao processo de gaseificação na presença de outro reagente. Exemplos de gaseificação de biomassa por reforma são a reforma a vapor (gaseificação a vapor, pirólise a vapor), a reforma vapor-oxigênio e a reforma vapor-ar. O processo de reforma a vapor envolve reações entre a biomassa e o vapor, assim como os produtos formados dessa reação. A gaseificação de biomassa por reforma a vapor-oxigênio ou vapor-ar inclui a combustão de material carbonado residual do gaseificador, tal como a combustão de 
parte do gás gerado e parte da biomassa para a geração de calor. Esses processos podem ser realizados com ou sem a presença de um catalisador. Uma vez obtido o gás de gaseificação de biomassa, sua energia pode variar. Gases que possuam um poder calorífico (PC) oscilante entre 3,92 a 11,27 $\mathrm{MJ} \mathrm{Nm}^{-3}$ podem ser considerados como gases de baixa energia e são geralmente formados quando há contato direto da biomassa com o ar, ocasionando a diluição dos gases de processo com o nitrogênio presente, dando assim sua diluição. Quando há gaseificação de biomassa na presença de oxigênio puro $\left(\mathrm{O}_{2}\right)$ a presença do nitrogênio é eliminada e o poder calorífico situa-se entre 11,78 e 27,48 $\mathrm{MJ} \mathrm{Nm}^{-3}$. Gases com poder calorífico elevado, entre 27,48 e 39,26 $\mathrm{MJ} \mathrm{Nm}^{-3}$, podem ser obtidos quando as condições estabelecidas ao processo de gaseificação promovem a formação do metano e outros hidrocarboneto de baixo peso molecular; ou ainda quando há um processo pós-gaseificação onde os gases resultantes sofrem um processo de concentração dos gases combustíveis presentes. As prováveis reações para um processo de gaseificação a vapor podem ser:

$$
\begin{array}{lr}
\mathrm{C}_{6} \mathrm{H}_{10} \mathrm{O}_{5}+\mathrm{H}_{2} \mathrm{O} \rightarrow 6 \mathrm{CO}+6 \mathrm{H}_{2} & \text { Reação (2.14) } \\
\mathrm{C}_{6} \mathrm{H}_{10} \mathrm{O}_{5}+2 \mathrm{H}_{2} \mathrm{O} \rightarrow 5 \mathrm{CO}+\mathrm{CO}_{2}+7 \mathrm{H}_{2} & \text { Reação (2.15) } \\
\mathrm{C}_{6} \mathrm{H}_{10} \mathrm{O}_{5}+3 \mathrm{H}_{2} \mathrm{O} \rightarrow 4 \mathrm{CO}+2 \mathrm{CO}_{2}+8 \mathrm{H}_{2} & \text { Reação (2.16) } \\
\mathrm{C}_{6} \mathrm{H}_{10} \mathrm{O}_{5}+7 \mathrm{H}_{2} \mathrm{O} \rightarrow 6 \mathrm{CO}_{2}+12 \mathrm{H}_{2} & \text { Reação (2.17) } \\
\mathrm{C}_{6} \mathrm{H}_{10} \mathrm{O}_{5}+\mathrm{H}_{2} \mathrm{O} \rightarrow 4 \mathrm{CO}+\mathrm{CO}_{2}+\mathrm{CH}_{4}+4 \mathrm{H}_{2} & \text { Reação (2.18) } \\
\mathrm{C}_{6} \mathrm{H}_{10} \mathrm{O}_{5}+\mathrm{H}_{2} \mathrm{O} \rightarrow 2 \mathrm{CO}+2 \mathrm{CO}_{2}+2 \mathrm{CH}_{4}+2 \mathrm{H}_{2} & \text { Reação (2.19) }
\end{array}
$$

Algumas unidades de gaseificação misturam o ar atmosférico com o vapor d água promovendo reações endotérmicas formando assim hidrogênio e monóxido de carbono. Processos de gaseificação desse tipo foram comuns no século passado onde gaseificadores eram empregados para gerar gases de poder calorífico próximo a 5,9 $\mathrm{MJ} \mathrm{Nm}^{-3}$ a partir de biomassa. A energia do gás obtido representava cerca de $70 \%$ da matéria orgânica vegetal alimentada (KLASS, 1998).

Estudos documentados por Antal apud Klass (1998) apontam que a gaseificação da biomassa em um aparato reformador do tipo pirólise-vapor demonstrou que a gaseificação 
ocorre em duas etapas dentro do processo: numa faixa de temperatura compreendida entre 300 ${ }^{\circ} \mathrm{C}$ e $500{ }^{\circ} \mathrm{C}$ os componentes voláteis são liberados da biomassa e algum carvão residual é formado; uma vez que a temperatura esteja próxima a $600{ }^{\circ} \mathrm{C}$ os componentes voláteis são convertidos, via reforma a vapor, ao chamado gás de síntese. Produtos condensáveis como o alcatrão, óleos e piches são reduzidos pelas reações da reforma a vapor para menos de $10 \%$ do total da biomassa alimentada. Conforme a temperatura e o tempo de permanência da biomassa aumentam, também aumenta o rendimento do gás e diminui a quantidade de carvão e alcatrão. O gás produzido pode ser considerado como possuidor de um poder calorífico relativamente alto dado o elevado número de hidrocarbonetos leves presentes em sua composição.

É apontado por Mitchell et al. apud Klass (1998) que um melhoramento pertinente ao processo gaseificação da biomassa com a utilização de vapor para obtenção do gás de síntese é que sejam utilizadas temperaturas mais elevadas assim como um catalisador para maximizar a gaseificação do carvão formado tal como dos produtos líquidos. Testes em escala laboratorial foram realizados com um catalisador a base de níquel, alumina e sílica, para gaseificação a vapor numa faixa de temperatura compreendida entre em $750{ }^{\circ} \mathrm{C}$ e $850{ }^{\circ} \mathrm{C}$. A função da sílica-alumina é a de craquear hidrocarbonetos de peso molecular intermediário e a função do níquel é a de promover a reforma do metano e a hidrogenação de hidrocarbonetos de maior peso molecular. Foi possível concluir que o gás de síntese pode ser obtido a partir de madeira pelo processo de gaseificação catalítica a vapor, com alto rendimento, em um reator de um único estágio a pressão atmosférica.

\subsubsection{Reações de gaseificação}

Andrade et al. (2007) apontam que a conversão térmica da biomassa se dá através de sua oxidação parcial em altas temperaturas que podem variar de $500^{\circ} \mathrm{C}$ a $1100{ }^{\circ} \mathrm{C}$ contudo, é importante mencionar que, nem todas as reações de gaseificação são conhecidas em sua totalidade. Na gaseificação da biomassa o assim chamado fator de ar é um parâmetro fundamental desse processo, sendo ele definido como a relação entre a razão ar/combustível (AC) - ou, de forma mais adequada, razão entre o agente oxidante/combustível - real e a estequiométrica, responsável por influenciar no rendimento do processo.

$$
\mathrm{AC}=\mathrm{V}_{\mathrm{ao} / \mathrm{c}} / \mathrm{ar}_{\mathrm{est}}
$$


Há uma relação de dependência entre o fator de ar (AC) e a temperatura do gaseificador uma vez que o aumento da vazão de alimentação do combustível (biomassa) em relação ao agente oxidante pode elevar as taxas de reação de oxidação do carbono, aumentando, conseqüentemente, a temperatura do sistema. Teoricamente a maior temperatura deveria ser resultado de uma taxa $\mathrm{AC}$ estequiométrica igual a $1(\mathrm{AC}=1)$ quando não ocorrer a formação de nenhum outro gás combustível no interior do gaseificador. Se a relação agente oxidante/combustível for baixa não haverá oxigênio suficiente para manter a reação de oxidação em seu estado ótimo, provocando uma queda na temperatura do sistema acarretando o fim da reação. Já, se a relação agente oxidante/combustível for muito alta, o excesso desse agente poderá causar uma queda na temperatura da reação ao consumir muita energia para seu aquecimento e assim, devido à absorção de calor pelo agente a ser consumido, poderá haver também o fim da reação de oxidação. Dessa forma tem-se que o fator de ar é fundamental para o desempenho do gaseificador mas cada relação ar/combustível ótima depende das especificações da biomassa utilizada.

Conforme apontado por Gómez apud Melo (2008) são encontrados na literatura valores de 0,2 a 0,4 para o AC. De acordo com Ushima (2004) nessa conversão térmica, a relação agente oxidante/combustível, na combustão da biomassa, ocorre abaixo da condição estequiométrica teórica (6:1 a 6,5:1), ocorrendo com a relação 1,5:1 a 1,8:1 (real); já Piffer (1999) indica que a quantidade ideal de ar para majorar a obtenção do monóxido de carbono e hidrogênio é a de $20 \%$ da quantidade estequiométrica, ou seja, uma relação de 1,2:1. Se obtido, tendo como agente oxidante o ar, o gás possuirá um poder calorífico entre 4 e $6 \mathrm{MJ}$ $\mathrm{Nm}^{-3}$, tido como baixo, sendo chamado de gás pobre. Se o agente oxidante for o oxigênio puro é possível a obtenção de um gás cujo poder calorífico está entre 10 e $20 \mathrm{MJ} \mathrm{Nm}^{-3}$ (SALLES; ANDRADE; LORA, 2005); isso porque, segundo Apolinario (2006), as perdas de energia associadas à presença de gases inertes, como é o caso do nitrogênio (constituinte de cerca de $80 \%$ em volume do ar atmosférico), são minimizadas. Ainda é possível aumentar o conteúdo de hidrogênio e monóxido de carbono pela adição de vapor de água ao ar de gaseificação (APOLINARIO, 2006). Esses gases, com diferentes valores de poder calorífico, podem ser empregados em diversas situações que vão desde sua queima para geração de calor em processos industriais, geração de eletricidade em turbinas ou utilização em rotas químicas para diferentes sínteses.

Conforme Jiang et al. apud Andrade et al. (2007) o agente oxidante, ou agente de gaseificação, pode ser o ar, ar com vapor de água ou ainda o oxigênio puro, já mencionados acima, sendo que para cada um desses gases haverá um poder calorífico diferente a ser obtido 
no gás gerado. A pressão é considerada um fator de relevância, uma vez que os reatores dos gaseificadores podem ser pressurizados ou atmosféricos; assim como a temperatura da operação no leito do gaseificador é um fator de grande importância, não somente para a qualidade do gás gerado mas também para o funcionamento ideal do reator uma vez que, dependendo da temperatura de funcionamento do mesmo, podem ocorrer fenômenos como a aglomeração e/ou sinterização do leito, o que poderia significar um colapso desse leito. A temperatura também irá influenciar na quantidade de alcatrões presentes no gás final - valores de temperatura da ordem de $800{ }^{\circ} \mathrm{C}$ são tidas como adequadas para redução da quantidade desses alcatrões (PAASEN; KIEL apud ANDRADE et al., 2007).

Hasler e Nussbaumer apud Sales; Andrade e Lora (2005) apontam que, além dos alcatrões, outros contaminantes estão presentes no gás produzido a partir da gaseificação. Substâncias como amônia $\left(\mathrm{NH}_{3}\right)$, o perigoso ácido cianídrico $(\mathrm{HCN})$ e alguns voláteis são encontrados dependendo da tecnologia e biomassa escolhidas, podendo causar danos consideráveis aos equipamentos e processos que utilizarão esse gás. $\mathrm{O}$ gás obtido precisa ser limpo antes de ser utilizado em algum motor a combustão interna, turbinas para geração de potência ou ser aplicado para fins químicos e ainda deverá atender também aos padrões de qualidade ambiental. A escolha de um sistema de limpeza adequado dependerá de alguns fatores como as características do gás, custos operacionais e de investimento, espaço físico disponível, nível de emissões desejado, dentre outros. De uma forma geral é possível indicar a composição elementar média do gás, de acordo com a tecnologia e o agente de gaseificação escolhidos conforme indicado na tabela (2.3).

\section{Tabela 2.3 Composição elementar média (\%) do gás de gaseificação}

\begin{tabular}{|c|c|c|c|c|c|c|c|c|c|}
\hline \multirow{2}{*}{$\begin{array}{l}\text { Tipo de } \\
\text { Gaseificador }\end{array}$} & \multirow{2}{*}{$\begin{array}{c}\text { Azgente } \\
\text { gaveificador }\end{array}$} & \multicolumn{5}{|c|}{ Composip̆ăo média do ges (\%) } & \multirow{2}{*}{$\begin{array}{c}\mathrm{PC} \\
(\mathrm{WIJ} \mathrm{W}+\mathrm{tri}-3)\end{array}$} & \multicolumn{2}{|c|}{ Qualidade do gás } \\
\hline & & $\mathrm{H}_{2}$ & $\mathrm{CO}$ & $\mathrm{CO}_{2}$ & $\mathrm{CH}_{4}$ & $\mathrm{H}_{2}$ & & Aleaträo & Partioulados \\
\hline Co-comente & at & 17 & 21 & 13 & 1 & 48 & 57 & boa & truediana \\
\hline Co-conente & $\mathrm{O}_{2}$ & 32 & 48 & 15 & 2 & 3 & 10,4 & boa & boa \\
\hline Contracorrente & $a+$ & 11 & 24 & 9 & 3 & 53 & 5,5 & baika & boa \\
\hline Leito fhuidicado & ar' & 9 & 14 & 20 & 7 & 50 & 5,4 & ttle diana & baika \\
\hline
\end{tabular}

Fonte: (Adaptado de SALES; ANDRADE; LORA, 2005).

De acordo com Melo (2008), no interior de um gaseificador ocorrem complexas reações que, em termos teóricos, podem ser dividas em diferentes zonas. Na primeira delas, denominada zona de secagem, há a remoção da umidade presente na biomassa alimentada. Essa, por sua vez, pode conter elevado grau de umidade dependendo de sua natureza e se 
sofreu ou não uma pré-secagem. Matérias como a lenha recém cortada ou o bagaço da canade-açúcar podem apresentar cerca de 50\% de umidade. Em seguida tem-se a zona de pirólise onde ocorre a formação de produtos sólidos, voláteis e alcatrões em decorrência da degradação térmica da biomassa alimentada na ausência ou com pouco oxigênio. Bridgwater apud Melo (2008) aponta que essa degradação térmica ocorre em temperaturas entre $500{ }^{\circ} \mathrm{C}$ e $1000{ }^{\circ} \mathrm{C}$ gerando um complexa mistura de compostos orgânicos que incluem outros combustíveis em frações sólidas, líquidas e gasosas.

No interior do gaseificador ocorre a combustão da biomassa em contato com o oxigênio e cujo principal aspecto é a formação de dióxido de carbono e vapor de água em uma reação exotérmica, liberando calor que pode variar de $700{ }^{\circ} \mathrm{C}$ a $2000{ }^{\circ} \mathrm{C}$. Seguindo, há a fase de redução onde ocorrem reações endotérmicas em uma faixa de temperatura compreendia entre $800{ }^{\circ} \mathrm{C}$ a $1100{ }^{\circ} \mathrm{C}$. As diferentes zonas podem variar de posição em decorrência dos diferentes tipos/modelos de gaseificadores utilizados. De acordo com Melo (2008), Higman e van der Burgt (2003) e um estudo realizado pelo Centro Nacional de Referência em Biomassa (CENBIO), em 2002, algumas das inúmeras reações que fazem parte do processo de gaseificação da biomassa podem ser descritas, sendo divididas nas seguintes etapas:

1. Na primeira etapa ocorre a decomposição térmica da biomassa (pirólise) em temperaturas próximas a $600^{\circ} \mathrm{C}$. De maneira esquemática pode-se representar essa etapa da seguinte forma:

Biomassa + Calor $\rightarrow$ Alcatrão + Coque + Gases + Condensáveis

Reação (2.20)

2. Na segunda etapa o oxigênio, presente no agente oxidante, oxida parte do carbono fixo do combustível. Essa etapa é responsável por suprir energia térmica ao processo de volatilização e gaseificação:

$$
\mathrm{C}+1 / 2 \mathrm{O}_{2} \rightarrow \mathrm{CO} \quad \Delta \mathrm{H}=-111,00 \mathrm{MJ} \mathrm{kmol}^{-1}
$$

Reação (2.21)

$\mathrm{CO}+1 / 2 \mathrm{O}_{2} \rightarrow \mathrm{CO}_{2} \quad \Delta \mathrm{H}=-283,00 \mathrm{MJ} \mathrm{kmol}^{-1}$

Reação (2.22)

$\mathrm{C}+\mathrm{O}_{2} \rightarrow \mathrm{CO}_{2}$

$\Delta \mathrm{H}=-394,00 \mathrm{MJ} \mathrm{kmol}^{-1}$

Reação (2.23) 
Higman e van der Burgt (2003) apontam que as reações acima demonstram o "investimento" de $28 \%$ do poder calorífico do carbono puro na conversão desse carbono sólido em gás $(\mathrm{CO})$, conservando até $72 \%$ do poder calorífico do elemento. Na prática o combustível gasoso também contém hidrogênio $\left(\mathrm{H}_{2}\right)$ e em processos modernos pode conservar de $75 \%$ a $88 \%$ do poder calorífico original. Se esse valor fosse inferior a $50 \%$ provavelmente os processos de gaseificação nunca teriam se tornado comercialmente atrativos.

3. Na terceira etapa ocorre a gaseificação propriamente dita onde estão inclusas as reações heterogêneas (diferentes fases) e as reações homogêneas (mesmas fases):

- Reações Heterogêneas:

$\mathrm{C}+2 \mathrm{H}_{2} \rightarrow \mathrm{CH}_{4}$ (Reação de formação de metano)

Reação (2.24)

$\mathrm{C}+\mathrm{CO}_{2} \leftrightarrow 2 \mathrm{CO}$

Reação (2.25)

Encontra-se acima a reação de Boudouard, que descreve a formação do carbono pela decomposição do monóxido de carbono ou seu reverso.

$\mathrm{C}+\mathrm{H}_{2} \mathrm{O} \leftrightarrow \mathrm{CO}+\mathrm{H}_{2} \quad \Delta \mathrm{H}=+131,00 \mathrm{MJ} \mathrm{kmol}^{-1}$

Reação (2.26)

Acima é apresentada a reação de gás-de-água (ou gás-azul) ou reação carbono-vapor. O gás é obtido ao se passar a água, em forma de vapor, sobre o carvão incandescente, produzindo tal mistura quando a água é reduzida pelo carbono - reação favorecida em altas temperaturas por se tratar de uma reação endotérmica. A reação que se segue consiste em converter parte, ou todo, o monóxido de carbono em hidrogênio pela reação de “deslocamento" do monóxido de carbono ou “deslocamento” da água (Reação 2.27)

- Reações Homogêneas:

$\mathrm{CO}+\mathrm{H}_{2} \mathrm{O} \leftrightarrow \mathrm{CO}_{2}+\mathrm{H}_{2} \quad \Delta \mathrm{H}=-41,00 \mathrm{MJ} \mathrm{kmol}^{-1}$

Reação (2.27) 
Acima, a reação water gas shift reaction (WGSR), também conhecida como reação de "deslocamento" da água, tem como propósito majorar o rendimento do hidrogênio e promover a conversão do monóxido de carbono em dióxido de carbono. Segundo Karayildirim; Sinağ e Kruse (2008) a presença de sais e outros componentes minerais pode melhorar a taxa dessa reação, beneficiando assim a formação de hidrogênio. A influência desses sais gera um efeito cinético (catalítico) que decresce com o aumento da temperatura.

$\mathrm{CH}_{4}+\mathrm{H}_{2} \mathrm{O} \leftrightarrow \mathrm{CO}+3 \mathrm{H}_{2}$

Reação (2.28)

Pode-se perceber que nas reações (2.26) e (2.28) a adição de água (em forma de vapor) contribui para o aumento da produção do monóxido de carbono e hidrogênio - produtos primados pela gaseificação quando se objetiva o gás de síntese.

4. Na quarta etapa ocorre a quebra (cracking) dos alcatrões:

Alcatrões + Calor $+\mathrm{H}_{2} \mathrm{O}_{\text {(gasoso) }} \leftrightarrow \mathrm{CO}+\mathrm{CO}_{2}+\mathrm{CH}_{4}$ Reação (2.29)

5. Na quinta etapa ocorre a oxidação parcial dos produtos da pirólise

$\left(\mathrm{CO}+\mathrm{H}_{2}+\mathrm{CH}_{4}\right)+\mathrm{O}_{2} \leftrightarrow \mathrm{CO}_{2}+\mathrm{H}_{2}$

Reação (2.30)

Muitos experimentos e modelos matemáticos têm conseguido prever a maior parte das reações que irão ocorrer no processo de gaseificação da biomassa, assim como controlar o processo. Contudo, na realidade, ainda não se conhece com exatidão o que acontece no interior do gaseificador. Uma composição típica aproximada para o gás produzido pela gaseificação da biomassa cujo agente oxidante é o ar, é mencionada em Piffer (1999) e apresentada na tabela (2.4). 
Tabela 2.4 Composição típica (\%) do gás produzido pela gaseificação

\begin{tabular}{|c|c|}
\hline Componente & $\begin{array}{l}\text { Quantidade } \\
\% \text { ent volutne) }\end{array}$ \\
\hline Monoxido de cartono & 21,00 \\
\hline Dioxido de cartono & 920 \\
\hline Hidrogenio - - & 14,50 \\
\hline Vapor de sua & 4,80 \\
\hline Metaro & 1,60 \\
\hline Witrogênio & 48,40 \\
\hline Ontros & 0,50 \\
\hline
\end{tabular}

Fonte: (Adaptado de REED; DAS apud PIFFER, 1999).

\subsubsection{O gás de síntese}

De acordo com Al-Shalchi (2006) a descoberta do gás de síntese é atribuída a Fontana, em 1780, que propôs primeiramente a passagem de vapor de água através do carvão. O gás obtido é composto por uma mistura volumétrica de 50\% de hidrogênio, $40 \%$ de monóxido de carbono e o restante, normalmente, dividido em partes quase iguais de dióxido de carbono e nitrogênio e cujo poder calorífico situa-se próximo dos $11 \mathrm{MJ} \mathrm{Nm}^{-3}$. No século XIX uma grande rede de distribuição de gás-azul - como fora batizado dada a coloração azul produzida por sua chama - foi construída na maior parte das cidades de pequeno e médio porte da Europa, particularmente nos países industrializados, juntamente com dispositivos para sua produção que, por sua vez, era realizada através da passagem do vapor de água através do coque ou carvão incandescente à temperaturas de $1000^{\circ} \mathrm{C}$ ou maiores.

$\mathrm{C}_{(\text {amorfo) }}+\mathrm{H}_{2} \mathrm{O}_{(\mathrm{g})} \leftrightarrow \mathrm{CO}_{(\mathrm{g})}+\mathrm{H}_{2}(\mathrm{~g}) \quad \Delta \mathrm{H}=+13,57 \mathrm{kcal} \quad$ Reação (2.31)

Um outra reação que também ocorre, aparentemente a uma temperatura muito inferior, é:

$\mathrm{C}_{(\text {amorfo })}+2 \mathrm{H}_{2} \mathrm{O}_{(\mathrm{g})} \leftrightarrow \mathrm{CO}_{(\mathrm{g})}+2 \mathrm{H}_{2}(\mathrm{~g}) \quad \Delta \mathrm{H}=+9,91 \mathrm{kcal}$

Reação (2.32)

Ambas as reações apresentadas são endotérmicas e tendem a resfriar rapidamente o leito de coque ou carvão. Depois de um certo período de tempo - após as reações de formação 
do gás iniciarem - ar é insuflado para que ocorra um processo de combustão normal e assim o calor liberado reaqueça o coque ou carvão incandescente, continuando a suprir a energia requerida pelas reações endotérmicas. As reações que ocorrem com o oxigênio são:

$\mathrm{C}_{(\mathrm{amorfo})}+\mathrm{O}_{2(\mathrm{~g})} \leftrightarrow \mathrm{CO}_{(\mathrm{g})} \quad \Delta \mathrm{H}=-43,83 \mathrm{kcal}$

$\mathrm{C}_{(\mathrm{amorfo})}+\mathrm{CO}_{2(\mathrm{~g})} \leftrightarrow 2 \mathrm{CO}_{(\mathrm{g})} \quad \Delta \mathrm{H}=+17,23 \mathrm{kcal}$

Reação (2.34)

O nome gás-azul foi, ao se referir à mistura de monóxido de carbono e hidrogênio, posteriormente, mudado para synthesis gas ou simplesmente syngas (gás de síntese). Esse nome foi dado devido ao fato dessa mistura de gases ser apropriada para a produção de produtos sintéticos sem a adição posterior de outros reagentes. O gás de síntese é composto majoritariamente por monóxido de carbono e hidrogênio, e é um gás inodoro, incolor e também tóxico. Queima sem chama se introduzido no ar a uma temperatura de $574{ }^{\circ} \mathrm{C}$. Esse gás pode ser utilizado como combustível para geração de energia elétrica ou utilizado como insumo químico básico para um vasto número de aplicações da petroquímica industrial; assim como fonte para produção de hidrogênio combustível e também produção de metanol e amônia.

Atualmente o gás de síntese apresenta uma grande gama de aplicações - algumas em escala industrial e outras ainda em fase de pesquisa. Muitas foram as tecnologias desenvolvidas para o aproveitamento de seu potencial como insumo petroquímico. Utilizando diferentes rotas químicas é possível sintetizar o metanol e através dele muitos produtos como o metil terc-butil éter (MTBE), o ácido acético, dimetil éter (DME), dentre outros; ainda a partir do gás de síntese é possível a obtenção da amônia, etanol e também gasolina e óleo diesel - em meio a outros hidrocarbonetos - através da síntese Fischer-Tropsch. A figura (2.2) apresenta de forma didática as principais rotas químicas possíveis partindo-se do gás de síntese como insumo. 


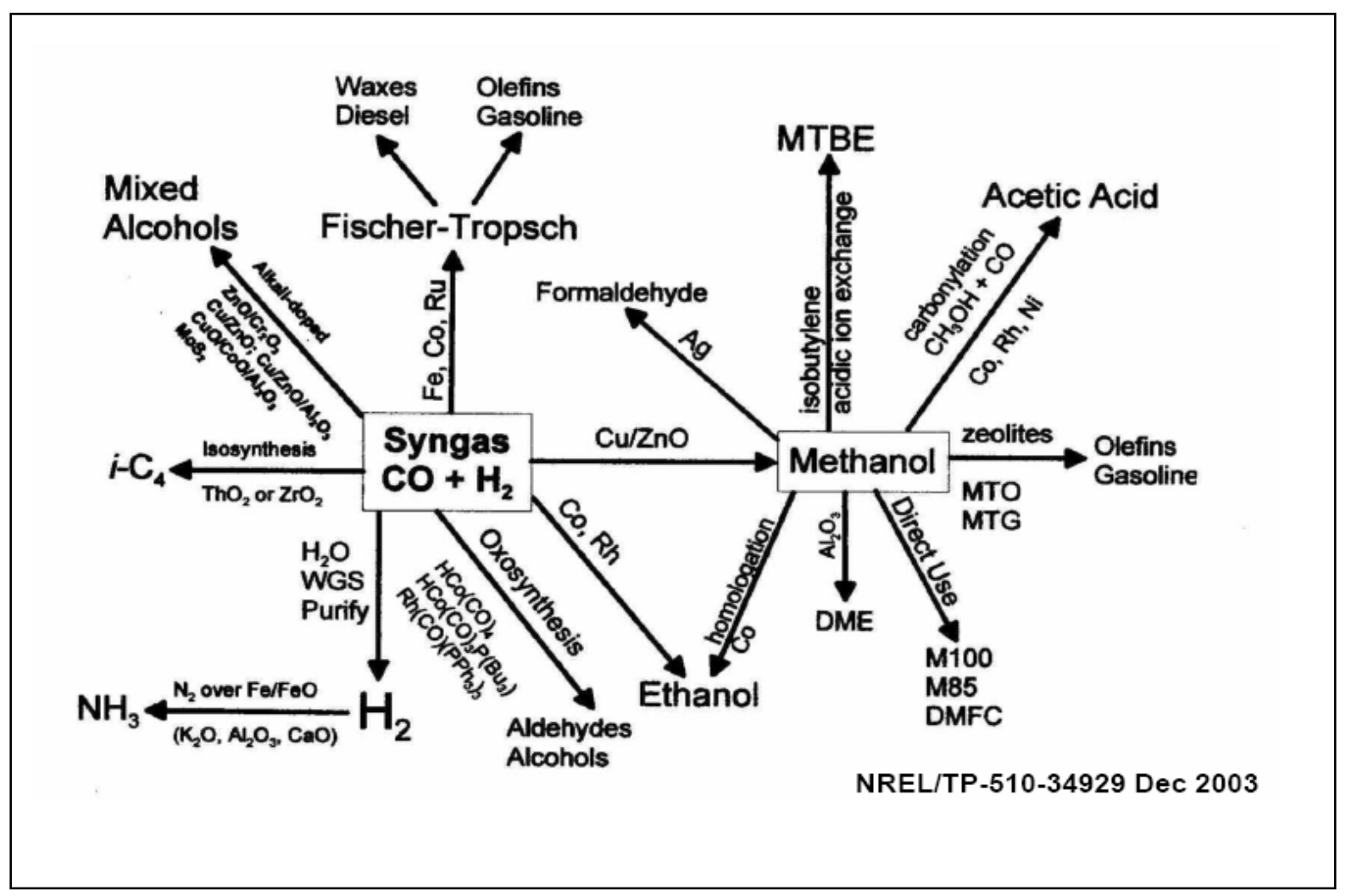

Figura 2.2 Produtos que podem ser obtidos partindo-se do gás de síntese (syngas) Fonte: (SPATH; DAYTON, 2003).

Gerosa (2007), Al-Shalchi (2006) e Probstein e Hick (1982) apontam que a síntese de hidrocarbonetos resultante da hidrogenação do monóxido de carbono foi descoberta em 1902 pelos químicos franceses Paul Sabatier (1854-1941) e Jean Baptiste Sanderens (1856-1937), ao obterem o metano e o metanol, variando-se a temperatura, após a passagem do hidrogênio e monóxido de carbono por catalisadores a base de ferro, cobalto ou níquel. Essa reação se mostrou reversível possibilitando a obtenção de uma mistura de monóxido de carbono e hidrogênio ao se passar metano por um leito catalítico de níquel.

$$
\begin{aligned}
& \mathrm{CO}+3 \mathrm{H}_{2} \rightarrow \mathrm{CH}_{4}+\mathrm{H}_{2} \mathrm{O}_{(\mathrm{g})} \\
& \mathrm{CO}+3 \mathrm{H}_{2} \rightarrow \mathrm{CH}_{3} \mathrm{OH}+\mathrm{H}_{2}
\end{aligned}
$$

Essas sínteses, idênticas na proporção de três moléculas de hidrogênio $\left(\mathrm{H}_{2}\right)$ para cada uma de monóxido de carbono (CO), são diferenciadas de acordo com as condições de processo de cada reator objetivando-se um produto ou o outro. Probstein e Hicks (1982) apontam que a pressão favorece o rendimento em ambos os casos mas ela, por si só, não é 
capaz de determinar o produto resultante. Ambas as reações são exotérmicas logo, o aumento da temperatura diminui o rendimento em ambos os casos. Entretanto o equilíbrio do metano não é deslocado para esquerda até que a temperatura se aproxime de $700 \mathrm{~K}$, fazendo assim com que o controle da temperatura seja um parâmetro capaz de selecionar o produto desejado. Assim, ao se operar a $700 \mathrm{~K}$, por exemplo, haveria uma mistura que conteria, virtualmente, nenhum metanol.

Segundo Gerosa (2007) no mesmo período histórico da reação de Sabatier-Sanderens foi realizada a primeira produção comercial de hidrogênio tendo-se como partida o gás de síntese. No ano de 1910 o químico polaco Fritz Habor (1868-1934) juntamente com o químico e industrial alemão Carl Bosch (1874-1940) desenvolveram o chamado processo Haber-Bosch da síntese do amoníaco a partir do hidrogênio e do nitrogênio a altas pressões, sendo que, o hidrogênio fora obtido a partir do gás de síntese. Segundo Spath apud Gerosa (2007) foi em 1913 que a primeira planta comercial de produção de amoníaco entrou em operação. Essa síntese representou um grande avanço para a contemporânea indústria química, uma vez que viabilizou a produção de produtos químicos nitrogenados como, por exemplo, explosivos e fertilizantes - principalmente o nitrato de sódio. Essa foi uma das aplicações mais bem sucedidas do gás de síntese, mesmo que de forma indireta. Poucos anos mais tarde o gás de síntese seria de suma importância para o processo conhecido como Fischer-Tropsch, representando um grande avanço científico na síntese dos combustíveis alternativos.

\subsubsection{Limpeza do gás de síntese}

Segundo Sales, Andrade e Lora (2005) após o processo de gaseificação o gás gerado necessita ser limpo antes de utilizado, seja para geração eletricidade, seja como insumo para processos químicos como a síntese Fischer-Tropsch ou a síntese do metanol. De acordo com Hamelinck et al. (2003) o gás produzido pela gaseificação da biomassa contém impurezas que são, tipicamente, compostos orgânicos como alcatrões e BTX (benzeno, tolueno e xileno) sendo o alcatrão definido por Nordgreen apud Melo (2008) como todo contaminante orgânico formado majoritariamente por hidrocarbonetos poliaromáticos condensáveis e com peso molecular superior ao do benzeno - impurezas inorgânicas como a amônia, o sulfeto de hidrogênio, o ácido cianídrico, ácido clorídrico, assim como metais voláteis e cinzas. Os 
contaminantes orgânicos podem ser removidos tanto por craqueamento (cracking) quanto por sistemas de lavagem (scrubbing). Assim que os compostos orgânicos são removidos as outras impurezas podem ser eliminadas por outros sistemas de limpeza de gases. No processo de gaseificação são formados hidrocarbonetos de longas cadeias, geralmente classificados como alcatrões e que, quando condensados, podem prejudicar o sistema como um todo dada sua deposição nas superfícies internas, assim como seu acúmulo em diferentes partes do reator. Piffer (1999) aponta que a biomassa, geralmente, pode produzir até $60 \%$ de alcatrões; preferencialmente esses alcatrões devem ser "quebrados" (cracked) em hidrocarbonetos menores dado seu potencial de produção de hidrogênio e monóxido de carbono; Paasen apud Melo (2008) constatou, experimentalmente, uma queda significativa no teor de alcatrões ao se operar em temperaturas próximas a $820^{\circ} \mathrm{C}$. Partindo-se do mesmo princípio, o metano e outros hidrocarbonetos leves podem sofrer reforma pela adição de vapor de água sobre uma superfície catalítica a base de níquel para maior produção de hidrogênio e monóxido de carbono. A escolha de qual sistema de limpeza de gases é mais adequado dependerá de uma série de diferentes fatores tais como a eficiência do sistema de lavagem, os custos de investimento e os custos operacionais, a temperatura e características do gás gerado, o tamanho das partículas de biomassa, dentre outros (HAMELINCK et al., 2003).

Melo (2008) indica que os contaminantes presentes no gás gerado causarão problemas nos equipamentos que venham a utilizá-lo caso o mesmo não seja adequadamente limpo. Os alcatrões, como já visto, caracterizam-se por ser uma complexa mistura de hidrocarbonetos condensáveis (principalmente de anéis benzênicos), é um dos maiores contaminantes encontrados no gás gerado. Guigon e Large apud Melo (2008) afirmam que o teor de alcatrões e material particulado contidos no gás pode variar de acordo com o tipo de gaseificador utilizado, conforme indicado na tabela (2.3). É explicado por Ushima (2002) que grande parte dos alcatrões são gerados na zona de pirólise em um gaseificador. A concentração destes alcatrões (em fase de vapor) no gás gerado pode atingir valores de até $120 \mathrm{~g} \mathrm{Nm}^{-3}$; é válido mencionar que esses alcatrões contêm uma considerável parcela da energia armazenada da biomassa. Piffer (1999) aponta que os sistemas de limpeza devem reduzir o teor dos alcatrões valores inferiores a $10 \mathrm{mg} \mathrm{Nm}^{-3}$.

É apontado por Devi et al. apud Melo (2008) e Hamelinck et al. (2003) que os métodos de remoção desses alcatrões são comumente classificados em dois tipos: os primários e os secundários. Os métodos primários consistem em tratamentos internos no gaseificador cujo maior propósito é tentar prevenir ou converter o alcatrão formado conforme demonstrado esquematicamente na figura (2.3). 


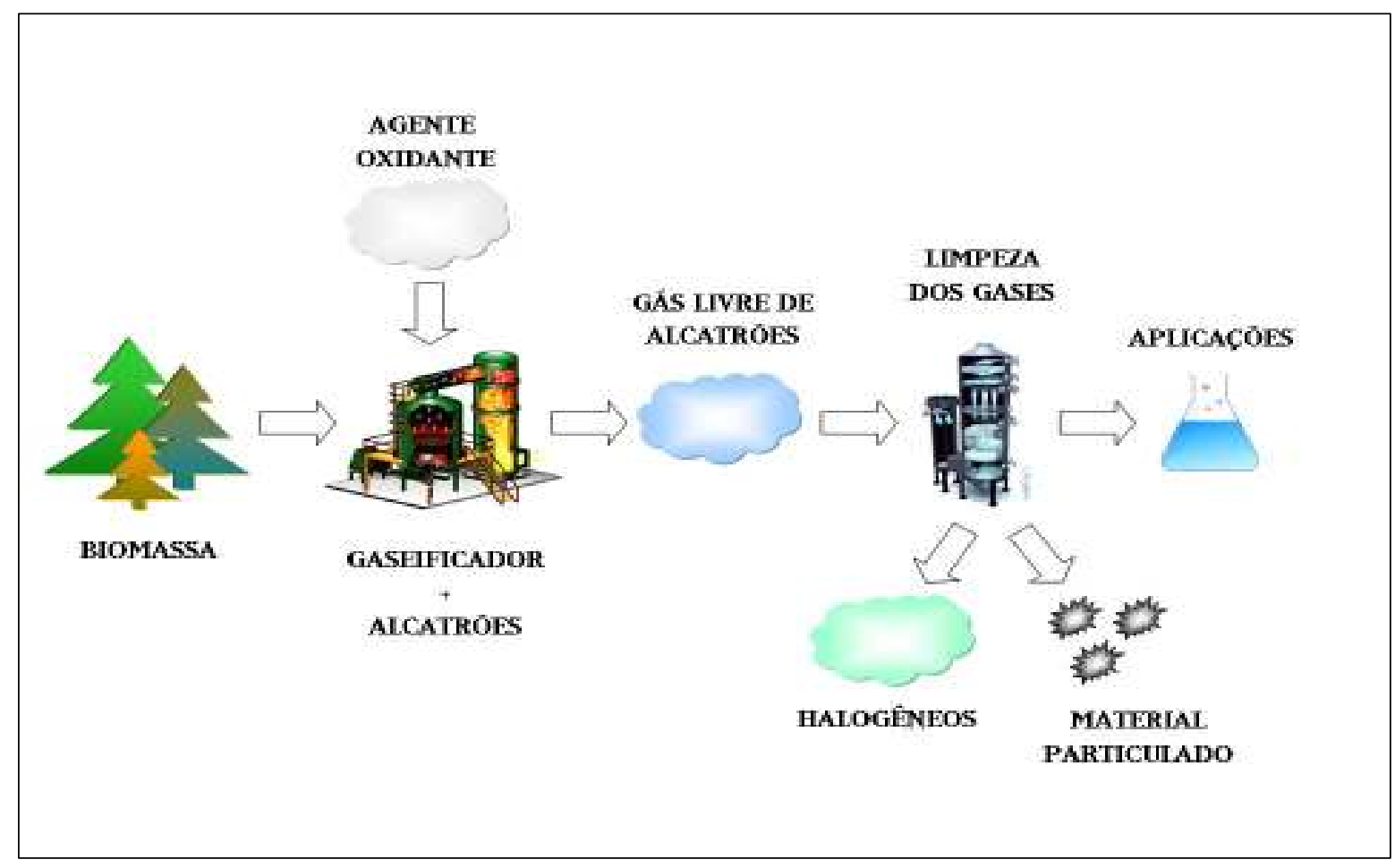

Figura 2.3 Métodos primários de remoção de alcatrões

Fonte: (Adaptado de DEVI et al. apud MELO, 2008).

Já os métodos secundários de tratamento consistem na remoção dos alcatrões após a saída do gás pelo gaseificador. Tais métodos podem ser químicos ou físicos, sendo divididos em métodos mecânicos (lavadores), craqueamento térmico e craqueamento catalítico. Milne et al. apud Hamelinck et al. (2003) indicam que sob temperaturas acima de $1000^{\circ} \mathrm{C}$ a $1200{ }^{\circ} \mathrm{C}$ os alcatrões são destruídos sem a necessidade de um catalisador, normalmente pela adição de vapor de água ou oxigênio.

(1) Craqueamento térmico: consiste em craquear (quebrar) os alcatrões formados, consumindo para isso parte do calor de processo, se fazendo necessária a injeção de pequenos volumes do agente oxidante para manter a combustão e assim alcançar a temperatura de craqueamento dos alcatrões, fornecendo-lhe dessa forma energia suficiente sem, é claro, comprometer a cinética do sistema;

(2) Craqueamento catalítico: trata-se de um método de remoção dos alcatrões por utilizar substâncias catalíticas como alguns compostos de níquel, silicato de ferro e o carbonato duplo de cálcio e magnésio - mais conhecido como dolomita; contudo, segundo Milne et al. apud 
Hamelinck et al. (2003), essa tecnologia ainda não está completamente testada e seus resultados ainda merecem mais estudo;

(3) Métodos mecânicos: caracterizam-se por sistemas compostos por lavadores e separadores de gás, filtros de mangas, filtros cerâmicos e ciclones. Todos esses são eficientes na remoção dos alcatrões, contudo quando a água é utilizada como fluido de limpeza, a mesma se torna um efluente de difícil tratamento e descarte. De acordo com Boerrigter et al. apud Hamelinck et al. (2003) é possível a remoção desses alcatrões fazendo-se uso de óleos a baixas temperaturas em um sistema avançado de lavagem. Posteriormente, os alcatrões são removidos do óleo e queimados no gaseificador. Já os compostos aromáticos (BTX) são apenas parcialmente removidos em gaseificadores atmosféricos, contudo sob pressões acima de 6 bar esses compostos são eliminados. A tabela (2.5) apresenta alguns sistemas mecânicos de limpeza de gás e suas respectivas capacidades de redução de alcatrões e materiais particulados, como, por exemplo, a torre de lavagem, o filtro de areia etc. A figura (2.4) demonstra, de forma esquemática, o momento em que se dá a remoção dos alcatrões por métodos secundários.

Tabela 2.5 Redução do teor de alcatrões e material particulado utilizando diferentes métodos mecânicos de limpeza.

\begin{tabular}{|c|c|c|c|}
\hline Sistema de Limpeza & $T(C)$ & $\begin{array}{c}\text { Reducto do teor de } \\
\text { particulados (\%) }\end{array}$ & $\begin{array}{c}\text { Reducta do teor de } \\
\text { alcatrăo (\%) }\end{array}$ \\
\hline Filtro de areia & $10 \mathrm{a} 20$ & 70 a 99 & 50 a97 \\
\hline Tome de lavagent & 50 a 60 & 60 a 98 & 10 a 25 \\
\hline Lavador Venturi & - & - & 50 a \\
\hline Precipitador eletrostítico & 40 a 60 & $>99$ & 0 a 60 \\
\hline Filtro de maries & 103 & 70 a 95 & 0 a 50 \\
\hline absorventes de aleaträo de leito fixo & 80 & - & 50 \\
\hline Craqueamento catalitico & 901 & - & $>95$ \\
\hline
\end{tabular}

Fonte: (Adaptado de HASLER; NUSSBAUMER apud SALES; ANDRADE e LORA, 2005). 


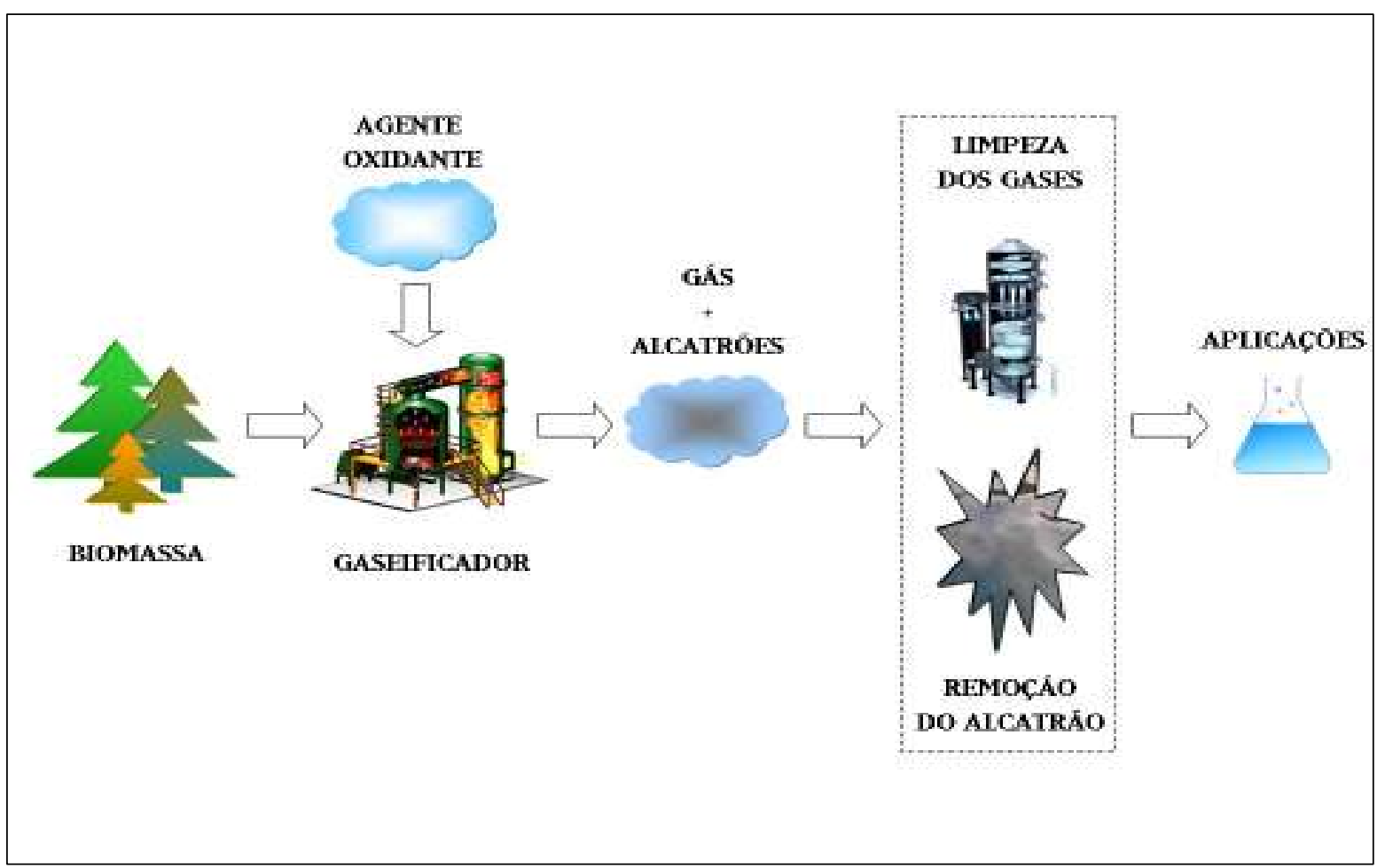

Figura 2.4 Métodos secundários de remoção de alcatrões

Fonte: (Adaptado de DEVI et al. apud MELO, 2008).

Após a remoção dos alcatrões é preciso eliminar as impurezas inorgânicas como as cinzas, fuligem e outros compostos particulados; haletos voláteis de metais alcalinos; compostos nitrogenados como a amônia e o ácido cianídrico; outras substâncias como o ácido clorídrico, ácido fluorídrico, ácido bromídrico e compostos sulfurados como o sulfeto de hidrogênio, todos através de tecnologias tradicionais ou avançados sistemas de limpeza a seco. Nos sistemas de limpeza a seco de gases os contaminantes são removidos por absorventes químicos a elevadas temperaturas. É apontado por Mitchell apud Hamelinck et al. (2003) que os sistemas a seco de limpeza de gases apresentam custos operacionais inferiores aos sistemas de lavagem úmidos. Há ainda a presença de água que, embora não seja um contaminante ou ofereça risco de envenenamento para os catalisadores que serão utilizados na síntese Fischer-Tropsch, ela atuará como um agente inerte, podendo diminuir a pressão parcial do gás de síntese. Sua remoção é feita logo em seguida, depois de condensada e resfriada após a limpeza do gás. Por fim, resta o dióxido de carbono cuja presença é considerável no gás de síntese e, embora não seja um reagente na síntese Fischer-Tropsch, sua presença influencia de forma negativa a formação de cadeias de hidrocarbonetos com mais de cinco átomos de carbono $\left(\mathrm{C}_{5+}\right)$. Tecnologias de absorção física ou membranas cerâmicas 
podem ser utilizadas para remoção do dióxido de carbono se, de acordo com Hendriks apud Hamelinck et al. (2003), este representar mais de 10\% do gás gerado, finalizando assim a limpeza do gás de síntese, tornando-o adequado para ser utilizado no reator Fischer-Tropsch. Em se tratando dos métodos mecânicos, Ushima (2002) aponta que muitos tipos de lavadores podem ser utilizados mas destaca o sistema de torres de lavagem em cascata, o lavador Venturi, lavadores centrífugos e torres com enchimento. É comum a utilização de sistemas distintos, porém combinados, para se atingir um estado ótimo de limpeza.

\subsubsection{Produção em escala piloto de gás de síntese no IPT}

O Instituto de Pesquisas Tecnológicas do Estado de São Paulo (IPT) foi fundado no ano de 1899 vinculado à Escola Politécnica da Universidade de São Paulo (USP). Situa-se na Cidade Universitária Armando de Salles Oliveira, na cidade de São Paulo, sendo uma das maiores instituições de pesquisa científica e desenvolvimento do país, possuindo décadas de atuação nas áreas de pesquisa, educação e tecnologia, além de outros dois centros tecnológicos nas cidades de Franca e Guarulhos, estado de São Paulo. Sua estrutura está distribuída em 25 divisões, possui 14 unidades técnicas e conta com mais de 70 laboratórios distribuídos em 62 prédios. Seu corpo é composto por cerca de 2.200 pessoas dentre mais de 500 pesquisadores, mais de 400 técnicos e ainda gestores e demais funcionários de apoio administrativo. O começo de sua história remete ao final do século 19 , começo de uma era voltada para ciência e de extraordinário desenvolvimento tecnológico. No ano de 1894 o engenheiro, político e professor Antonio Francisco de Paula (1843-1917), mais alguns engenheiros fundaram a Escola Politécnica de São Paulo, tornar-se-ia seu primeiro diretor, atuando de 1894 até a data de sua morte em 1917. Dada a crescente demanda da época por ensaios de materiais da engenharia civil um grupo de professores viria a criar, cinco anos mais tarde, o Gabinete de Resistência de Materiais, cujo núcleo básico se tornaria o Instituto de Pesquisas Tecnológicas, acompanhando o progresso da cidade com o passar dos anos. O IPT esteve presente em muitas das importantes fases da contemporânea história do país, atuando em épocas críticas, passando por duas guerras mundiais, desenvolvendo pesquisas para construção de estradas de ferro e usinas hidrelétricas; fabricação de granadas, morteiros, carros de combate e até mesmo o trem blindado; produtos industriais para construção de aviões; estudos para as fundições de gigantes como a usina de Volta Redonda e da Companhia 
Siderúrgica Nacional (CSN) e, no que tange a história do setor energético, a incumbência de adaptar os motores de combustão interna a gasolina para o gasogênio. Nas décadas seguintes o IPT esteve envolvido com grandes obras de engenharia do país, participando de forma intensa em seu processo de industrialização. Atualmente sua atuação é diversificada, passando pelas engenharias clássicas como a civil, mecânica e metalúrgica às áreas das ciências químicas e biotecnológicas, qualidade industrial, normalização, educação de nível superior, dentre muitas outras, desta forma se tornando uma referência nacional na orientação e solução de problemas tecnológicos (informação online) ${ }^{3}$.

É nesse contexto que, no período de tempo compreendido entre os anos de 1999 e 2000, o pesquisador do IPT, Ademar Hakuo Ushima, constantemente envolvido, nos últimos anos, em pesquisa e desenvolvimento de processos de gaseificação - resíduos oleosos e asfálticos - realizou um estudo envolvendo um processo de gaseificação de bagaço de canade-açúcar peletizado (Figura 2.5) em um gaseificador do tipo leito fluidizado borbulhante (Figura 2.6), trabalhando com pressão atmosférica, utilizando como agente oxidante o oxigênio puro $\left(\mathrm{O}_{2}\right)$ e adicionando vapor de água para geração de gás de síntese, ainda que em escala laboratorial (USHIMA, 2006).

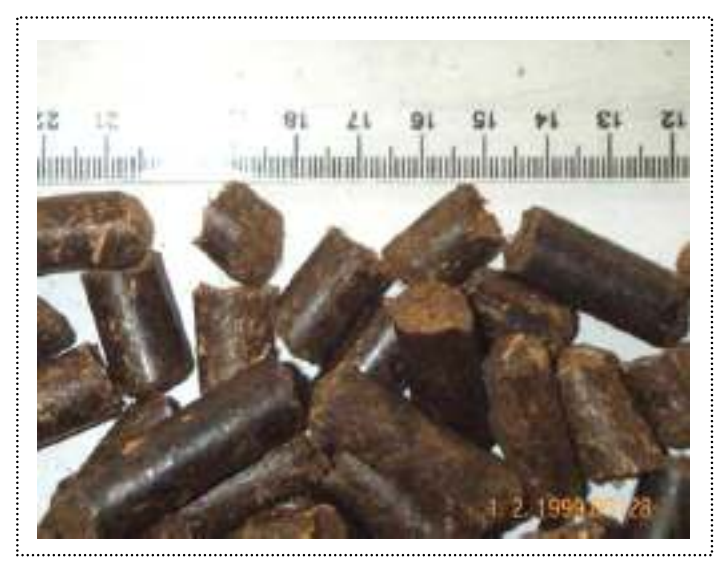

Figura 2.5 Bagaço de cana-de-açúcar condicionado em forma de pellets

Fonte: (USHIMA, 2006) 


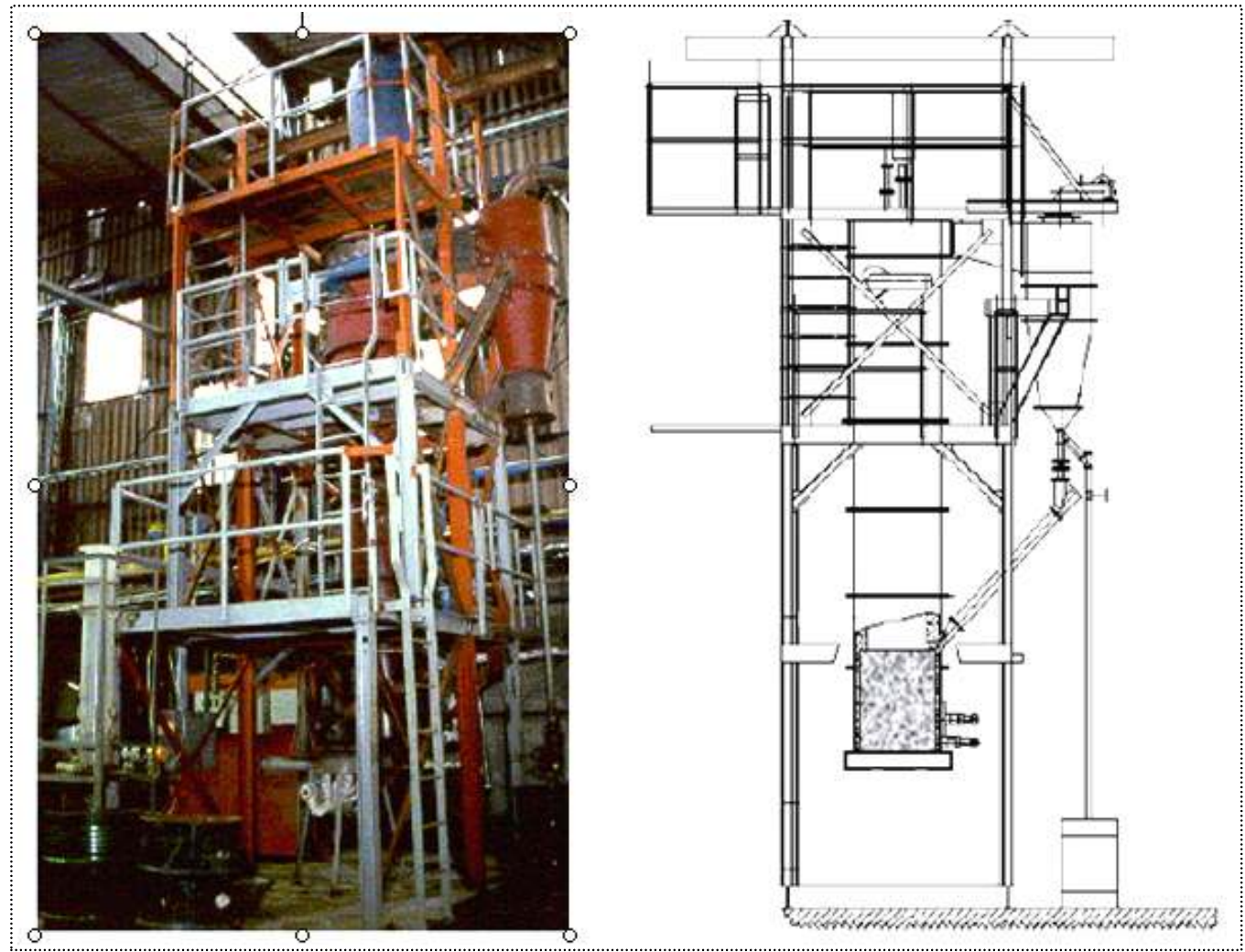

Figura 2.6 Gaseificador de leito fluidizado borbulhante: fotografia e esquemático

Fonte: (USHIMA, 2006)

A composição do gás de síntese obtido pode ser verificada na tabela (2.6) a seguir, de forma comparativa ao se usar como agente oxidante o ar e oxigênio puro com vapor de água, assim como a quantidade de umidade e o teor de alcatrões presentes.

Tabela 2.6 Composição (\%) do gás produzido pela de gaseificação de pellets de bagaço de cana-de-açúcar

\begin{tabular}{|c|c|c|c|}
\hline \multicolumn{4}{|c|}{ Gaseificador de leito fluidizado borbulhante } \\
\hline \multicolumn{2}{|c|}{ Azente de Gaseificação } & Ar & O2/Vapor \\
\hline \multicolumn{2}{|c|}{ Umidade da Biomassa (\% b.u.) } & 9,2 & 11,0 \\
\hline \multicolumn{2}{|c|}{$\mathrm{PCS}(\mathrm{MJ} / \mathrm{Nm} 3)$} & 5,9 & 13,6 \\
\hline \multicolumn{2}{|c|}{ Teor de Alcatrão ( $\mathrm{g} / \mathrm{Mm} 3)$} & - & 14,6 \\
\hline \multirow{7}{*}{ 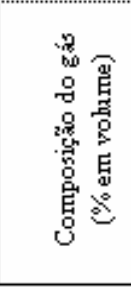 } & $\mathrm{CO}$ & 20,2 & 30,1 \\
\hline & $\mathrm{H} 2$ & 7,4 & 25,5 \\
\hline & $\mathrm{CH} 4$ & 6,0 & 10,7 \\
\hline & $\mathrm{CO} 2$ & 16,0 & 30,6 \\
\hline & $\mathrm{N} 2$ & 49,2 & 0,1 \\
\hline & 02 & 1,2 & 0,0 \\
\hline & Hidrocarbonetos & - & 3,0 \\
\hline
\end{tabular}

Fonte: (Adaptado de USHIMA, 2006). 
Posteriormente, em um segundo projeto, entre 2003 e 2006, viria a ser utilizado um outro tipo de gaseificador, um do tipo co-corrente (Figuras 2.7 e 2.8), com oxigênio e o bagaço de cana-de-açúcar também peletizado, em parceria com uma empresa privada especializada no aproveitamento industrial de subprodutos e excedentes da atividade sulcroalcooleira, a RAUDI Indústria e Comércio Ltda., em São Paulo, sob a administração de Ricardo Audi (C.E.O.). Tomando como argumento que a energia contida na cana-de-açúcar é, atualmente, subaproveitada (cerca de 75\%) a RAUDI Indústria e Comércio Ltda., em parceria com o IPT, desenvolveu um processo de gaseificação de biomassa para produção de gás de síntese (biosyngas) em condições adequadas para processos GTL e síntese Fischer-Tropsch batizado de "Projeto Raudi de Gaseificação". É objetivada a construção de um módulo de gaseificação pré-comercial que, futuramente, poderá ser replicado e alimentará uma unidade de síntese para diversos produtos (AUDI; FIASCHI, 2005). De forma esquemática pode-se visualizar o princípio do funcionamento do gaseificador co-corrente (Figura 2.7).

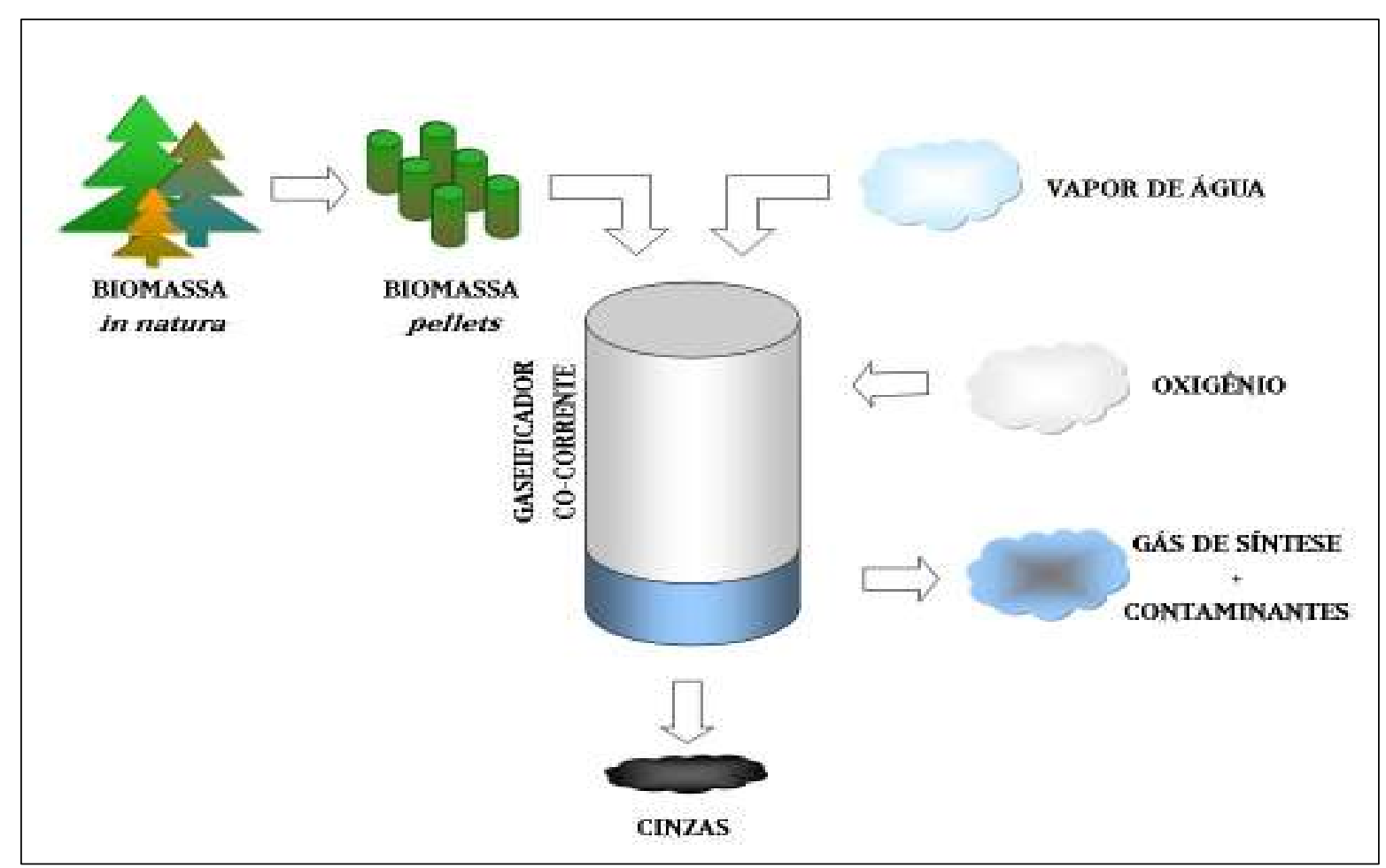

Figura 2.7 Gaseificador co-corrente (forma esquemática) de pellets de bagaço

Fonte: (Adaptado de USHIMA, 2006).

\footnotetext{
3 Material extraído do website do Instituto de Pesquisas Tecnológicas no Portal do Governo do Estado de São Paulo, disponível em $<$ http:// http://www.ipt.br> Acesso em 13.out.2008
} 
A seguir uma fotografia (Figura 2.8) do gaseificador desenvolvido pela parceria Raudi-IPT para a gaseificação de pellets de bagaço de cana e obtenção do gás de síntese.

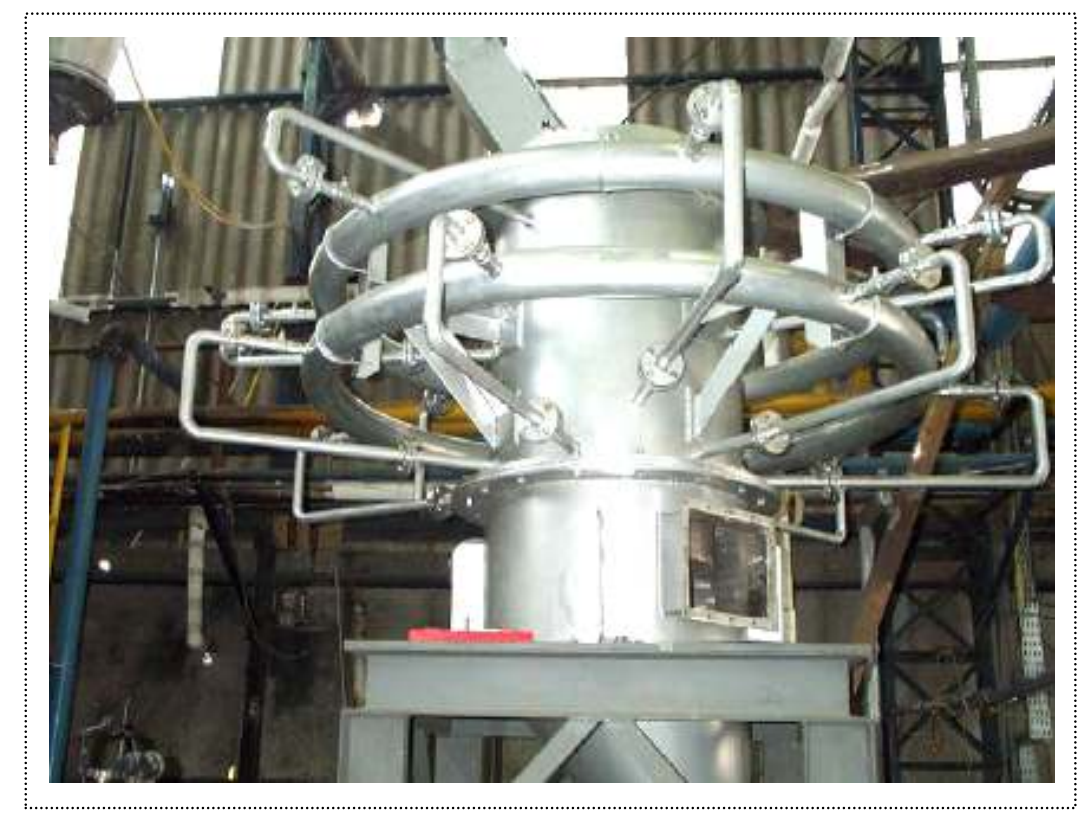

Figura 2.8 Gaseificador co-corrente desenvolvido pela parceira Raudi-IPT Fonte: (USHIMA, 2006)

A composição do gás de síntese obtido pelo processo de gaseificação com o equipamento desenvolvido pela parceria Raudi-IPT é apresentada na tabela (2.7).

Tabela 2.7 Composição (\%) do gás produzido no gaseificador Raudi-IPT

\begin{tabular}{|c|c|c|}
\hline \multicolumn{3}{|c|}{ Gaseificador Raudi-IPT } \\
\hline \multicolumn{2}{|c|}{ Agente de Gaseificap̧ão } & O2/Vapor \\
\hline \multicolumn{2}{|c|}{ Capacidade do gaseificador } & $110 \mathrm{~kg} / \mathrm{h}$ \\
\hline \multicolumn{2}{|c|}{ Teor de Alcatrão (g/Nm3) } & $3,5 \mathrm{~g} / \mathrm{Nm} 3$ \\
\hline \multirow{5}{*}{ 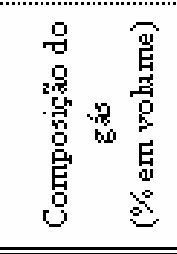 } & $\mathrm{CO}$ & 35,0 \\
\hline & $\mathrm{H} 2$ & 33,0 \\
\hline & $\mathrm{CH} 4$ & 5,0 \\
\hline & $\mathrm{CO} 2$ & 23,0 \\
\hline & Outros & 4,0 \\
\hline
\end{tabular}

Fonte: (Adaptado de USHIMA, 2006). 
Iniciativas como essa ainda são isoladas e de pouco destaque num panorama onde o próprio uso da biomassa é questionado por envolver muito mais do que aspectos tecnológicos. A utilização dos processos de gaseificação para as diversas variedades de biomassa ainda requer mais pesquisa e desenvolvimento, principalmente se o objetivo for a produção de um gás de síntese adequado para a síntese de produtos químicos, como por exemplo a dos líquidos Fischer-Tropsch ou outros, uma vez que o processo não reside apenas na escolha e tratamento da biomassa mais adequada para um fim específico, mas sim em inúmeras escolhas que devem ser feitas de acordo com as tecnologias disponíveis - e que continuam a ser aprimoradas - e com os sistemas que irão preparar esse gás para sua posterior utilização. Para esse propósito, a gaseificação da biomassa é apenas parte de uma cadeia produtiva maior, não apresentando, seu produto, um uso final em si mesmo, requerendo ainda mais atenção e comprometimento por parte de seus pesquisadores e idealizadores, fato este que pode ser comprovado dada a atenção que lhe tem sido dedicada nos últimos 10 anos. 


\section{SÍNTESE FISCHER-TROPSCH}

The need for energy and fuels is one of the common threads troughout history and is related to almost everything that man does or wishes to do.

(Donald L. Klass)

\subsection{O desenvolvimento histórico de uma tecnologia}

A tecnologia conhecida como Fischer-Tropsch pode ser considerada única em muitos sentidos dada sua proposição de "construir" cadeias de hidrocarbonetos mais longas a partir de moléculas menores, originadas de uma matéria-prima carbonada como o carvão, por exemplo, combinada com o hidrogênio, na forma do que se conhece como gás de síntese. Depois de "construídas", as cadeias de hidrocarbonetos podem ser convertidas em combustíveis veiculares líquidos para consumo final, como a gasolina e o óleo diesel, dentre outros insumos para indústria química e automotiva. Esse processo foi descoberto nos anos da década de 1920 e tem perdurado até a atualidade, ganhando notoriedade devido aos contratempos do mercado mundial de energia e fatores ambientais e sociais. O interesse nessa tecnologia e seu potencial relacionado aos combustíveis alternativos surgiu na década de 1930; em seguida, nos anos das décadas de 1940 e de 1950, continuou graças à necessidade por combustíveis veiculares na Alemanha nazista durante a II Guerra Mundial e à política de segregação racial conhecida como Apartheid, na África do Sul; nos anos de 1970 devido à crise mundial do petróleo; e já na atualidade - últimos 10 anos - é possível que tal interesse seja pela necessidade, cada vez maior, de fontes sustentáveis de produção de combustíveis líquidos menos danosos ambientalmente. No que diz respeito aos produtos Fischer-Tropsch suas propriedades ambientais têm sido reconhecidas como muito valiosas no que tange os combustíveis mais limpos e as percepções entre oferta e demanda, assim como o preço que o barril de petróleo tem atingido no mercado internacional nos últimos meses - apesar da crise financeira internacional - têm criado um incentivo econômico para a pesquisa de tecnologias alternativas consideradas menos poluentes. Esses fatores, quando combinados, conduzem às expectativas de que a tecnologia Fischer-Tropsch irá, ao menos, se tornar um fator 
significante de suporte ao abastecimento de combustíveis veiculares no cenário energético global. Inicialmente essa tecnologia era utilizada para converter carvão em combustível líquido sintético para transportes terrestres através da rota conhecida como Coal-to-Liquids (CTL), tendo sido amplamente utilizada na África do Sul após a construção da SuidAfrikaanse Steenkool en Olie ou South African Coal, Oil and Gas Corporation Limited Sasol, fundada em 1950 na cidade de Johanesburgo; posteriormente o gás natural - outro combustível de origem fóssil - tornar-se-ia a principal matéria-prima, em substituição ao carvão, ficando conhecido pela rota tecnológica Gas-to-Liquids (GTL). Nesse mesmo período os Estados Unidos da América também investiam nessa tecnologia a qual não obteve sucesso imediato, tendo sido utilizada somente durante a década de 1970, durante a crise do petróleo, sendo praticamente abandonada quando os preços do petróleo caíram.

Foi em 1925 que o professor alemão Franz Joseph Emil Fischer (1877-1947), diretor e fundador do Kaiser-Wilhelm Institute of Coal Research ${ }^{1}$, no distrito urbano de Mülheim um der Ruhr, Alemanha, e seu chefe de departamento, o tcheco Dr. Hans Tropsch (1889-1935), (Figura 3.1), ambos químicos de formação, descreveram um processo capaz de produzir hidrocarbonetos líquidos através do monóxido de carbono $(\mathrm{CO})$ e hidrogênio $\left(\mathrm{H}_{2}\right)$ na presença de catalisadores de metal, para serem utilizados como combustíveis e insumos para a indústria química. Os hidrocarbonetos sintetizados no processo são compostos, principalmente, de alcanos líquidos - também conhecidos como parafinas - e outros produtos, em menores quantidades, como os alcenos - também conhecidos como olefinas - álcoois, aldeídos e ácidos orgânicos. A síntese Fischer-Tropsch (FT), como ficou conhecida, conquistou seu lugar no setor industrial em 1935 com seu primeiro reator de leito fixo, numa planta-piloto, que operava em condições de pressão atmosférica, construído pela empresa Ruhrchemie AG uma companhia fundada pelos proprietários de indústrias da cidade de Ruhr após conseguirem os direitos sobre as patentes da síntese FT em 1934 - em Oberhausen-Holten, perto de Essen, Alemanha. Em meados de novembro de 1935, pouco após o regime nazista assumir o poder e iniciar sua busca pela independência do petróleo, quatro plantas FT de proporções comerciais encontravam-se em construção, todas propriedades da Ruhrchemie AG, que juntas somariam a capacidade de cerca de $724.10^{3}$ a $868.10^{3}$ barris de gasolina, óleo diesel, óleos lubrificantes e produtos petroquímicos.

\footnotetext{
1 Kaiser-Wilhelm-Gesellschaft zur Förderung der Wissenschaften (Kaiser Wilhelm Society for the Advancement of Science). Fundado em 1911 tinha como propósito o incentivo à pesquisa científica na Alemanha. Já teve ilustres diretores como Albert Einstein e Max Ernst Planck já foi seu presidente.
} 
Essas plantas operavam em condições de pressão atmosférica ou a pressões medianas que iam de 5 a 15 atmosferas, temperaturas que variavam de $180^{\circ} \mathrm{C}$ à $200{ }^{\circ} \mathrm{C}$, utilizavam gás de síntese proveniente do carvão e utilizavam um catalisador à base de cobalto, desenvolvido em 1933 pelo químico alemão Otto Roelen. Havia outras plantas menores em território alemão, uma na França, outra em Fushun, na Manchúria e duas no Japão. Até o início da década de 1940 cerca de 600.000 toneladas de hidrocarbonetos líquidos foram produzidos por ano em instalações industriais na Alemanha, todos feitos através da síntese FT; contudo, após a II Guerra Mundial, a produção de petróleo fez com que a produção dos líquidos FT não fosse mais rentável e as únicas instalações de produção ainda em operação encontravam-se na cidade industrial de Sasolburg, África do Sul e, posteriormente, em Secunda, nos arredores de Mpumalanga, também na África do Sul. Em 2004 essas duas fábricas eram operadas pela Sasol Synfuels Internacional (SSI), sendo responsáveis por cerca dos $28 \%$ do óleo diesel e da gasolina produzidos no país, processando 45 milhões de toneladas de carvão por ano (STEYNBERG; DRY, 2004).

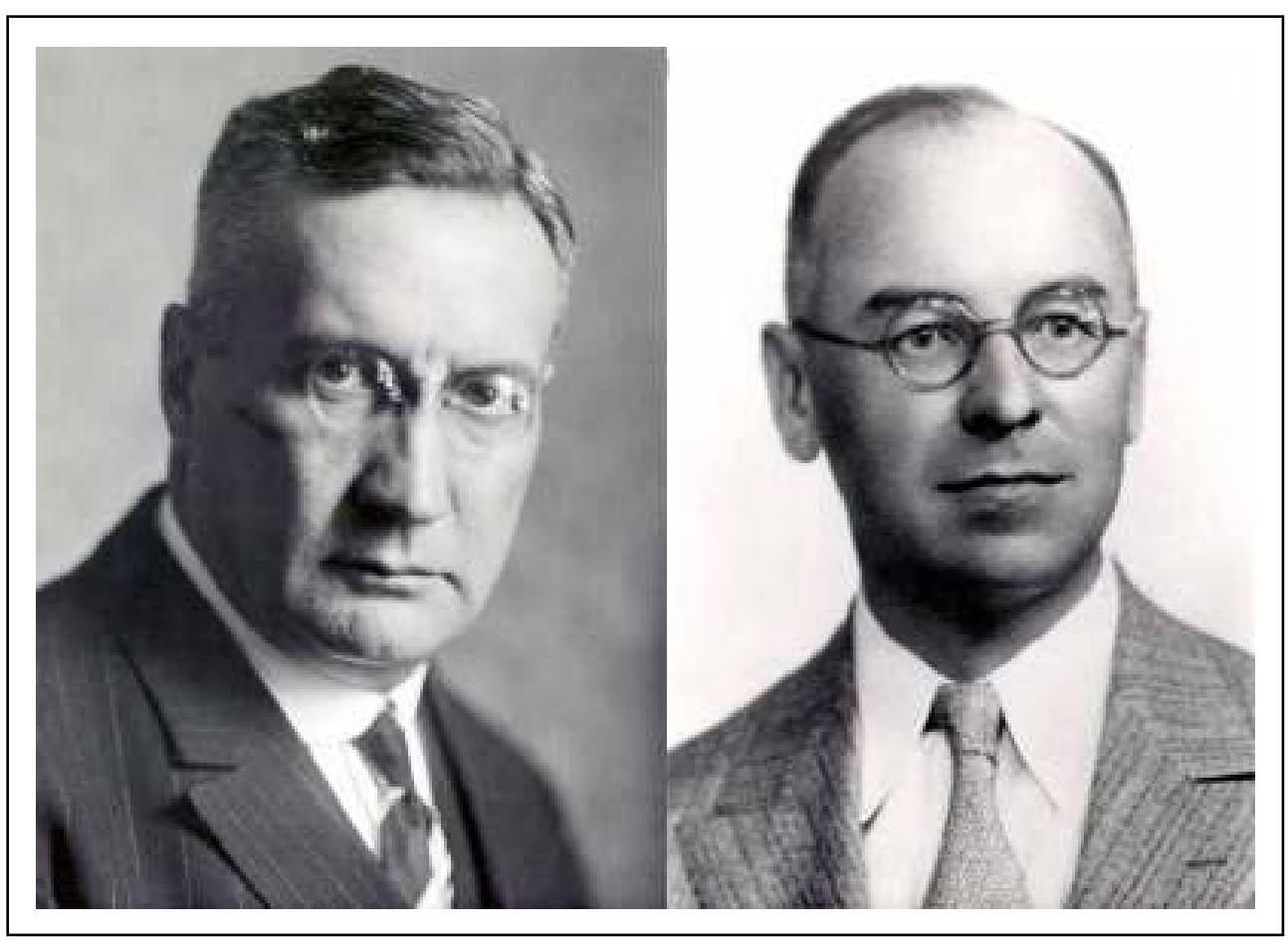

Figura 3.1 Professor Franz Fischer (esquerda) e Dr. Hans Tropsch (direita)

Fonte: (Max Planck Institute of Coal Research) (informação online) ${ }^{2}$.

\footnotetext{
2 Material extraído do artigo "The Return of a Classic to Fuel Production" disponível no website da Max Planck Society em 14 de dezembro de 2005. <http:// http://www.mpg.de/english/illustrationsDocumentation /documentation/pressReleases/2005/pressRelease20051214/index.html> Acesso em 09.jul.2008.
} 
Poucos anos mais tarde Franz Fischer e o pesquisador H. Pichler desenvolveram uma outra rota para síntese FT, utilizando pressões medianas e um catalisador à base de ferro que foi, posteriormente, comercializado pelas empresas Ruhrchemie AG e a também alemã Lurgi $\mathrm{GmbH}$ e aplicado à planta da Sasol, em Sasolburg, no ano de 1955. Posteriormente a tecnologia foi implantada pela Royal Dutch Shell em uma usina, em escala comercial, localizada em Bintulu, cidade costeira da Malásia, em 1993; e ainda na recente planta Oryx GTL Limited, no Qatar, Golfo Pérsico - resultado da parceria entre a Sasol e a Qatar Petroleum.

Tanto a conversão do carvão quanto do gás natural foram praticadas em inúmeros locais ao longo da história, por exemplo na cidade Brownsville, no Texas, EUA; há ainda a Petro S.A. (Mossgas), que se tornou a maior planta FT já construída, localizada em Mossel Bay, África do Sul e que opera pela da rota GTL. Outras tecnologias foram desenvolvidas e outras empresas petrolíferas de grande porte, como a norte-americana Phillips Petroleum Company, também se envolveram em pesquisa e desenvolvimento, na síntese dos combustíveis veiculares. Atualmente as únicas operações comerciais conhecidas se encontram na África do Sul, na Malásia e no Qatar. Quando em grandes plantas, as mesmas são beneficiadas pela economia de larga escala e normalmente consideradas viáveis de entrar em operação porém, para que esta tecnologia deixe de ser apenas praticada em pequena escala e passe a ser uma indústria moderna é preciso que seja adotada e praticada por muitas outras empresas. A tabela (3.1) apresenta as únicas plantas industriais que utilizam as tecnologias CTL e GTL atualmente.

Tabela 3.1 Unidades industriais Fischer-Tropsch em operação

\begin{tabular}{|c|c|c|c|c|c|}
\hline Companhias & Localização & Produtos & $\begin{array}{c}\text { Capacidade } \\
\text { (barris por dia) }\end{array}$ & Carga & Situação Atual \\
\hline Sasol & $\begin{array}{l}\text { Sasolburg e Secunda } \\
\text { (África do Sul) }\end{array}$ & $\begin{array}{l}\text { Combustíveis e } \\
\text { produtos especiais }\end{array}$ & 150.000 & Carvão & Em operação \\
\hline $\begin{array}{l}\text { Petro SA } \\
\text { (Mossgas) }\end{array}$ & $\begin{array}{l}\text { Mossel Bay } \\
\text { (África do Sul) }\end{array}$ & $\begin{array}{c}\text { Combustíveis e } \\
\text { produtos especiais }\end{array}$ & 22.500 & Gás Natural & Em operação \\
\hline Shell & Bintulu (Malásia) & $\begin{array}{l}\text { Combustíveis } \mathrm{e} \\
\text { produtos especiais }\end{array}$ & 12.500 & Gás Natural & Em operação \\
\hline $\begin{array}{c}\text { Sasole Qatar } \\
\text { Petroleum (Oryx) }\end{array}$ & Ras Laffan (Qatar) & Combustiveis & 34.000 & Gás Natural & Em operação \\
\hline
\end{tabular}

Fonte: (Adaptado de CALLARI, 2007). 
Para obter sucesso comercial as plantas que empregam o GTL precisam ser construídas em escalas competitivas. Em muitos casos, tecnologias como esta, que produzem na média de centenas de barris por dia, precisariam ter sua produção multiplicada por um fator de 100 vezes ou mais, sendo que os riscos são consideráveis e quaisquer erros ou omissões durante o planejamento e desenvolvimento poderão acarretar em atrasos, prejudicando assim o projeto (STEYNBERG; DRY, 2004).

A construção da planta Oryx GTL Limited, uma joint venture entre a Sasol e a Qatar Petroleum, com uma capacidade de 34.000 barris/dia, significou o primeiro passo concreto e há muitas razões para se crer que a tecnologia desenvolvida pelos pesquisadores Franz Fischer e Hans Tropsch está no caminho para se tornar uma nova indústria global. O sucesso da aplicação comercial da tecnologia FT requer uma vasta gama de competências. Algumas das maiores companhias petrolíferas podem ser capazes de colocar em uso instalações FT a partir de, principalmente, tecnologia já existente, já que é esperado que as possíveis plantas requeiram cooperação entre diversos fornecedores tecnológicos.

Um exemplo de cooperação ocorreu em 2000 com a joint venture entre a Sasol da África do Sul e a base da norte-americana Chevron Corporation, localizada na Califórnia, EUA. Foi então formada a Sasol Chevron, uma aliança global com o objetivo de por em prática a tecnologia FT para conversão de gás natural em produtos líquidos. O projeto da unidade FT é baseado na tecnologia desenvolvida pela Sasol, em Sasolburg, África do Sul. A Sasol também possui uma aliança com a IHI do Japão para o fornecimento dos reatores FT uma vez que os únicos fabricantes desses grandes reatores em uma escala comercial localizam-se no Japão e Coréia (STEYNBERG; DRY, 2004).

Em 2004 mais nove plantas de GTL estavam sendo planejadas para serem construídas em todo o mundo; por outro lado, durante os últimos anos muitas instituições na Alemanha têm investido em pesquisa com o intuito de desenvolver processos para criar combustíveis líquidos a partir da biomassa, numa rota conhecida, mais recentemente, como Biomass-toLiquids (BTL), que faz uso da tecnologia FT. Entre essas instituições estão a Forschungszentrum Karlsruhe; a Clausthal University of Technology, em ClausthalZellerfeld; a Future Energy GmbH e a Chören Industries GmbH na cidade de Friburgo, no sul da Alemanha. Na rota BTL o gás de síntese é produzido a partir de madeira, palha e de outras matérias-primas carbonadas de origem vegetal e apresenta, em termos tecnológicos e ambientais, diferenças consideráveis do gás anteriormente obtido a partir do carvão ou gás natural. 


\subsection{A síntese Fischer-Tropsch}

As duas principais características da síntese Fischer-Tropsch são (1) a possibilidade de produção de uma vasta gama de cadeias de hidrocarbonetos, sejam elas de parafinas (alcanos), olefinas (alcenos) ou produtos oxigenados, tais como alcoóis e ácidos carboxílicos; e (2) a liberação de grandes quantidades de calor dado que as reações são altamente exotérmicas. De acordo com Pichler et al. apud Dijk (2001), a maior parte dos produtos formados são parafinas lineares, $\alpha$-olefinas e alcoóis lineares também. Na síntese FT o gás de síntese é convertido em uma mistura de diversos tipos de hidrocarbonetos. Vessia (2006) indica que a síntese FT é, em princípio, um processo de construção de cadeias carbônicas onde grupos monoméricos de $\left(-\mathrm{CH}_{2}-\right)$ são "anexados" a uma cadeia carbônica contudo, quais são as reações que ocorrem e a forma com que ocorrem é matéria de controvérsias desde a década de 1930 e razão de muitos estudos e proposições desde então.

\subsubsection{Probabilidade de formação e crescimento de cadeias de hidrocarbonetos}

Conforme Hamelinck et al.. (2003) e Vessia (2006) a síntese FT produz cadeias de hidrocarbonetos de diferentes tamanhos e o crescimento dessas cadeias é modelado a partir da reação do monóxido de carbono $(\mathrm{CO})$ com o hidrogênio $\left(\mathrm{H}_{2}\right)$, indicada pela reação $(3.1)$, na superfície de um catalisador metálico, seja de ferro (Fe) ou cobalto (Co), comumente. As reações que ocorrem dentro do reator carecem de um detalhamento maior sobre seu comportamento mas de forma geral é possível descrevê-las pelas reações (3.2) até (3.6):

$$
\begin{array}{lll}
\mathrm{nCO}+(\mathrm{n}+\mathrm{m} / 2) \mathrm{H}_{2} \rightarrow \mathrm{C}_{\mathrm{n}} \mathrm{H}_{\mathrm{m}}+\mathrm{nH}_{2} \mathrm{O} & & \text { Reação (3.1) } \\
\mathrm{CO}+2 \mathrm{H}_{2} \rightarrow-\mathrm{CH}_{2}-+\mathrm{H}_{2} \mathrm{O} & \Delta \mathrm{H}=-165 \mathrm{~kJ} \mathrm{~mol}^{-1} & \text { Reação (3.2) } \\
2 \mathrm{CO}+\mathrm{H}_{2} \rightarrow-\mathrm{CH}_{2}-+\mathrm{CO}_{2} & \Delta \mathrm{H}=-204,7 \mathrm{~kJ} \mathrm{~mol}^{-1} & \text { Reação (3.3) } \\
\mathrm{CO}+\mathrm{H}_{2} \mathrm{O} \rightarrow \mathrm{H}_{2}+\mathrm{CO}_{2} & \Delta \mathrm{H}=-39,8 \mathrm{~kJ} \mathrm{~mol}^{-1} & \text { Reação (3.4) }
\end{array}
$$




$$
\begin{array}{lll}
3 \mathrm{CO}+\mathrm{H}_{2} \rightarrow-\mathrm{CH}_{2}-+2 \mathrm{CO}_{2} & \Delta \mathrm{H}=-244,5 \mathrm{~kJ} \mathrm{~mol}^{-1} & \text { Reação (3.5) } \\
\mathrm{CO}_{2}+3 \mathrm{H}_{2} \rightarrow-\mathrm{CH}_{2}-+2 \mathrm{H}_{2} \mathrm{O} & \Delta \mathrm{H}=-125,2 \mathrm{~kJ} \mathrm{~mol}^{-1} & \text { Reação (3.6) }
\end{array}
$$

As reações (3.1) a (3.6) são exotérmicas. Cerca de $20 \%$ da energia química são convertidos em calor, que precisa ser removido para que seja mantida uma vida ótima para o catalisador e para o controle da velocidade das reações dentro do reator. Na atualidade são encontradas duas opções distintas: a síntese FT a baixas temperaturas (LTFT - Low Temperature Fischer-Tropsch) cuja temperatura varia entre $180{ }^{\circ} \mathrm{C}$ e $240{ }^{\circ} \mathrm{C}$, utilizada na produção de parafinas (ceras leves - softwaxes; ou pesadas - hardwaxes), na presença de um catalisador de ferro ou cobalto que, após a etapa conhecida como hidroprocessamento, são convertidas em óleo diesel ou nafta; e a altas temperaturas (HTFT - High Temperature Fischer-Tropsch), cuja temperatura varia entre $300^{\circ} \mathrm{C}$ e $350{ }^{\circ} \mathrm{C}$, utilizada para produção de gasolina e $\alpha$-olefinas na presença de um catalisador de ferro. Outros catalisadores incluem aqueles baseados em níquel e rutênio; contudo, como a disponibilidade do rutênio é limitada, isso o torna muito custoso, excluindo-o de processos comercialmente viáveis. Os catalisadores à base de níquel possuem uma alta atividade porém produzem metano em demasia e em condições de altas pressões seu rendimento é baixo. Restam os catalisadores à base de ferro e cobalto, sendo o ferro um elemento barato; já os à base de cobalto apresentam maior atividade e longevidade mas são, comparativamente, 1000 vezes mais caros do que os catalisadores à base de ferro.

Vessia (2006) aponta que para grandes reatores comerciais da síntese FT o controle da temperatura é primordial, sendo esse o aspecto mais importante da estruturação do processo para se obter uma seletividade ideal no decorrer da vida do catalisador. Com o passar dos anos, foram desenvolvidos reatores comerciais como (1) o reator de leito fixo multitubular que consiste em milhares de finos tubos imersos em água - para o controle da temperatura com superfície catalítica interna por onde passa o gás de síntese; (2) o reator do tipo slurry, largamente utilizado, consistindo de elementos fluidos e sólidos, onde o catalisador não possui uma posição fixa, fluindo na forma de pequenas esferas juntamente com os demais componentes reagentes; e (3) e os reatores de leito fluidizado que são caracterizados pelo comportamento fluido dos catalisadores. Dry apud Vessia (2006) aponta que os reatores de leito fixo multitubular e do tipo slurry operam nas condições LTFT enquanto os de leito fluidizado nas condições HTFT. No interior desses reatores a variação do comprimento das cadeias carbônicas será determinado pela probabilidade das cadeias de hidrocarbonetos se 
propagarem $(\alpha)$ ou terminarem $(\beta)$. Na década de 1930, o químico norte-americano Paul John Flory (1910-1985) e o pesquisador Schulz formularam um modelo matemático que predizia uma distribuição de massa desses polímeros por meio da adição, passo a passo, de monômeros $\left(-\mathrm{CH}_{2}-\right)$. Em Steynberg e Dry (2004) é apontado que, após essa primeira aproximação, foi incorporada, por Friedel e Anderson, ao modelo proposto, uma expansão em que era possível verificar a formação de hidrocarbonetos ramificados. Segundo Jun (2004) foi em 1946 que o físico-químico britânico, doutor E.F.G. Herrington tratou de estudar essa probabilidade de crescimento de cadeias de hidrocarbonetos, sendo ele um importante pesquisador que dedicou parte de suas pesquisas para o estudo dos hidrocarbonetos combustíveis durante a II Guerra Mundial. Em 1951 sua formulação foi redescoberta por dois colegas do Bureau of Mines dos EUA, Robert B. Anderson e Sol Weller. O mecanismo de reação consistia em uma polimerização que levava a uma distribuição de produtos com diferentes pesos moleculares e que acabou por ser denominada distribuição Anderson-SchulzFlory (ASF). Esta distribuição determina uma relação entre o rendimento do produto e o número de carbonos, mostrando uma seletividade desde produtos gasosos (hidrocarboneto leves), passando pelos produtos líquidos (hidrocarbonetos de peso intermediário) até ceras (hidrocarbonetos sólidos). De forma esquemática pode-se observar, na figura (3.2), (1) a ligação do monóxido de carbono (CO) com a superfície catalítica; (2) a sua hidrogenação e (3) o surgimento do monômero $\left(-\mathrm{CH}_{2}-\right)$ e a água $\left(\mathrm{H}_{2} \mathrm{O}\right)$ como um dos produtos. Vessia (2006) indica que para um crescimento estequiométrico ideal das cadeias de hidrocarbonetos são necessárias duas moléculas de hidrogênio $\left(\mathrm{H}_{2}\right)$ para cada molécula de monóxido de carbono (CO). Essa relação é a taxa $\mathrm{H}_{2} / \mathrm{CO}$ e pode variar, comumente, entre 1,7:1 e 3:1 contudo, é correto afirmar que, uma vez que o conhecimento sobre o processo FT ainda é limitado, a modelagem da distribuição dos produtos (cadeias de hidrocarbonetos) também não é precisa.

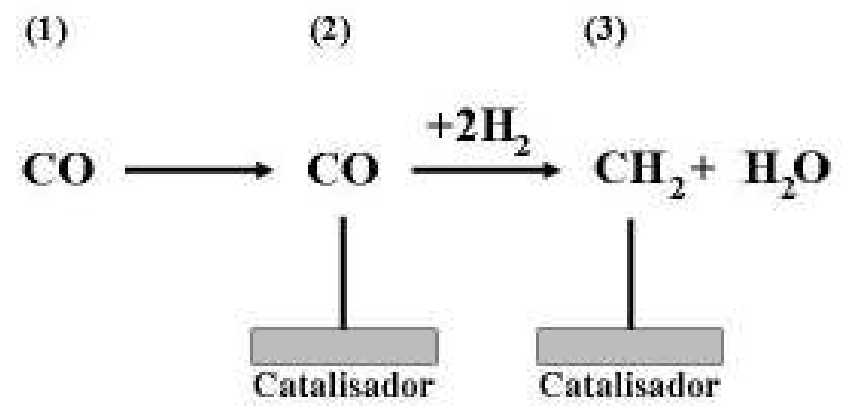

\section{Figura 3.2 Modelo de iniciação da cadeia de hidrocarbonetos}

Fonte: (Adaptado de VESSIA, 2006); 
O modelo proposto por Anderson, Schulz e Flory (ASF) é um modelo estatístico simples que relaciona de forma linear o logaritmo da massa molar do hidrocarboneto e o seu número de carbonos. A probabilidade do crescimento (ou seletividade) da cadeia é expressa pela constante $\alpha$ e o rendimento dos hidrocarbonetos com $n$ moléculas de carbono é dado pela equação (3.1) e demonstrado no gráfico (3.1).

$$
C_{n}=\alpha^{n-1}(1-\alpha)
$$

Onde:

$\alpha=$ probabilidade de crescimento da cadeia

$n=$ comprimento dos hidrocarbonetos

$\mathrm{C}_{\mathrm{n}}=$ fração de hidrocarbonetos que possuem comprimento $n$

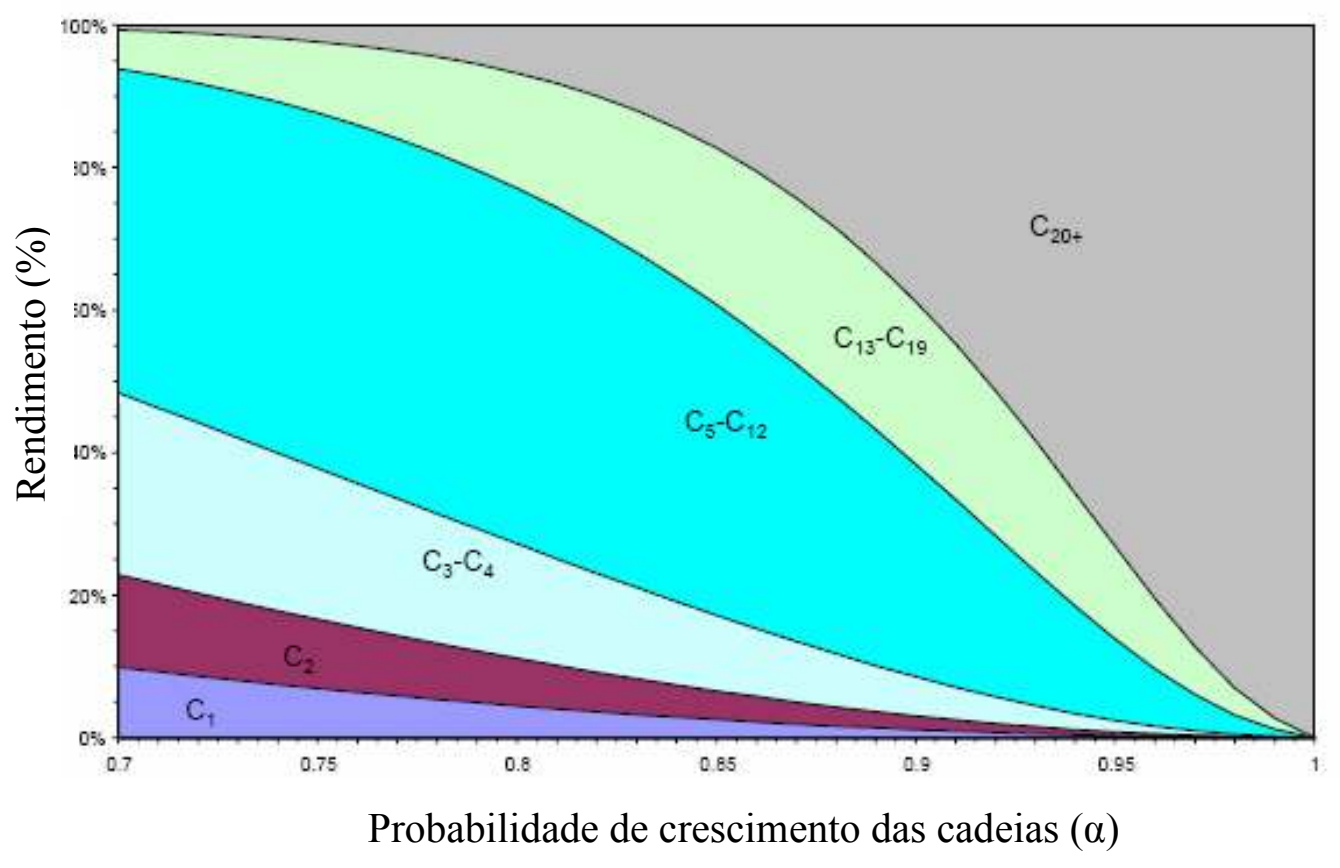

\section{Gráfico 3.1 Distribuição dos produtos FT para diferentes valores de $\alpha$}

Fonte: (HAMELICK et al., 2003)

Concernente ao gráfico (3.1) pode-se tomar como exemplo $\alpha=0,85$ (abscissa), onde há predominância dos hidrocarbonetos cujo peso molecular varia de $\mathrm{C}_{5}$ a $\mathrm{C}_{12}$, apresentando 
assim um rendimento (ordenadas) de aproximadamente $47 \%$ para essa faixa de produtos, sendo válido destacar que abaixo dela encontram-se os produtos gasosos $\left(\mathrm{C}_{1}-\mathrm{C}_{4}\right)$ e acima dela os demais hidrocarbonetos $\left(\mathrm{C}_{13}-\mathrm{C}_{20+}\right)$. Dessa forma, ao se objetivar um valor para a constante $\alpha$, escolhe-se qual faixa de hidrocarbonetos será desejada em detrimento de outras, sendo ela predominante porém não absoluta dada à presença, em menor quantidade, das demais faixas de produtos.

Uma outra forma de representar a distribuição ASF é apresentada no gráfico (3.2) onde é válido ressaltar que as cadeias carbônicas cujo comprimento vai de $C_{9}$ a $C_{11}$ são contadas duas vezes, em ambos produtos, gasolina e óleo diesel.

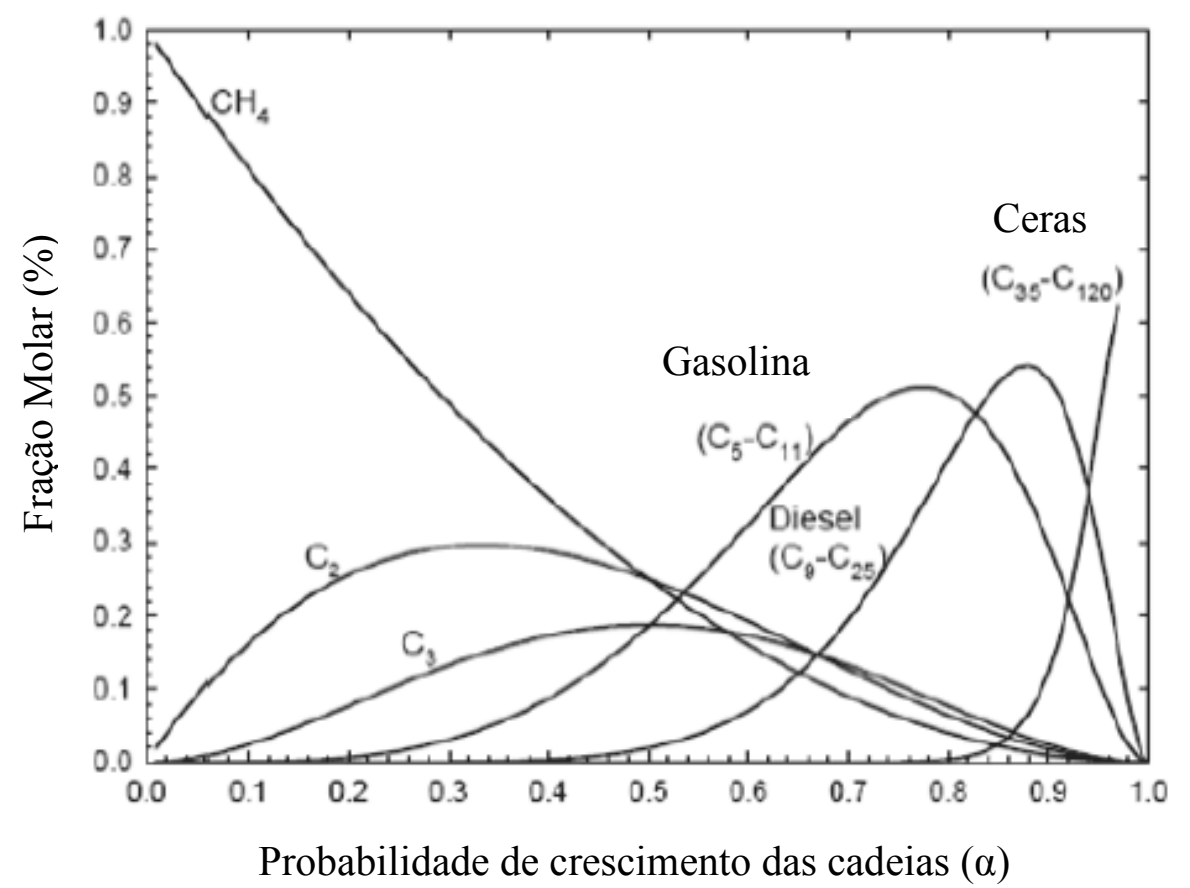

\section{Gráfico 3.2 Distribuição dos produtos FT para diferentes valores de $\alpha$}

Fonte: (Adaptado de VESSIA, 2006)

Dijk (2001) afirma que todo o espectro de produtos possíveis é descrito por um simples parâmetro, a constante de probabilidade de crescimento de cadeia $\alpha$, descrita pela relação entre a taxa de propagação das cadeias $\left(r_{p}\right)$ e a taxa de terminação das cadeias $\left(r_{t}\right)$, e onde $\phi_{i}$ representa a fração molar da faixa de produtos contendo $i$ átomos de carbono (weight fraction), podendo ser indicada pela equação (3.2). 
$\alpha=\sum_{i=n+1}^{\infty} \phi_{i} / \sum_{i=n}^{\infty} \phi_{i}=\frac{r_{p}}{r_{p}+r_{t}}$

Equação (3.2)

A distribuição dos produtos (seletividade) pode ser descrita também pela probabilidade de terminação das cadeias, expressa pela constante $\beta$, ao invés da constante $\alpha$, tendo sido definida pelo doutor Herrington em 1946 conforme demonstrado na equação (3.3):

$\beta=\phi_{i} / \sum_{i=n+1}^{\infty} \phi_{i}=\frac{r_{t}}{r_{p}}=\frac{1-\alpha}{\alpha}$

Equação (3.3)

Uma cadeia de hidrocarbonetos com $n$ átomos de carbono terá uma probabilidade definida por $\alpha^{\mathrm{n}-1}$ pois dependerá da probabilidade de formação de cada hidrocarboneto com cadeia menor do $n$, uma vez que é um processo de crescimento gradual. Tome-se, por exemplo, o pentano $\left(\mathrm{C}_{5} \mathrm{H}_{10}\right)$ que possui 5 átomos de carbono $(n=5)$. Sua probabilidade de formação é descrita, passo a passo, pelas equações de (3.4) à (3.8), e está diretamente relacionada com a probabilidade de formação do metano $\left(\mathrm{CH}_{4}\right)$, etano $\left(\mathrm{C}_{2} \mathrm{H}_{6}\right)$, propano $\left(\mathrm{C}_{3} \mathrm{H}_{8}\right)$ e butano $\left(\mathrm{C}_{4} \mathrm{H}_{10}\right)$, respectivamente, hidrocarbonetos com 1, 2, 3 e 4 átomos de carbono (HAMELINCK et al., 2003; VESSIA, 2006)

$\alpha_{\mathrm{C} 5+}=1-\left(\alpha_{\mathrm{C} 1}\right)-\left(\alpha_{\mathrm{C} 2}\right)-\left(\alpha_{\mathrm{C} 3}\right)-\left(\alpha_{\mathrm{C} 4}\right)$

Equação (3.4)

$\alpha_{\mathrm{C} 5+}=1-\left[\alpha^{1-1}(1-\alpha)\right]-\left[\alpha^{2-1}(1-\alpha)\right]-\left[\alpha^{3-1}(1-\alpha)\right]-\left[\alpha^{4-1}(1-\alpha)\right] \quad$ Equação (3.5)

$\alpha_{\mathrm{C} 5+}=1-\left[\alpha^{0}(1-\alpha)\right]-\left[\alpha^{1}(1-\alpha)\right]-\left[\alpha^{2}(1-\alpha)\right]-\left[\alpha^{3}(1-\alpha)\right] \quad$ Equação (3.6)

$\alpha_{\mathrm{C} 5+}=1-1+\alpha-\alpha+\alpha^{2}-\alpha^{2}+\alpha^{3}-\alpha^{3}+\alpha^{4}$

Equação (3.7)

$\alpha_{\mathrm{C} 5+}=\alpha^{4}$

Equação (3.8)

Segundo a interpretação de Flory, feita em 1936, tem-se, de forma geral, que a probabilidade de crescimento de uma cadeia de hidrocarbonetos com $n$ átomos de carbonos é dada pela equação (3.9) e pode-se escrever essa equação de probabilidade de um hidrocarboneto existir como sendo: 
$\alpha_{\mathrm{Cn}}=\alpha^{\mathrm{n}-1}(1-\alpha)^{2}$

Equação (3.9)

A potência 2 do termo 1- $\alpha$ aparece devido ao fato de que cada hidrocarboneto possui duas terminações potenciais que ainda não reagiram em cada extremo da cadeia. Entre essas extremidades existem $n$-1 ligações e a probabilidade de terminação dessa cadeia de hidrocarbonetos tem a probabilidade de 1- $\alpha$ para ser finalizada; a existência de duas justifica a potência quadrática no termo em questão.

Vessia (2006) e Dijk (2001) explicam que na maioria das vezes uma faixa específica de hidrocarbonetos é desejada acima das outras e isso é possível de se obter, em parte, através de ajustes nas condições das reações, mesmo que a faixa total de hidrocarbonetos seja extensa e cheia de incertezas dada à falta de detalhes sobre o processo e a cinética das reações. $\mathrm{O}$ rendimento de cada produto irá depender da probabilidade de crescimento das cadeias de hidrocarboneto que, por sua vez, depende da pressão, temperatura, composição do gás de síntese utilizado, composição do catalisador utilizado e também a tecnologia do reator FT aplicada. Na tabela (3.1) pode-se observar a influência que a temperatura, pressão, taxa Olefina/Parafina (O/P) e o tempo de permanência dos produtos dentro do reator FT exercem na constante de probabilidade $\alpha$, na conversão de olefinas para parafinas (taxa $O / P$ ), na conversão do gás de síntese e na linearidade dos hidrocarbonetos formados; sendo (+) a indicação que aquele parâmetro cresce; (-) que ele decresce e (N/A) que não exerce influência.

Tabela 3.2 - Influência das variáveis de processo na distribuição dos produtos.

\begin{tabular}{|c|c|c|c|c|}
\hline Warlatel do processo & $\alpha$ & Tara OrF & $\begin{array}{l}\text { Comversăo do } \\
\text { gat de sintse }\end{array}$ & Linearidade \\
\hline Tethoperatura & - & + & + & - \\
\hline Pressão & + & + & + & + \\
\hline $\mathrm{H} 2 \mathrm{CO}$ & - & - & + & $\mathrm{W} / \mathrm{A}$ \\
\hline T emtupo de pertraatıêtucia & + & - & $\mathrm{W} / \mathrm{A}$ & - \\
\hline
\end{tabular}

Fonte: (Adaptado de DIJK, 2001)

Em condições de baixa pressão há um aumento na seletividade de hidrocarbonetos ramificados com apenas o radical metil $\left(-\mathrm{CH}_{3}\right)$ e também um aumento das olefinas internas (olefinas nas quais não há ocorrência de dupla ligação no carbono $\alpha$ ); a formação de 
hidrocarbonetos aromáticos é observada somente em altas temperaturas e sobre uma superfície catalítica à base de ferro $(\mathrm{Fe})$, não ocorrendo com catalisadores de cobalto ou rutênio. Por exemplo, quando longas cadeias de hidrocarbonetos são desejadas utiliza-se para tal o processo LTFT, operando com temperaturas que podem variar de $180{ }^{\circ} \mathrm{C}$ a $240{ }^{\circ} \mathrm{C}$, pois temperaturas baixas favorecem a formação de cadeias mais compridas, conforme demonstrado no gráfico (3.3) fazendo-se uso de uma taxa $\mathrm{H}_{2}: \mathrm{CO}$ fixa igual a $2(\mathrm{r}=2)$; porém temperaturas muito baixas não são desejadas uma vez que reduzem a atividade do processo. Um grande desafio da síntese FT, ao se objetivar longas cadeias de hidrocarbonetos, é manter a temperatura baixa dada a natureza altamente exotérmica de suas reações.

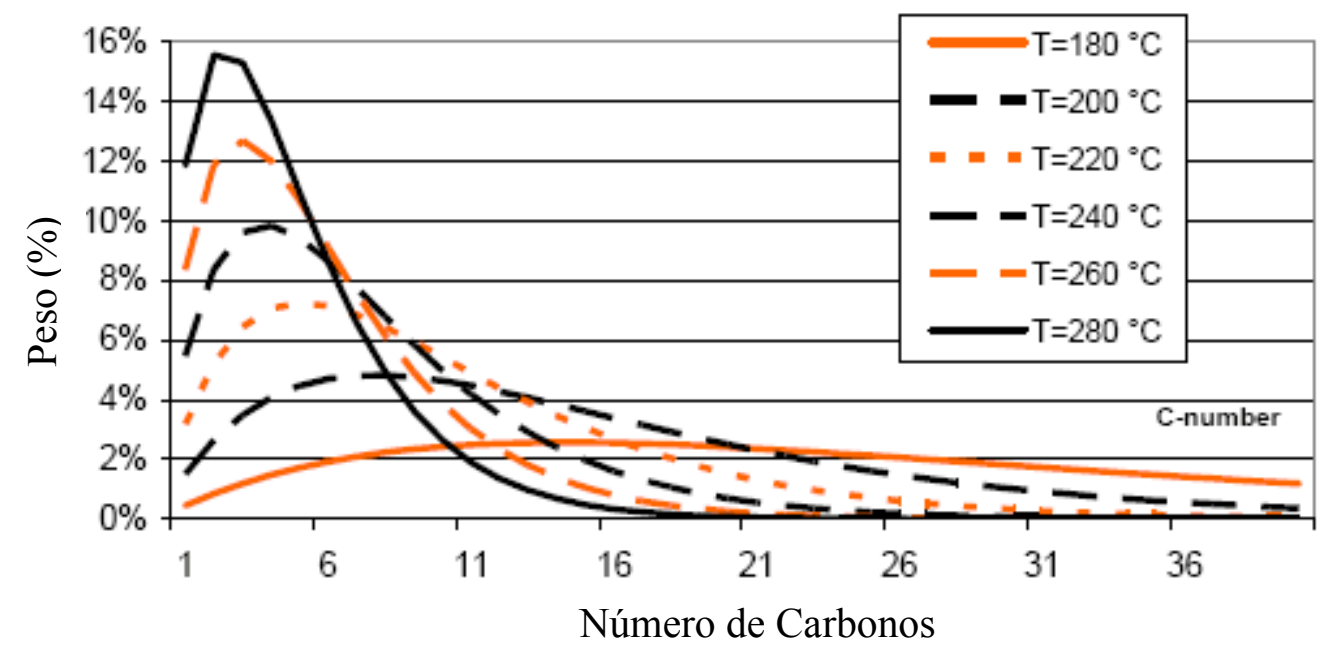

\section{Gráfico 3.3 Variação da temperatura com taxa $\mathrm{H}_{2}: \mathrm{CO}$ fixa $(\mathrm{r}=2)$}

Fonte: (Adaptado de SONG et al. apud VESSIA, 2006;)

Se, por ventura, cadeias menores forem objetivadas, é possível "quebrar" essas cadeias em hidrocarbonetos menores através do processo conhecido como hidrocraqueamento (hydrocracking) conforme apontado Hamelinck et al. (2003). Esse processo é semelhante ao craqueamento (craking) utilizado pela indústria petrolífera; contudo, o hidrogênio $\left(\mathrm{H}_{2}\right)$ tem participação fundamental nesse processo, sendo o responsável pela "quebra" das longas cadeias em cadeias menores, conforme mostram as reações (3.7) a (3.9). O hidrocraqueamento pode ocorrer espontaneamente dentro do reator FT ou ser aplicado, posteriormente, em parte dos produtos gerados (geralmente nos hidrocarbonetos sólidos).

$\mathrm{C}_{20} \mathrm{H}_{42}+\mathrm{H}_{2} \rightarrow 2 \mathrm{C}_{10} \mathrm{H}_{22}$

Reação (3.7)

$\mathrm{C}_{25} \mathrm{H}_{52}+\mathrm{H}_{2} \rightarrow \mathrm{C}_{10} \mathrm{H}_{22}+\mathrm{C}_{15} \mathrm{H}_{32}$ 
Quando o hidrocraqueamento ocorrer no interior do reator FT, o número de átomos de hidrogênios necessários para o processo de "quebra" das grandes cadeias em cadeias menores é chamado de deficiência de hidrogênio. No caso de cadeias carbônicas cujos comprimentos variem de $\mathrm{C}_{20}$ a $\mathrm{C}_{29}$, sua deficiência de hidrogênio é igual de 1 (reações 3.7 e 3.8); cadeias carbônicas cujos comprimentos variem de $\mathrm{C}_{30}$ a $\mathrm{C}_{39}$ possuem deficiência de hidrogênio igual a 2 (reação 3.9) e assim por diante.

A síntese FT produz alcanos e alcenos de diferente tamanhos pelo processo que é, basicamente, uma construção de cadeias carbônicas onde essas cadeias podem ganhar comprimento pela adsorção de um outro grupo de monóxido de carbono (CO) e hidrogênio $\left(\mathrm{H}_{2}\right)$ na forma do mero $\left(-\mathrm{CH}_{2}-\right)$, ou essas cadeias podem terminar, deixando a superfície catalítica para formar assim uma parafina ou uma olefina. Na figura (3.3), também de forma esquemática, é possível descrever esse mecanismo de crescimento uma vez que a cadeia já tenha se iniciado e verificar a formação de parafinas (sentido direto das reações) ou olefinas (sentido inverso das reações).

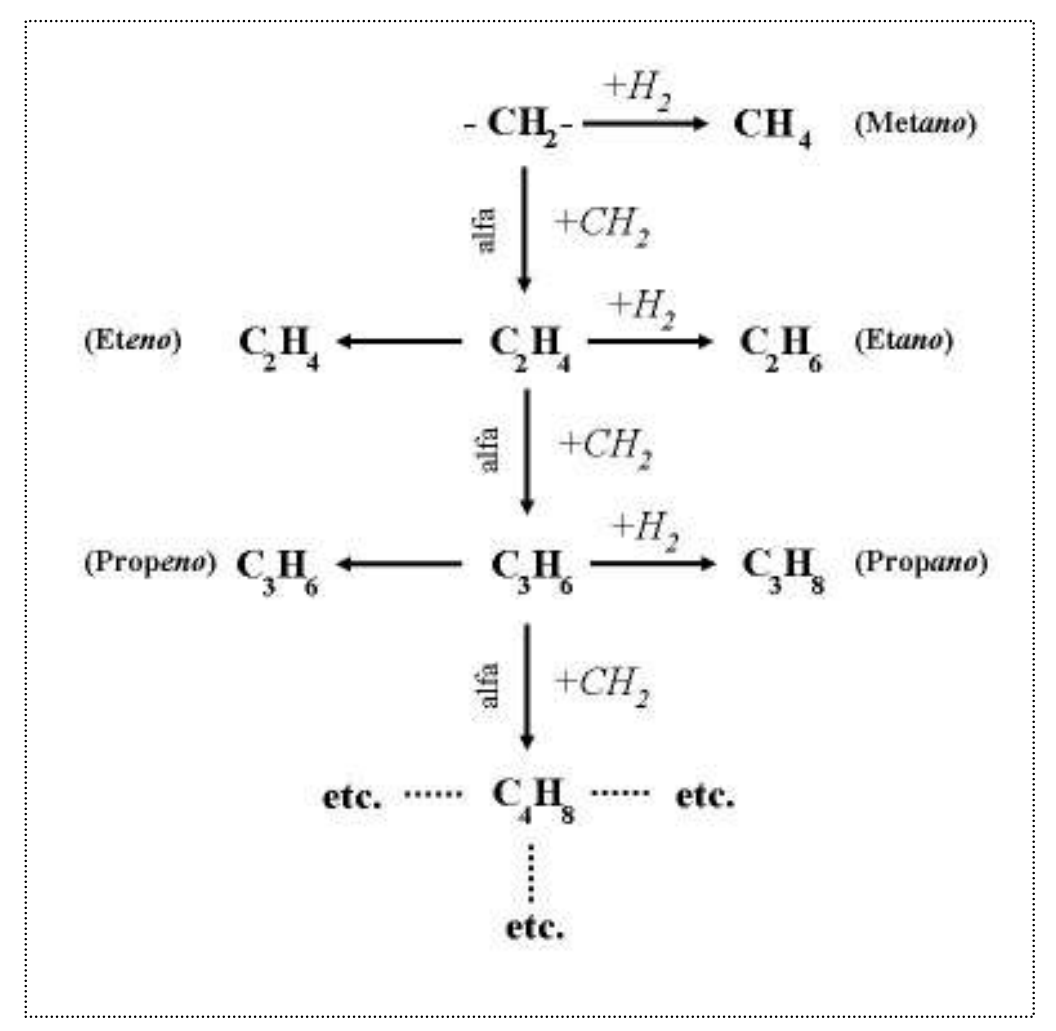

Figura 3.3 Modelo esquemático de crescimento e terminação de cadeias de hidrocarbonetos.

Fonte: (Adaptado de VESSIA, 2006) 
Segundo Jun (2004) as reações que ocorrem durante a síntese podem ser simplificadas em três distintas mais a reação de "deslocamento" da água:

(1) Formação de parafinas (alcanos):

$\mathrm{nCO}+(2 \mathrm{n}+1) \mathrm{H}_{2} \rightarrow \mathrm{C}_{\mathrm{n}} \mathrm{H}_{2 \mathrm{n}+2}+\mathrm{nH}_{2} \mathrm{O}$

Reação (3.10)

(2) Formação de olefinas (alcenos):

$\mathrm{nCO}+2 \mathrm{nH}_{2} \rightarrow \mathrm{C}_{\mathrm{n}} \mathrm{H}_{2 \mathrm{n}}+\mathrm{nH}_{2} \mathrm{O}$

Reação (3.11)

(3) Formação de produtos oxigenados:

$\mathrm{nCO}+2 \mathrm{nH}_{2} \rightarrow \mathrm{C}_{\mathrm{n}} \mathrm{H}_{2 \mathrm{n}+2} \mathrm{O}+(\mathrm{n}-1) \mathrm{H}_{2} \mathrm{O}$

Reação (3.12)

A água - que é um produto de formação primária - pode reagir com o monóxido de carbono $(\mathrm{CO})$ para formar o dióxido de carbono $\left(\mathrm{CO}_{2}\right)$ através da reação de "deslocamento" da água ou water gas shift reaction (WSGR) conforme descrito na reação (3.13):

$\mathrm{CO}+\mathrm{H}_{2} \mathrm{O} \leftrightarrow \mathrm{CO}_{2}+\mathrm{H}_{2}$

Reação (3.13)

Essa reação ocorre em um sistema de três fases: gasosa $\left(\mathrm{CO}, \mathrm{H}_{2}\right.$, vapor de água e hidrocarbonetos em estado gasoso), produtos líquidos e o catalisador (fase sólida). Segundo Geerling et al. apud Dijk (2001) os hidrocarbonetos fundidos formam uma camada de cera sobre a superfície catalítica, que se comporta como um líquido homogêneo borbulhante e que permanece em equilíbrio com a fase gasosa dentro do reator. A distribuição ASF é válida somente quando há a presença da constante probabilística de crescimento das cadeias de hidrocarbonetos, uma vez que a reação primordial consiste em uma adição um-a-um de um monômero à cadeia em crescimento; entretanto, na prática, a distribuição dos produtos difere significativamente da teoria da distribuição ASF, isso conforme Geerling et al.; van der Laan e Beenackers apud Hamelinck et al.. (2003), principalmente devido à hidrogenação e a reinserção das olefinas (alcenos) na região do crescimento das cadeias. Picher et al. apud Jun (2004) foram os primeiros que detectaram os desvios nos resultados experimentais da distribuição ASF que, por sua vez, podiam significar uma relativa alta na seletividade do 
metano $\left(\mathrm{CH}_{4}\right)$, conforme reação (3.14), uma relativa baixa na seletividade do etano $\left(\mathrm{C}_{2} \mathrm{H}_{6}\right)$ e uma maior do que esperada seletividade dos hidrocarbonetos de alto peso molecular, se comparados com o considerado ideal pela distribuição estudada por Anderson. Dijk (2001) afirma que os produtos primários formados podem, em certo ponto do processo, influenciar a distribuição dos demais hidrocarbonetos, também causando desvios na distribuição teórica ideal proposta por Anderson, Schulz e Flory.

$\mathrm{C}_{\mathrm{n}}+\mathrm{H}_{2} \rightarrow 2 \mathrm{C}_{\mathrm{n}-1}+\mathrm{CH}_{4}$

Reação (3.14)

De acordo com Tijmensen et al. apud Hamelinck et al. (2003) a reação (3.14) provoca um aumento do número de hidrocarbonetos com um carbono $\left(\mathrm{C}_{1}\right)$, assim como outros desvios que ocorrem com os outros compostos e seus respectivos números de carbonos. Muitas tentativas fracassaram em melhorar a seletividade da distribuição ASF. Jun (2004) aponta que alguns autores podem ter tentado interpretar os desvios da tradicional distribuição ASF se fazendo valer de uma superposição entre duas distribuições ASF. Eles suspeitam da existência de dois locais distintos para o crescimento das cadeias na superfície do catalisador e assim propuseram que cada um desses locais pode possuir um rendimento ideal para a distribuição ASF com diferentes probabilidades de crescimento das cadeias de hidrocarbonetos.

Steynberg e Dry (2004) declaram que importantes contribuições têm sido feitas com o intuito de compreender as particulares acerca das reações secundárias que ocorrem na síntese FT, como a dessorção das olefinas, parafinas, aldeídos e álcoois. Exposta sua complexidade o regime cinético FT é tido como uma "polimerização de superfície não-trivial" sendo suas reações de polimerização - combinação das cadeias de hidrocarbonetos com monômeros mais rápidas do que as reações de dessorção das espécies de superfície. Alguns modelos matemáticos procuram explicar a cinética dessas reações e também considerar a re-adsorção das olefinas, a hidrogenação das olefinas secundárias e também a isomerização dessas olefinas. Alguns desses desvios na distribuição teórica ASF podem ser tomados como "positivos" como é o fato de que a probabilidade de crescimento de hidrocarbonetos aumenta conforme o número de carbonos também aumenta, gerando assim, cadeias de hidrocarbonetos mais longas; isso ocorre graças à re-incorporação de $\alpha$-olefinas às cadeias ainda em crescimento (ainda em ligação organometálica). Para otimizar a produção de hidrocarbonetos líquidos na síntese FT é necessária uma mudança na distribuição de ASF. Uma forma de se fazer essa modificação é levar em consideração que as reações de re-inserção das olefinas têm um papel muito importante na distribuição dos produtos FT, tornando-se plausível uma 
explicação para os desvios. Puskas e Hulburt apud Steynberg e Dry (2004) explicam que a distribuição ASF somente seria possível, sem alterações, se as condições cinéticas no interior do reator fossem constantes em cada ponto da superfície catalítica da síntese o que, em verdade, não é possível de ser obtido. Desta forma, as reações da síntese FT podem ser divididas em cinco etapas distintas: (1) adsorção dos regentes; (2) formação das cadeias de hidrocarbonetos; (3) crescimento das cadeias de hidrocarbonetos; (4) término das cadeias de hidrocarbonetos; e (5) re-adsorção e reações secundárias das olefinas. Vessia (2006) aponta que para a otimização da produção de hidrocarbonetos específicos é necessário um maior entendimento da relação existente entre as condições de reação e a probabilidade de crescimento das cadeias carbônicas, o que requer expressões matemáticas que viabilizem modelos apropriados para descreverem a distribuição dos produtos. Foram desenvolvidos mais de 11 modelos diferentes para a constante de probabilidade $\alpha$ contudo, Lox apud Vessia (2006) foi quem formulou um modelo, denominado ALII, fazendo uso de um catalisador à base ferro, que se tornou referência na literatura, onde as pressões parciais do monóxido de carbono $(\mathrm{CO})$ e do hidrogênio $(\mathrm{H} 2)$ são os principais parâmetros do processo. Nesse modelo a temperatura utilizada é de $573 \mathrm{~K}\left(300^{\circ} \mathrm{C}\right)$ e a pressão parcial do hidrogênio é mantida constante $\mathrm{p}(\mathrm{H} 2)=5$ bar, enquanto a pressão parcial do monóxido de carbono é aumentada. Conforme a pressão parcial do monóxido de carbono aumenta gradativamente, enquanto o mesmo alimenta o reator, também aumenta o rendimento dos hidrocarbonetos de maior peso molecular. Isso é explicado uma vez que os hidrocarbonetos mais pesados precisam de mais moléculas de monóxido de carbono (CO) do que moléculas de hidrogênio (H2) e assim é possível construir cadeias carbônicas mais longas conforme demonstrado no gráfico (3.4).

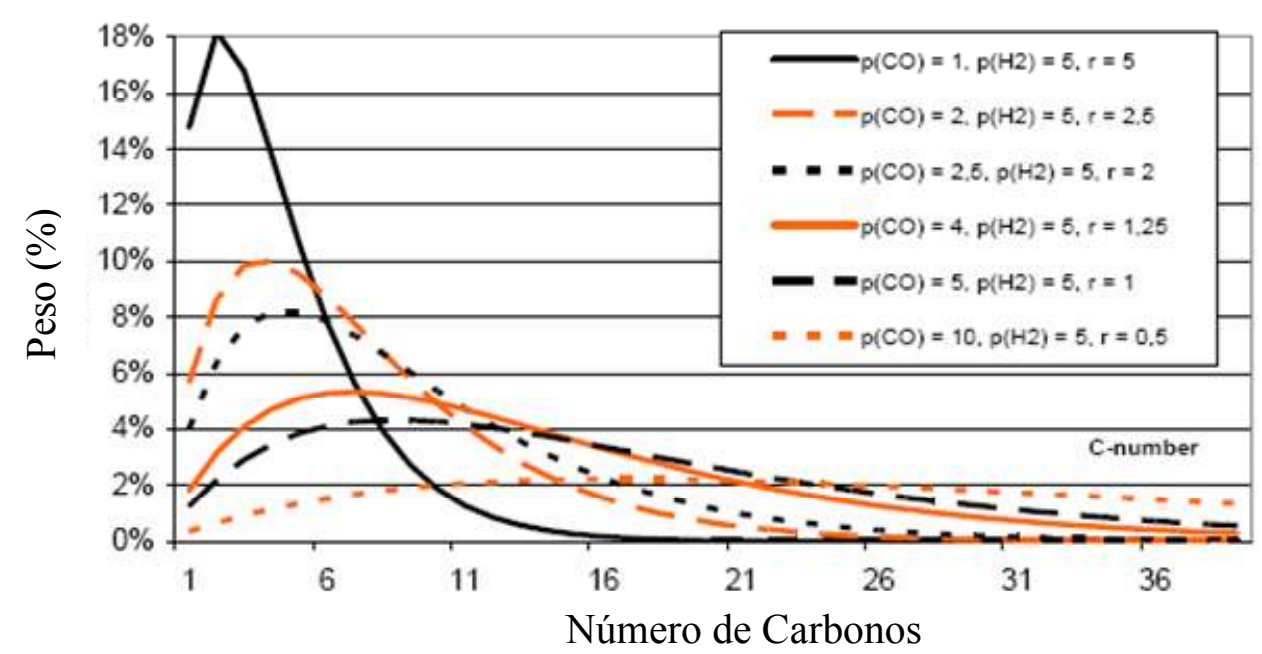

Gráfico 3.4 Variação da taxa (r) $\mathrm{H}_{2}:$ CO variando-se a pressão parcial do CO

Fonte: (Adaptado de VESSIA, 2006) 
É apontado por Hamelinck et al. (2003) que cadeias menores de hidrocarbonetos necessitam de mais hidrogênio - uma taxa próxima a 3 para a relação $\mathrm{H}_{2}$ : $\mathrm{CO}$ - enquanto as mais longas têm sua taxa próxima a 2 para a mesma relação, como demonstrado nas reações (3.15) a (3.19). Por exemplo, o etano $\left(\mathrm{C}_{2} \mathrm{H}_{6}\right)$ necessita de 2 átomos de carbono e 6 de hidrogênio; já o pentano requer 5 átomos de carbono e doze de hidrogênio, apresentando uma taxa $\mathrm{H}_{2}$ : $\mathrm{CO}$ de 2,4 em comparação com 3 para o etano.

$\begin{array}{lll}\mathrm{CO}+3 \mathrm{H}_{2} \rightarrow \mathrm{CH}_{4}+\mathrm{H}_{2} \mathrm{O} & \mathrm{H}_{2}: \mathrm{CO}=3,00 & \text { Reação (3.15) } \\ 2 \mathrm{CO}+5 \mathrm{H}_{2} \rightarrow \mathrm{C}_{2} \mathrm{H}_{6}+2 \mathrm{H}_{2} \mathrm{O} & \mathrm{H}_{2}: \mathrm{CO}=2,50 & \text { Reação (3.16) } \\ 3 \mathrm{CO}+7 \mathrm{H}_{2} \rightarrow \mathrm{C}_{3} \mathrm{H}_{8}+3 \mathrm{H}_{2} \mathrm{O} & \mathrm{H}_{2}: \mathrm{CO}=2,33 & \text { Reação (3.17) } \\ 4 \mathrm{CO}+9 \mathrm{H}_{2} \rightarrow \mathrm{C}_{4} \mathrm{H}_{10}+4 \mathrm{H}_{2} \mathrm{O} & \mathrm{H}_{2}: \mathrm{CO}=2,25 & \text { Reação (3.18) } \\ 5 \mathrm{CO}+11 \mathrm{H}_{2} \rightarrow \mathrm{C}_{5} \mathrm{H}_{12}+5 \mathrm{H}_{2} \mathrm{O} & \mathrm{H}_{2}: \mathrm{CO}=2,20 & \text { Reação (3.19) }\end{array}$

Em 1999 van der Laan apud Jun (2004) estudou a cinética existente entre as fases sólida e gasosa na síntese F-T utilizando catalisadores comerciais de $\mathrm{Fe}-\mathrm{Cu}-\mathrm{K}-\mathrm{SiO}_{2}$. Foi assim proposto um modelo de distribuição de produtos nomeado $\alpha$-Olefin Readsorption Product Distribution Model (ORDPM), o qual é capaz de combinar o modelo de re-adsorção das olefinas com a cinética do crescimento das cadeiras de hidrocarbonetos e sua terminação na mesma região do catalisador.

Com esse modelo, os experimentos mostraram um rendimento relativamente alto para o metano $\left(\mathrm{CH}_{4}\right)$, relativamente baixo para o etano $\left(\mathrm{C}_{2} \mathrm{H}_{6}\right)$, exponencialmente baixo para a taxa de conversão de olefinas para parafinas $(\mathrm{O} / \mathrm{P})$ e, ainda, a probabilidade de crescimento das cadeias poderia ser prevista. Entretanto, nesse modelo, um importante conceito, o da hidrogenação do monóxido de carbono (CO) - base para a construção das cadeias de hidrocarbonetos e para a formação dos monômeros - é tratado de forma distinta, separado do modelo em questão. 


\subsubsection{Mecanismos de formação e crescimento das cadeias de hidrocarbonetos}

O completo entendimento dos inúmeros processos que ocorrem numa superfície metálica catalítica na síntese FT possibilitará o desenvolvimento de melhores catalisadores, possibilitando assim um aprimoramento do processo em si e para tal, é preciso conhecer-se antes quais as espécies que se formam nessa superfície catalítica e como elas interagem entre si, formando, por conseqüência, as cadeias de hidrocarbonetos. Costuma-se aceitar que a formação das cadeias tem início pela dissociação do $\mathrm{CO}$ e em seguida sua hidrogenação para formar as espécies $(=\mathrm{CH}), \quad\left(-\mathrm{CH}_{2}-\right)$ e $\quad\left(-\mathrm{CH}_{3}\right)$, denominadas building blocks dos hidrocarbonetos. É consenso, segundo Ciobîcă; Ciobîcă et al. apud Jun (2004), entre os pesquisadores da síntese FT, que as reações essenciais podem ser tomadas como reações de polimerização de superfície e que a etapa onde as espécies $\mathrm{CH}_{\mathrm{x}}$ interagem umas com as outras (união C-C) para formar hidrocarbonetos de maior peso molecular é considerada sua etapa chave. Na figura (3.4), pode-se observar uma compilação de algumas das espécies, observadas experimentalmente em sua maioria, formadas na superfície catalítica dentro de um reator FT, todas formadas por reações entre o monóxido de carbono $(\mathrm{CO})$ e o hidrogênio $\left(\mathrm{H}_{2}\right)$ :

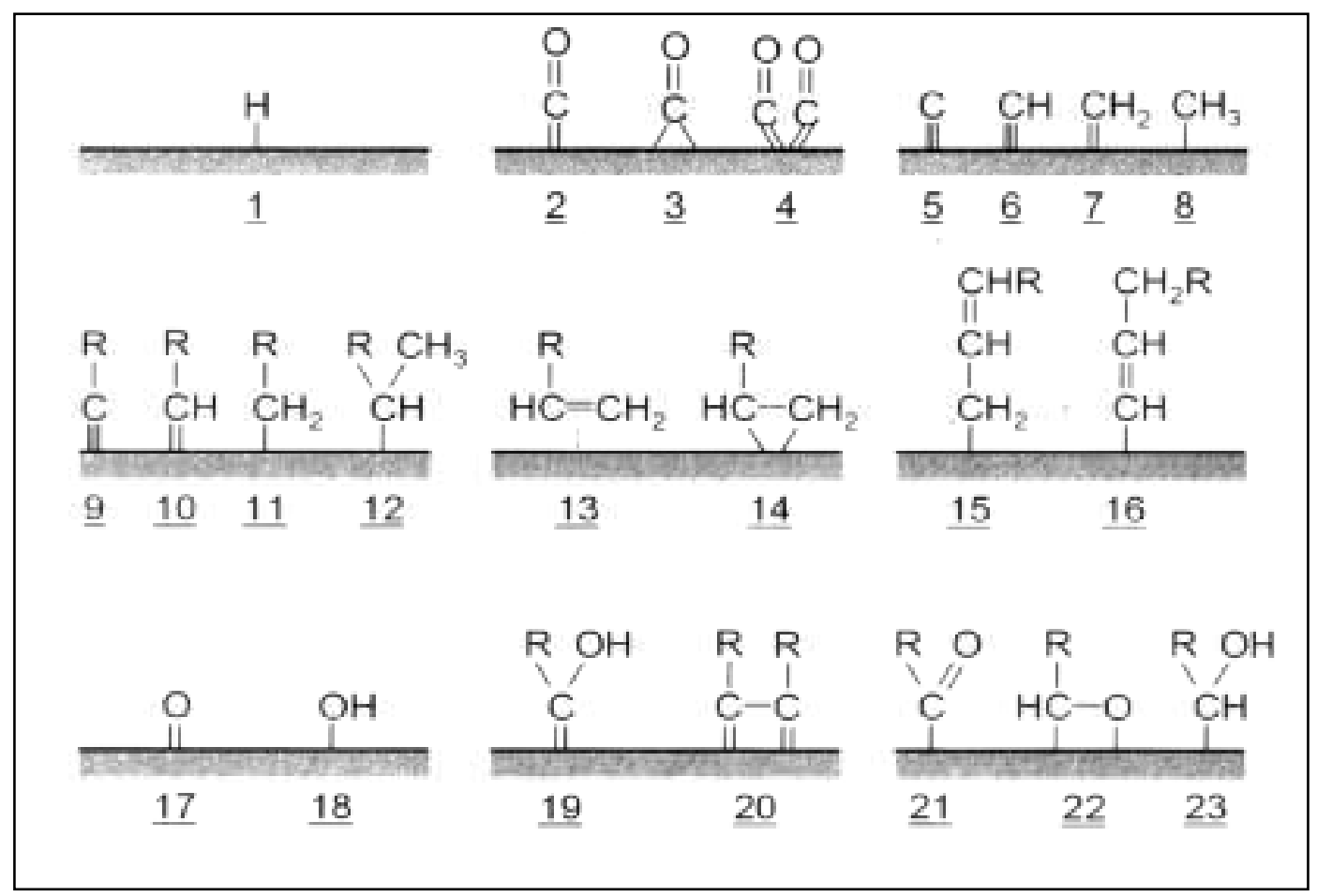

Figura 3.4 Espécies observadas sobre superfície catalítica na síntese FT.

Fonte: (STEYNBERG; DRY, 2004) 
$\mathrm{Na}$ espécie $\{\underline{1}\}$ observa-se a quimissorção do hidrogênio atômico que, sozinho, não apresenta reatividade significativa na síntese, em verdade, esse hidrogênio monoatômico reage com outras espécies ainda presentes na superfície catalítica. As espécies $\{\underline{2}\},\{\underline{3}\}$ e $\{\underline{4}\}$ representam três modos de ocorrer a quimissorção do monóxido de carbono (CO), respectivamente, atop, bridged e vicinal. O monóxido de carbono pode se dissociar, formando carbono $(\mathrm{C})$ e hidrogênio $(\mathrm{H})$ de superfície, respectivamente $\{\underline{5}\}$ e $\{\underline{17}\}$. A formação de carbono carbídico (átomo unitário de carbono) estável $\{\underline{5}\}$ foi observada somente na presença de catalisadores a base de ferro (Fe). A hidrogenação desse carbono leva ao grupo funcional trivalente metino, ou metilidino, $\{\underline{6}\}$; prosseguindo com a hidrogenação tem-se o grupo funcional bivalente metileno, também chamado de carbeno ou meteno, $\{\underline{7}\}$; e por fim o metil, ou metilo $\{\underline{8}\}$, grupo funcional monovalente. As espécies de $\{\underline{9}\}$ a $\{\underline{11}\}$ são originadas por reações entre as espécies $\{\underline{5}\},\{\underline{6}\}$ e $\{\underline{7}\}$ com as espécies $\{\underline{8}\}$ ou $\{\underline{11}\}$. A espécie $\{9\}$ foi identificada no processo de hidrogenação das olefinas, passando-as para parafinas $(\mathrm{O} / \mathrm{P})$; já a $\{\underline{12}\}$ pode ser a precursora da formação dos hidrocarbonetos ramificados, que pode ser formada pela reação da espécie $\{\underline{10}\}$ com um radical metil de superfície ou pela re-adsorção de uma $\alpha$-olefina. Foi observado por Cavalcanti et al. apud Steynberg e Dry (2004) que a readsorção do propeno $\left(\mathrm{C}_{3} \mathrm{H}_{6}\right)$ atua na formulação de compostos ramificados. A espécie $\{\underline{15}\}$, conhecida como propenil ou alil, e a espécie $\{\underline{16}\}$, conhecida como etenil ou vinil, são intermediárias de um dos mecanismos de crescimento de cadeias de hidrocarbonetos, o mecanismo conhecido como alquenil. O oxigênio de superfície $\{\underline{17}\}$ pode ser gerado pela dissociação do monóxido de carbono $(\mathrm{CO})$ decorrente de sua quimisorção, podendo este reagir com o hidrogênio adsorvido e gerar assim uma hidroxila de superfície $\{\underline{18}\}$ que, por sua vez, pode reagir com o monóxido de carbono e formar dióxido de carbono $\left(\mathrm{CO}_{2}\right)$; Johnston e Joyner apud Steynberg e Dry (2004) propuseram que o grupo funcional hidroxila $\{\underline{18}\}$ possui participação na formação de produtos oxigenados dentro do reator FT. As espécies $\{\underline{19}\}$ e $\{\underline{20}\}$ são intermediárias de outro mecanismo de crescimento de cadeias de hidrocarbonetos, o mecanismo enol contudo, ambas ainda não foram observadas experimentalmente. O oxigênio contido nas espécies $\{\underline{21}\}$ a $\{\underline{23}\}$ foi proposto como intermediário para o mecanismo conhecido como inserção de CO. Outrossim, como uma das variáveis de processo, pode ocorrer a adição de outras substâncias químicas no processo e assim influenciar o comportamento das reações. Algumas das espécies citadas acima podem, ainda, participar de transformações intermediárias entre uma espécie e outra, tornando o estudo dessas reações ainda mais complexo. Os principais mecanismos propostos para a síntese FT serão vistos a seguir. 


\subsubsection{Mecanismo alquil}

Segundo Steynberg e Dry (2004) o mecanismo alquil é, atualmente, aquele que descreve o crescimento das cadeias de hidrocarbonetos na síntese FT mais aceito dentre seus estudiosos, tendo ganhado notoriedade após a década de 1980. O início da cadeia se dá pela dissociação do monóxido de carbono, alvo da quimissorção, gerando carbono $\{\underline{5}\}$ e oxigênio $\{\underline{17}\}$. Esse oxigênio deixa a superfície catalítica ao reagir com hidrogênio $(\mathrm{H})$ adsorvido, formando água, ou reagir com monóxido de carbono adsorvido, formando dióxido de carbono. Já o carbono adsorvido sofre hidrogenação em reações consecutivas, formando as espécies de superfície $(=\mathrm{CH})\{\underline{6}\},\left(-\mathrm{CH}_{2}-\right)\{\underline{7}\}$ e $\left(-\mathrm{CH}_{3}\right)\{\underline{8}\}$, sendo o $\left(-\mathrm{CH}_{3}\right)$ o iniciador da cadeia e o metileno ou carbeno $\left(-\mathrm{CH}_{2}-\right)$ o monômero que, por sucessivas incorporações, será o construtor das cadeias de hidrocarbonetos, dando origem às $\alpha$-olefinas e n-parafinas como produtos primários; ou ainda compostos oxigenados, segundo Jonston e Joyner apud Steynberg e Dry (2004), formando álcoois - produtos da reação entre uma espécie alquil com uma hidroxila $(\mathrm{OH})\{\underline{18}\}$ de superfície. Em presença de catalisadores à base de ferro $(\mathrm{Fe})$ ocorre a formação do carbono em fase carbídica (C) $\{\underline{5}\}$, originando carbidos estáveis (MetalC), para posterior hidrogenação e formação do $\left(-\mathrm{CH}_{2}-\right)$, polimerizando em seguida; contudo isso não é observado em catalisadores à base de cobalto $(\mathrm{Co})$ ou rutênio $(\mathrm{Ru})$. De forma esquemática é possível observar as etapas que ocorrem na síntese FT, segundo o mecanismo alquil, na figura (3.5), assumindo que $\mathrm{R}$ é descrita por $\mathrm{R}=\mathrm{C}_{\mathrm{n}} \mathrm{H}_{2 \mathrm{n}+1} \operatorname{com} \mathrm{n} \geq 0$ (zero).

Jun (2004) sugere que, uma vez que o mecanismo alquil propõe que a reação de síntese é iniciada pela formação do radical metil $\left(-\mathrm{CH}_{3}\right)$ e o crescimento da cadeia ocorre pela inserção sucessiva do metileno $\left(-\mathrm{CH}_{2}-\right)$, na ligação metal-alquil (ligação organometálica), é possível descrever esse processo pela equação (3.10).

$\mathrm{C}_{\mathrm{n}} \mathrm{H}_{2 \mathrm{n}+1}+\left(-\mathrm{CH}_{2-}\right) \rightarrow \mathrm{C}_{\mathrm{n}+1}+\mathrm{H}_{2 \mathrm{n}+3}$

Equação (3.10)

No mecanismo alquil não está prevista a presença de hidrocarbonetos ramificados, contudo, Schulz et al. apud Steynberg e Dry (2004) propõem uma reação envolvendo as espécies de superfície metil $\left(-\mathrm{CH}_{3}\right)$ e alquilideno $\left(=\mathrm{CH}_{2}\right)$ de forma análoga à observada pelo mecanismo alquil. Esse alquilideno de superfície pode ser originado pela reação das espécies metil e metilidino $(\equiv \mathrm{CH})\{\underline{6}\}$. As espécies alquil ramificadas podem sofrer dessorção semelhante àquelas propostas para as espécies n-alquil, já demonstrado na figura (3.5). A 
presença de compostos ramificados é pequena mas deve ser observada, mesmo carecendo de reações mais detalhadas, hidrocarbonetos ramificados podem ocorrer dada a re-incorporação de olefinas re-adsorvidas, como o propeno $\left(\mathrm{C}_{3} \mathrm{H}_{6}\right)$ por exemplo, conforme pode ser observado na figura (3.6).

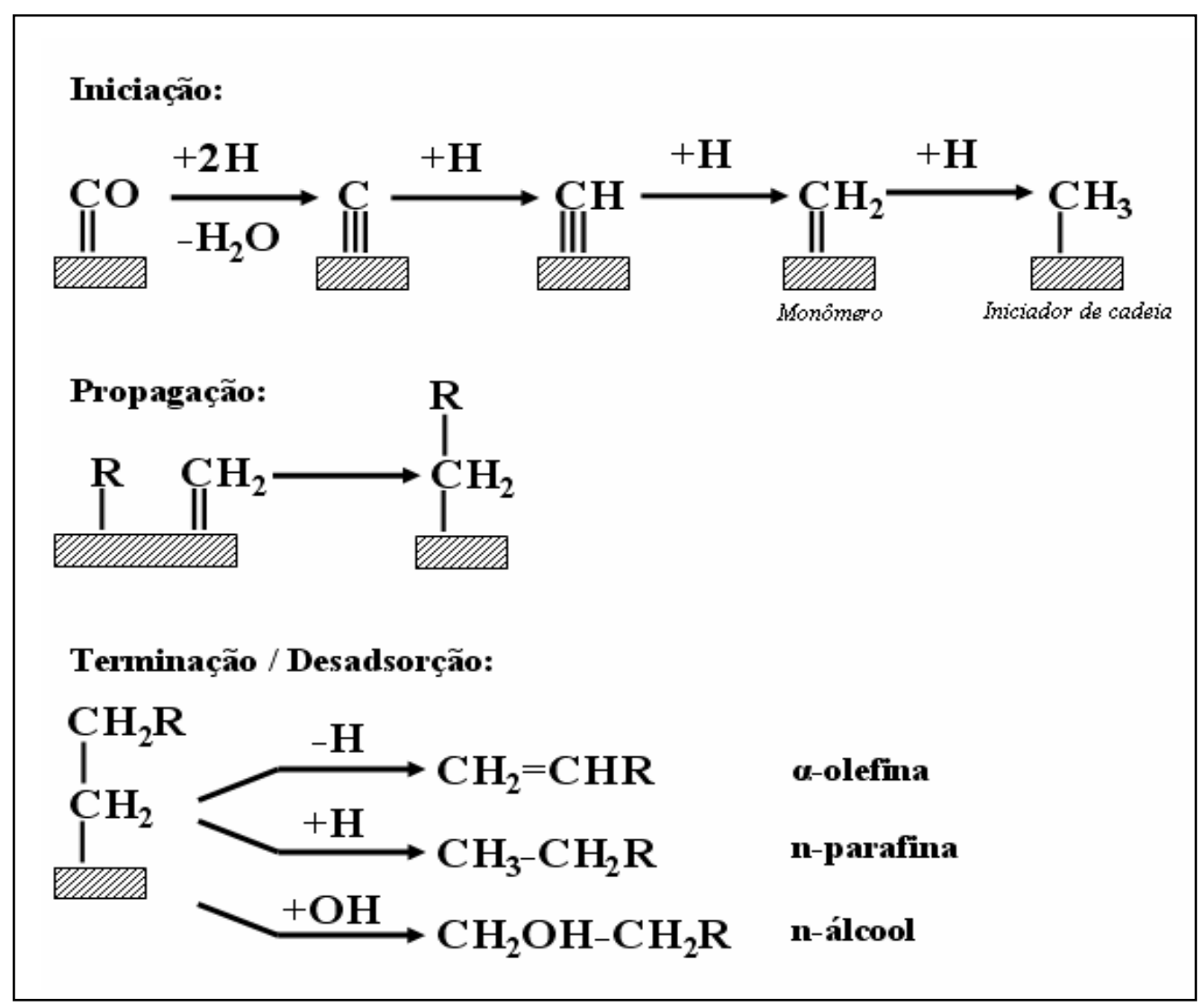

Figura 3.5 Síntese Fischer-Tropsch segundo mecanismo alquil.

Fonte: (Adaptado de STEYNBERG; DRY, 2004)

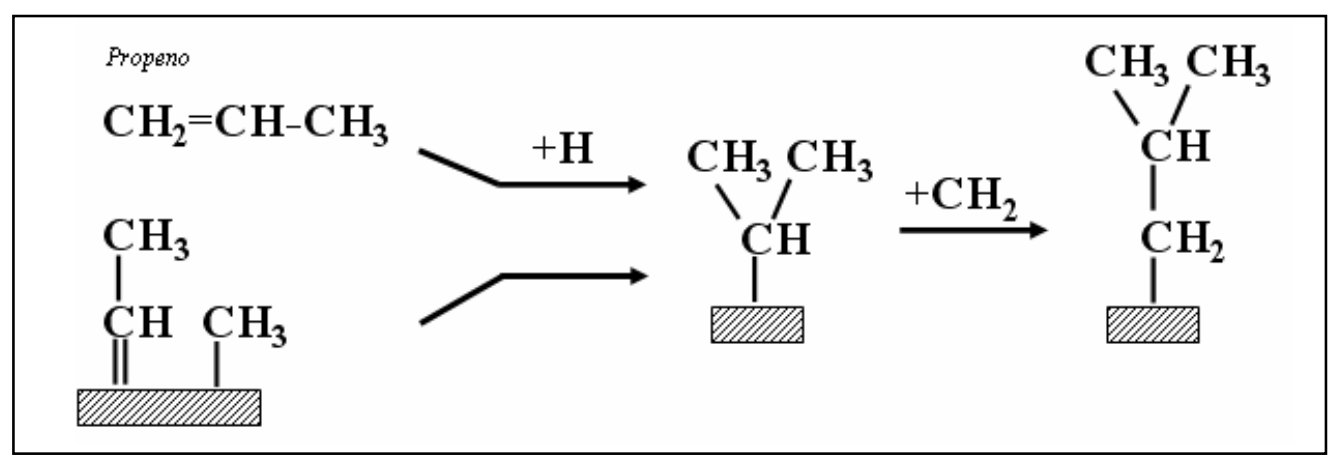

Figura 3.6 Proposição para formação de hidrocarbonetos ramificados no mecanismo alquil.

Fonte: (Adaptado de SCHULTZ et al. apud STEYNBERG; DRY, 2004) 


\subsubsection{Mecanismo alquenil}

Foi proposto por Maitlis apud Jun (2004) um mecanismo alternativo para predizer a formação das olefinas na síntese FT, negando a explicação proposta anteriormente pelo mecanismo alquil, onde a espécie metileno $\left(-\mathrm{CH}_{2}-\right)\{\underline{7}\}$ formava ligações entre os carbonos adsorvidos, gerando assim as cadeias de hidrocarbonetos. Para o mecanismo alquenil a adsorção do monóxido de carbono $(\mathrm{CO})$ e sua transformação em espécies de superfície $\mathrm{CH}_{\mathrm{x}}$ ocorre da mesma forma como ocorre no mecanismo alquil; contudo a primeira ligação C-C tem lugar pela ligação entre o metilidino $(\equiv \mathrm{CH})\{\underline{6}\}$ e o metileno $\left(-\mathrm{CH}_{2^{-}}\right)$para formarem a espécie de superfície vinil $\left(-\mathrm{CH}=\mathrm{CH}_{2}\right)$, tida como o iniciador da cadeia. A propagação da cadeia envolve a adição do metileno à espécie vinil (alquenil de superfície), formando a espécie de superfície alil $\left(-\mathrm{CH}_{2}-\mathrm{CH}=\mathrm{CHR}\right)\{\underline{16}\}$ que, em seguida, isomeriza (alil-vinil) formando um alquenil de superfície $\left(-\mathrm{CH}=\mathrm{CH}-\mathrm{CH}_{2} \mathrm{R}\right)$ como pode ser verificado na figura (3.7). A reação de crescimento prossegue de forma análoga até ocorrer a dessorção pela adição de um hidrogênio $(H)$, gerando assim uma $\alpha$-olefina; entretanto esse mecanismo falha ao tentar explicar a formação primária de n-parafinas, requerendo assim a existência de caminhos alternativos que o façam. Ciobîcă et al. apud Steynberg e Dry (2004) propõem que há, ainda, reações de isomerização de compostos intermediários alílicos (que ocorrem durante a isomerização de uma espécie alil de superfície) que podem, após a subseqüente isomerização alil-vinil e a reação com o metileno de superfície, gerar hidrocarbonetos ramificados.

\subsubsection{Mecanismo enol}

Foi proposto pelo Bureau of Mines dos E.U.A., conforme consta em Steynberg e Dry (2004), um conjunto de reações alternativas envolvendo espécies de superfície que contêm oxigênio, nesse caso, a função orgânica enol, que consiste em um alceno com um grupo hidroxila fixado em um dos carbonos que compõe a dupla ligação. De acordo com esse mecanismo, o monóxido de carbono, após quimissorção, ao ser hidrogenado, forma um enol de superfície $(=\mathrm{CH}-\mathrm{OH})$. É possível observar essas reações em reatores cuja taxa $\mathrm{H}_{2}: \mathrm{CO}=1 \mathrm{e}$ na presença de catalisadores à base de cobalto ou ferro. $\mathrm{O}$ crescimento das cadeias ocorre 
pela condensação da espécie enol e eliminação da água; já a formação de hidrocarbonetos ramificados pode ser proveniente da participação da espécie de superfície CH-R-OH. A terminação dessas cadeias ocorre pelo processo de dessorção, originando $\alpha$-olefinas e produtos oxigenados (aldeídos e álcoois). Nesse mecanismo a formação de n-parafinas ocorre, de forma secundária, pela hidrogenação das olefinas primárias formadas pois, para a formação primária de n-parafinas, seriam precisas reações alternativas ainda não conhecidas. $\mathrm{O}$ mecanismo enol é importante pois descreve a formação de ácidos na síntese FT, originados por reações secundárias envolvendo os aldeídos, como conseqüência da reação de Cannizzaro $^{3}$ e, posteriormente, a reação desses ácidos com os álcoois, formando ésteres, conforme indicado na figura (3.8).

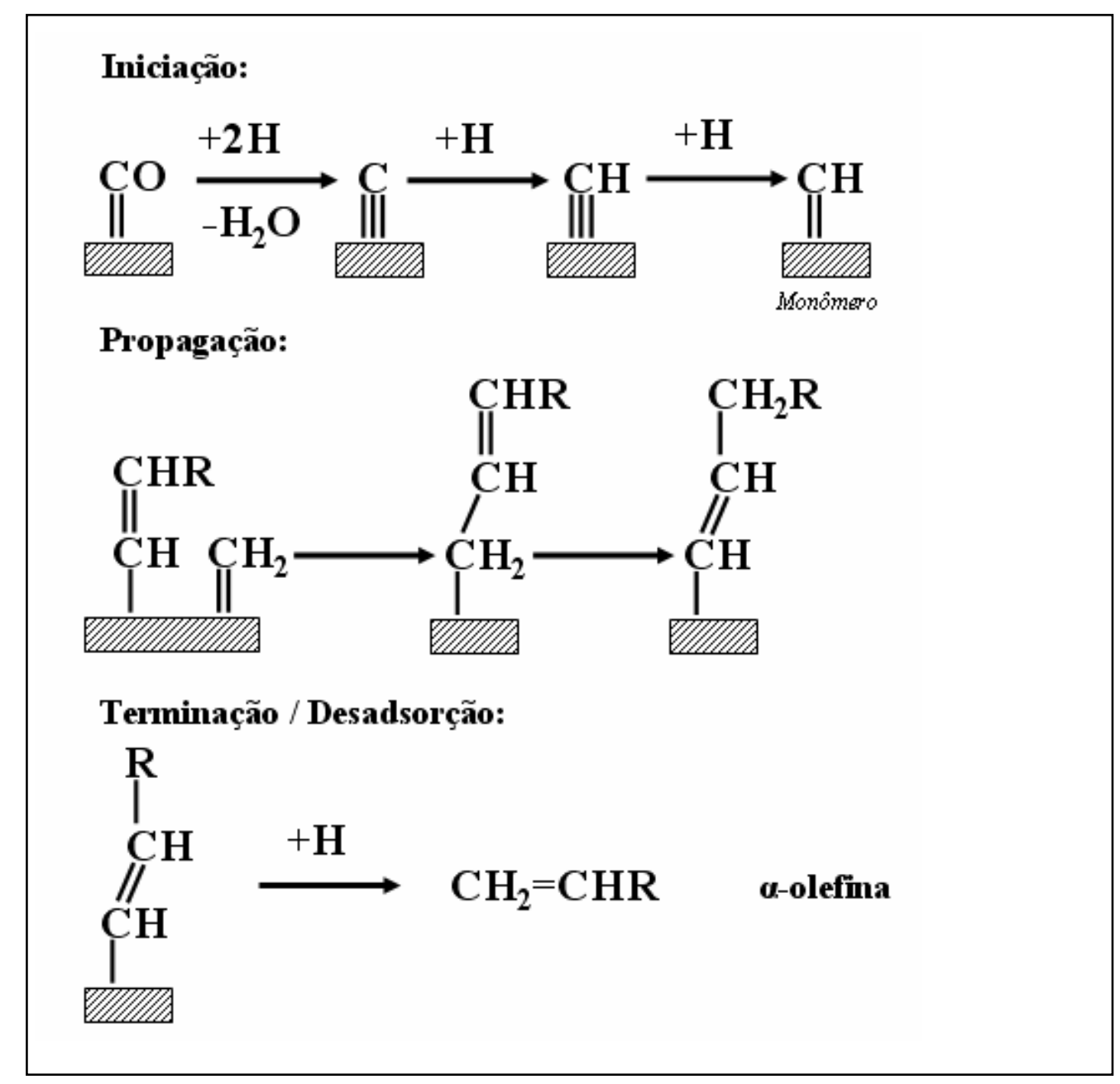

Figura 3.7 Síntese Fischer-Tropsch segundo mecanismo alquenil

Fonte: (Adaptado de STEYNBERG; DRY, 2004) 


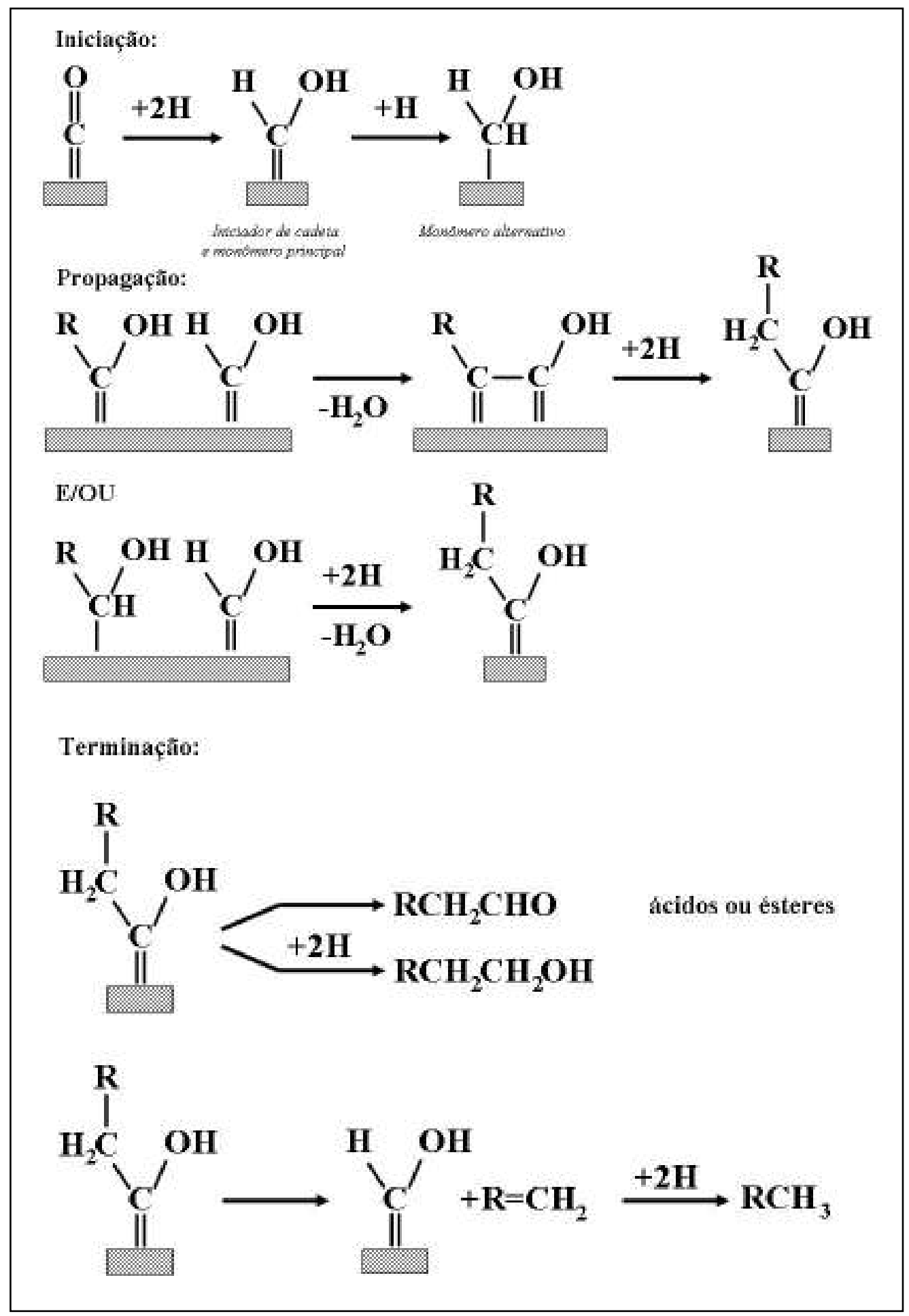

\section{Figura 3.8 Síntese Fischer-Tropsch segundo mecanismo enol}

Fonte: (Adaptado de STORCH et al. apud STEYNBERG; DRY, 2004)

\footnotetext{
3 Reação de auto-oxiredução descoberta pelo químico italiano Stanislao Cannizzaro (1826-1910) onde metade de um aldeído se oxida (auto-oxidação) formando sais e ácido carboxílico (ácido orgânico) e a outra metade se reduz (auto-redução) formando álcoois.
} 


\subsubsection{Mecanismo de inserção do CO}

Esse mecanismo tem sido alvo de estudos ao longo dos anos, tendo sido, inicialmente proposto por Sternberg, Wander e Roginski, e foi totalmente desenvolvido, algum tempo mais tarde, por Pichler e Schulz segundo apontam Steynberg e Dry (2004). Nesse mecanismo, o monóxido de carbono (CO) adsorvido é o monômero; o iniciador da cadeia continua sendo o a espécie metil $\left(-\mathrm{CH}_{3}\right)$ de superfície, porém sua formação difere um pouco daquela apresentada pelo mecanismo alquil. O crescimento da cadeia ocorre pela inserção do CO na ligação metalalquil originando uma espécie acilo de superfície. A eliminação do oxigênio nas cadeias leva ao crescimento das mesmas. A formação de $\alpha$-olefinas e n-parafinas é idêntica àquela proposta no mecanismo alquil, conforme demonstrado na figura (3.9), embora existam outras reações que tentem explicar a dessorção dessas espécies; as reações de terminação das cadeias podem envolver espécies de superfície que contenham hidrogênio, responsáveis pela formação de aldeídos ou álcoois - originadas pela adição de hidrogênio à espécie acilo de superfície ou pela eliminação do $\beta$-hidrogênio da espécie $\mathrm{R}-\mathrm{CHOH}$, formando a espécie enol de superfície $(\mathrm{R}=\mathrm{CH}-\mathrm{OH})$. Ainda é possível haver a formação de álcoois e cetonas. Jun (2004) resume que o mecanismo proposto assume que o crescimento da cadeia é iniciado pela adsorção do CO nos locais de reação que já contenham hidrocarbonetos intermediários e seguidos pelo processo de hidrogenação, segundo reações (3.11) a (3.13). Muitos pesquisadores acreditam que esse mecanismo é o principal caminho para a formação de compostos oxigenados.

$\mathrm{CO}+\mathrm{C}_{\mathrm{n}} \mathrm{H}_{2 \mathrm{n}+1} \rightarrow \mathrm{C}_{\mathrm{n}} \mathrm{H}_{2 \mathrm{n}+1}-\mathrm{CO}$

Reação (3.11)

$\mathrm{C}_{\mathrm{n}} \mathrm{H}_{2 \mathrm{n}+1}-\mathrm{CO}+\mathrm{H}_{2} \rightarrow \mathrm{C}_{\mathrm{n}} \mathrm{H}_{2 \mathrm{n}+1}-\mathrm{C}+\mathrm{H}_{2} \mathrm{O}$

Reação (3.12)

$\mathrm{C}_{\mathrm{n}} \mathrm{H}_{2 \mathrm{n}+1}-\mathrm{C}+\mathrm{H}_{2} \rightarrow \mathrm{C}_{\mathrm{n}} \mathrm{H}_{2 \mathrm{n}+1}-\mathrm{CH}_{2}$

Reação (3.13) 


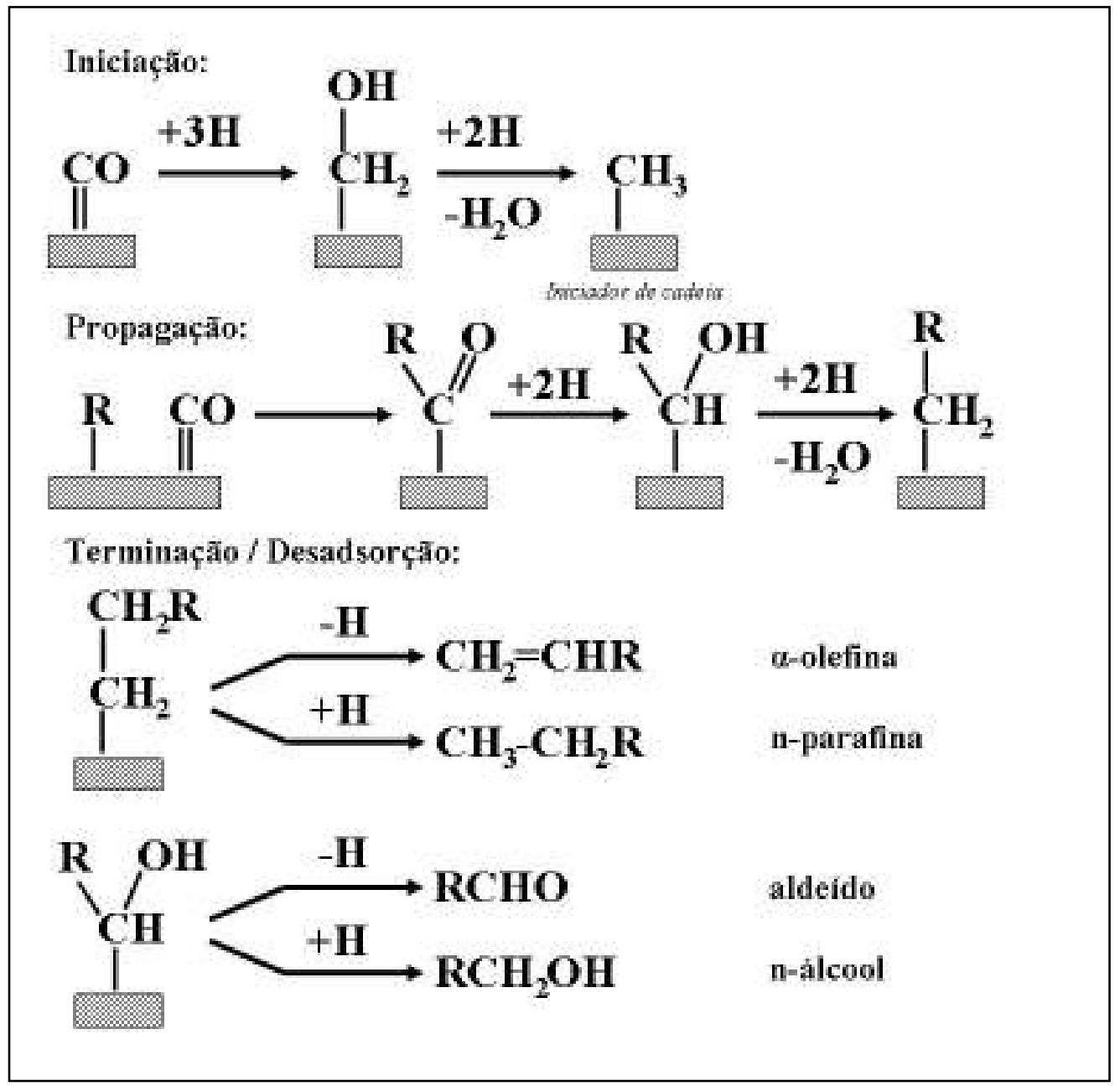

Figura 3.9 Síntese Fischer-Tropsch segundo mecanismo de inserção do CO

Fonte: (Adaptado de STEYNBERG; DRY, 2004)

Segundo Jun (2004) a maioria dos modelos organometálicos usados até o momento para tentar explicar as reações de síntese FT não utilizaram um catalisador em comum, como o ferro $(\mathrm{Fe})$ ou o cobalto $(\mathrm{Co})$ e algumas etapas do processo ainda não estão bem estabelecidas contudo, há um grande número de evidências que dão suporte aos modelos acima mencionados, mas os debates ainda continuam. Overett, Hill e Moss apud Jun (2004) realizaram um detalhado estudo dos mecanismos alquil e alquenil e os evidenciam para a síntese FT, sugerindo a possibilidade de que não somente um desses mecanismos opere para formação de todos os produtos observados (devido à grande gama das condições de operação) e sim que ambos os mecanismos possuem um importante papel, simultaneamente, sob as variadas condições. Recentemente Ciobîcă apud Jun (2004) realizou estudos a respeito do 
mecanismo de crescimento das cadeias de hidrocarboneto na síntese FT utilizando como catalisador o rutênio $(\mathrm{Ru})$ e fazendo uso de cálculos de química quântica, oferecendo assim uma descrição a nível atômico das reações dos radicais orgânicos e sua interação para formação das cadeias de hidrocarbonetos, obtendo resultados que demonstram que o (-CH-) é o mais estável de todos os intermediários de superfície que contêm um carbono $\left(\mathrm{C}_{1}\right)$ e costuma ser a unidade monomérica primordial para o crescimento das cadeias de hidrocarbonetos ao invés do, já mencionado, metileno $\left(-\mathrm{CH}_{2}-\right)$. Foi concluído que ambos os mecanismos propostos podem ocorrer em paralelo e as cadeias de hidrocarbonetos podem ser formadas por alguns ciclos de um mecanismo e alguns ciclos do outro. Isso irá depender do processo de hidrogenação e da ligação carbono-carbono (C-C).

Em 2002, Liu e Ho apud Jun (2004) estudaram a síntese FT e a estabilidade de muitos de seus intermediários chave, podendo, em seu trabalho, comparar muitos mecanismos de ligação carbono-carbono (C-C) de forma quantitativa como por exemplo o $\mathrm{C}-\mathrm{C}, \mathrm{C}-\mathrm{CH}, \mathrm{C}-$ $\mathrm{CH}_{2}, \mathrm{CH}-\mathrm{CH}, \mathrm{CH}-\mathrm{CH}_{2}, \mathrm{CH}_{2}-\mathrm{CH}_{2}$ e $\mathrm{CH}_{2}-\mathrm{CH}_{3}$. Os resultados apontaram que a ligação C-CH é a que possui as menores barreiras de formação enquanto a já conhecida $\mathrm{CH}_{2}-\mathrm{CH}_{3}$ é a que possui as maiores barreiras para sua formação. Eles sugerem que o crescimento das cadeias possa ocorrer pelo padrão C-CR ao invés do $\mathrm{CH}_{2}-\mathrm{CH}_{2} \mathrm{R}$. Desde a descoberta desse processo que o crescimento das cadeias tem sido extensivamente estudado e muitos resultados têm sido obtidos. Contudo, é importante mencionar que, mesmo com modelos matemáticos relativamente recentes, espécies de superfície já identificadas, reações secundárias estudadas e conhecimentos de produtos inertes - dióxido de carbono em baixas concentrações, metano e nitrogênio - ainda há controvérsias sobre os mecanismos de crescimento das cadeias de hidrocarbonetos.

\subsubsection{Catalisadores da síntese Fischer-Tropsch}

O cobalto $(\mathrm{Co})$, o ferro $(\mathrm{Fe})$, o níquel $(\mathrm{Ni})$ e rutênio $(\mathrm{Ru})$ catalisam a síntese FT. A seletividade, ou probabilidade de crescimento, é altamente dependente do catalisador utilizado, segundo Shell apud Hamelinck et al. (2003), assim como também depende da temperatura, pressões parciais dos reagentes e das substâncias inertes e também de qual tecnologia FT será utilizada. Ainda, segundo Bartholomew apud Hamelinck et al. (2003), a constante $\alpha$ é maior para os catalisadores à base de cobalto e rutênio em relação ao uso dos à 
base de ferro e os catalisadores à base níquel reagem com o monóxido de carbono sob elevadas pressões contudo, os líquidos formados não são atraentes em termos de processo. $\mathrm{O}$ rutênio é de alto interesse científico, sendo muito ativo, funcionando a uma temperatura de reação mais baixa $\left(150^{\circ} \mathrm{C}\right)$ e produzindo os hidrocarbonetos de maior peso molecular porém seu alto preço e suas limitadas reservas minerais o excluem de se tornar um produto de aplicação comercial.

Maretto e Krishna apud Hamelinck et at (2003) apontam que os catalisadores à base de cobalto também são capazes de gerar hidrocarbonetos de elevado peso molecular, além de promover a hidrogenação e produzir limitada quantidade de produtos oxigenados sendo que algumas de suas características permitem ao catalisador de cobalto atingir taxas de conversão superiores à dos catalisadores à base de ferro (ESPINOZA et al. apud HAMELINCK et al. 2003). Vessia (2006) expõe resultados experimentais obtidos em um reator laboratorial pressurizado a 30 bar, operado a $240{ }^{\circ} \mathrm{C}$ e que utiliza um catalisador à base de cobalto. É possível observar a distribuição dos produtos, no gráfico (3.5), sendo a abscissa o comprimento das cadeias de hidrocarbonetos e a ordenada a porcentagem em massa dos produtos (rendimento).

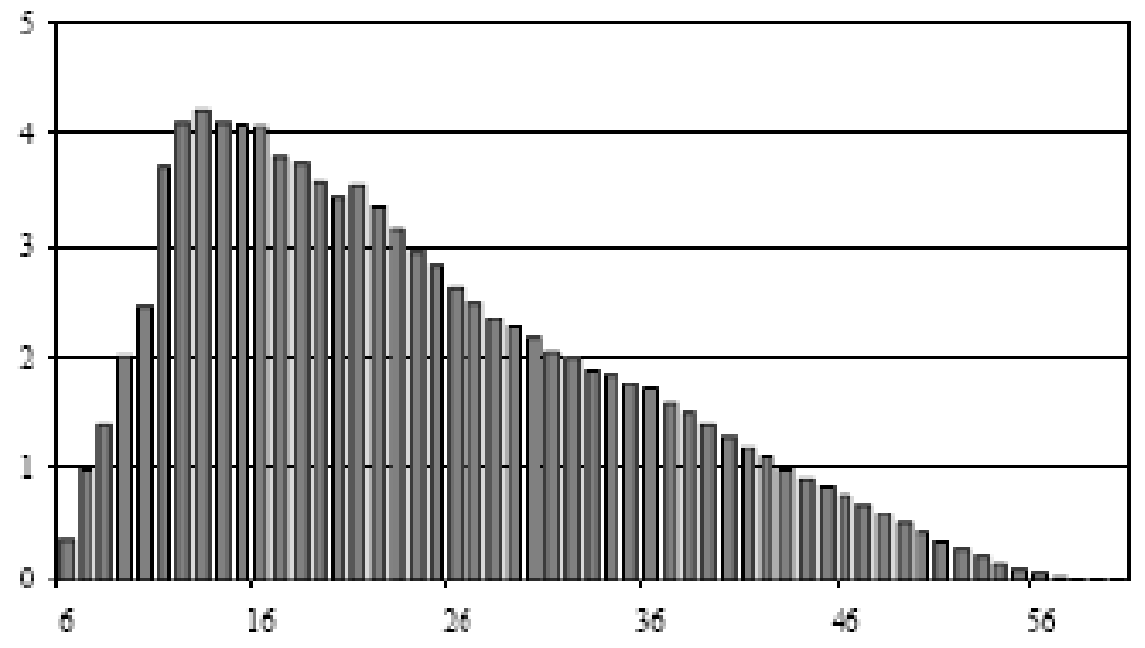

Gráfico 3.5 Distribuição de produtos com um catalisador à base de cobalto Fonte: (VESSIA, 2006)

É possível observar, no mesmo reator supracitado e nas mesmas condições de pressão e volume, operando a $280^{\circ} \mathrm{C}$, a distribuição dos produtos ao se utilizar um catalisador a base de ferro, indicado no gráfico (3.6), onde pode-se verificar a predominância de hidrocarbonetos na faixa de $\mathrm{C}_{10}-\mathrm{C}_{18}$, correspondente à faixa de inserção do óleo diesel. 


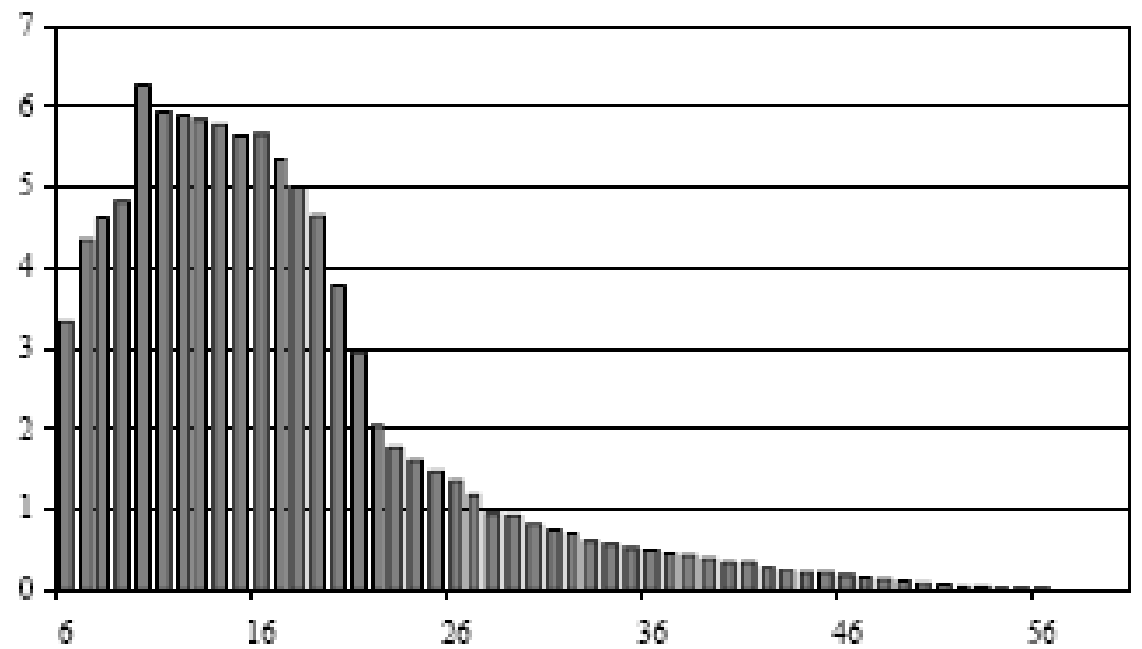

Gráfico 3.6 Distribuição de produtos com um catalisador à base de ferro (Fe)

Fonte: (VESSIA, 2006)

É apontado por Jager apud Hamelinck et al.. (2003) que, devido ao fato dos catalisadores à base de cobalto apresentarem uma melhor taxa de conversão, há cerca de $30 \%$ de redução do capital necessário para as instalações FT numa planta industrial. Esses catalisadores são muito mais dispendiosos do que os catalisadores à base de ferro e isso faz com que seja de suma importância que eles possuam uma longa vida de operação se comparados aos demais catalisadores metálicos em questão pois os mesmos podem perder sua atividade como resultado de oxidação, sinterização, incrustações ou algum tipo de envenenamento. É válido mencionar que a oxidação é relevante somente com catalisadores à base de ferro sob condições anormais de processo. Os catalisadores mencionados ainda podem ser envenenados por derivados do enxofre. Sob condições normais de operação na síntese FT há pouca deposição de carbono quando são utilizados catalisadores à base de níquel, cobalto ou rutênio uma vez que, quando se trata dos à base de ferro, em condições cuja temperatura encontre-se acima de $550 \mathrm{~K}\left(277^{\circ} \mathrm{C}\right)$, há depósito de carbono em decorrência da reação de Boudouard.

A temperatura exerce uma influência consistente para todos os catalisadores FT. Altas temperaturas reduzem o comprimento médio das moléculas nos diversos produtos, favorece a formação do metano assim como favorece a deposição carbono e, conseqüentemente, a desativação do catalisador (em particular dos catalisadores à base de ferro). Por ser tratar de um processo fortemente exotérmico é essencial manter as condições isotérmicas do processo para assegurar a alta taxa de reação sem nenhuma adversidade qualquer que possa influenciar os produtos de reação. A taxa $\mathrm{H}_{2}$ : $\mathrm{CO}$ também possui influência nos catalisadores sendo 
relevante mencionar que uma vez que a taxa de consumo de $\mathrm{H}_{2}$ :CO varia ao longo do reator, a seletividade será diferente nas diferentes áreas do reator; ao se diminuir a taxa de $\mathrm{H}_{2}: \mathrm{CO}$, diminui-se também a atividade do catalisador, reduzindo assim a produtividade do processo.

Por fim, Steynberg e Dry (2004) afirmam que, após investigada a seletividade dos produtos FT em função do tempo de permanência dentro do reator, é possível evidenciar que esse regime de formação de cadeias se comporta de forma peculiar uma vez que os catalisadores utilizados são re-estruturados sob a presença dos reagentes, produtos finais e produtos intermediários, indicando que a "verdadeira catálise" é formada e se torna estável somente in situ, ou seja, enquanto as reações de adsorção, propagação, dessorção e readsorção ocorrem, fazendo com que, dessa forma, modelos cinéticos teóricos nunca retratem, de fato, o comportamento das espécies na superfície catalítica; e mesmo que os catalisadores sejam preparados, inicialmente juntos, eles apresentarão comportamentos distintos em relação à sua estabilidade, se utilizados em escala laboratorial e em escala industrial - principalmente catalisadores à base de ferro utilizados em processos LTFT - e muitos pesquisadores acreditam que o futuro da síntese FT dependerá da nano catálise. 


\section{COMBUSTÍVEIS}

Desde o início da civilização, a queima de combustiveis vem sendo utilizada como fonte de luz e energia e, provavelmente, continuará pelo menos como fonte de energia, ainda por muitos anos. A combustão foi primeiramente usada para iluminação, aquecimento $e$ cozimento de alimentos, porém para finalidades práticas, um progresso muito rápido só ocorreu após a Revolução Industrial, quando muitas indústrias surgiram como um resultado desta evolução.

(Roberto Garcia)

Em agosto de 1859 o norte-americano Edwin Laurentine Drake perfurou o primeiro poço para a procura do petróleo (a uma profundidade de $21 \mathrm{~m}$ ), na Pensilvânia. O poço revelou-se produtor e a data passou a ser considerada a do nascimento da moderna indústria petrolifera.

(Desconhecido)

\subsection{Conceituando combustível}

Combustível pode ser entendido de formas diferentes de acordo com o a época e o contexto no qual é definido, podendo ser tomado como uma substância capaz de produzir calor pela combinação com o oxigênio; o Centro de Educação Tecnológica de Minas Gerais, de modo geral, denomina combustível como sendo qualquer corpo cuja combinação química

com outro seja exotérmica (informação de aula) ${ }^{1}$. Dentre muitas outras definições adequadas, talvez aquela apresentada no artigo "Fuel" (2005), disponibilizado pela NASA, seja a que traduz de forma verossímil o conceito nos tempos modernos: "fuel is a material that makes energy" fazendo sentido entender-se então, apresentando uma possível tradução, que “combustível é uma substância capaz de produzir energia”. Largamente utilizado em todos os ramos da atividade humana, o combustível, apresentado de inúmeras formas distintas, está sempre presente quando se deseja produção de energia térmica, sendo conhecido desde a mais remota antiguidade, sua utilização pelo homem foi um dos maiores fatores do desenvolvimento da raça humana. Os combustíveis, em sua maioria, são constituídos 
majoritariamente de três elementos químicos: o carbono $(\mathrm{C})$, o hidrogênio $(\mathrm{H})$ e o oxigênio (O), que se acham agrupados sob diferentes formas e que vêm acompanhados de algumas substâncias que podem constituir impurezas. Há combustíveis sólidos, líquidos e gasosos; são exemplos de combustíveis: o carvão mineral, a lenha, o petróleo e seus derivados, o gás natural, a biomassa (em suas mais diversas formas), o lixo doméstico e alguns elementos radioativos. Dentre os combustíveis sólidos um dos mais importantes é o carvão. Existem diversos tipos de carvão e todos são resultado da decomposição lenta, durante milhões de anos, de matérias vegetais; constituem os restos de espessas florestas, principalmente do Período Carbonífero, na Era Paleozóica, cerca de 280 milhões de anos A.C., que foram cobertas por grandes camadas de terra e rochas através das eras. A carbonização se produziu principalmente pela ação do calor e da pressão exercida pela massa de rochas e terra que as cobriam e assim o carvão mineral é classificado de acordo com suas propriedades físicas e químicas em: antracito, turfa, hulha e linhita.

O antracito é o carvão de formação mais antiga, possuindo brilho metálico e uma pequena porcentagem de produtos voláteis. A turfa corresponde ao primeiro estágio da carbonização como resultado da decomposição parcial de vegetais em lugares muito úmidos, sendo mole, leve e de cor escura; dos combustíveis é o menos usado pois é o de menor poder calorífico. A linhita tem maior poder calorífico que a turfa, contém maior quantidade de hidrocarbonetos que a hulha, é de cor negro-pardacenta e requer grande cuidado em seu manuseio e armazenamento, pois se decompõe rapidamente em contato com a atmosfera. A hulha é a principal variedade de carvão mineral. É um carvão duro, de cor negra ou parda escura, formada de carbono e de vários outros compostos desse elemento e que, quando aquecida em uma atmosfera limitada entre $1.000^{\circ} \mathrm{C}$ e $1.300{ }^{\circ} \mathrm{C}$ em presença de corrente de ar, sem que haja combustão, produz o coque e outros subprodutos como o alcatrão. O coque, substância porosa, celular e heterogênea, de cor cinza, de alto teor de carbono, é usado nas fundições e alto-fornos para operações industriais como a produção de aço, por exemplo.

Ainda destaca-se a lenha, cuja importância foi significativamente diminuída, apesar de ainda ser utilizada em grande escala em locais de poucos recursos e cujos propósitos vão desde o cozimento de alimentos até o aquecimento de ambientes. É predominante em muitos lugares do continente africano como fonte primária de energia uma vez que, pela sua queima, sob condições específicas, é obtido o carvão vegetal, de poder calorífico superior.

\footnotetext{
${ }^{1}$ Material extraído da disciplina Máquinas Térmicas do curso Técnico em Mecânica do Centro de Educação Tecnológica de Minas Gerais - CEFET-MG.
} 
Os combustíveis líquidos são, em sua maioria, óleos minerais ou derivados desses óleos, sendo o principal deles o petróleo, encontrados na formam de mananciais ou em grandes profundidades, em depósitos entre as rochas sedimentares, estejam elas em terra ou nas regiões oceânicas. São altamente inflamáveis e compostos de diversos hidrocarbonetos. O petróleo bruto é submetido à destilação fracionada e dissociação térmica (cracking), a fim de se obter vários derivados líquidos, todos eles de grande utilização nos mais variados segmentos de mercado. Alguns dos principais são, a gasolina $\left(\mathrm{C}_{8} \mathrm{H}_{18}\right)$, o querosene $\left(\mathrm{C}_{12} \mathrm{H}_{26}\right) \mathrm{e}$ o óleo diesel $\left(\mathrm{C}_{13} \mathrm{H}_{28}\right)$ - fórmula molecular média apresentada em Venturi et al. (2002). Também podem ser obtidos por outros meios com a destilação do xisto betuminoso ou pela hidrogenação do carvão.

A gasolina é um combustível constituído basicamente por hidrocarbonetos e, em menor quantidade, por produtos oxigenados. É utilizada como combustível de automóveis e aviões, tendo sido, juntamente com o óleo diesel, um dos fatores do progresso industrial, obtido a partir do final do século XIX. O óleo diesel também é obtido pela destilação fracionada do petróleo depois que a gasolina, o querosene e os produtos leves são removidos do óleo cru, sendo utilizado em motores de combustão interna de ignição por compressão empregados nas mais diversas aplicações, tais como: automóveis, furgões, ônibus, caminhões, pequenas embarcações marítimas, máquinas de grande porte, locomotivas etc. Vários tipos de óleos diesel são obtidos, mas em geral os mais leves são usados em pequenos motores e de alta rotação, enquanto que os motores de baixa e média rotação usam óleos mais pesados. $\mathrm{O}$ querosene puro, ou misturado com outros produtos da destilação do petróleo, é utilizado em usinas e como base para combustíveis de motores a jato. É um composto formado por uma mistura de hidrocarbonetos alifáticos, nafênicos (cilo-parafínicos) e aromáticos. Dadas suas inúmeras características, este combustível caracteriza-se por possuir uma excelente solvência, sendo amplamente utilizado na indústria e em meio doméstico, já tendo sido, no passado, empregado como agente de iluminação em vielas públicas. Há ainda o etanol, também conhecido como álcool etílico, que é uma substância obtida da fermentação de açúcares ou amido e cuja matéria-prima pode ser a cana-de-açúcar, o milho, a beterraba, dentre outras ainda em fase de pesquisa. No Brasil esse combustível vem sendo utilizado em motores de explosão, ciclo Otto, constituindo um mercado potencial e em desenvolvimento para um combustível obtido de maneira renovável e sustentável, estabelecendo assim uma indústria de química de base, sustentada na utilização de biomassa de origem agrícola.

O gás natural provém de depósitos petrolíferos e, assim como o petróleo, também é uma mistura de hidrocarbonetos resultantes da decomposição de matérias orgânicas, contudo 
esses hidrocarbonetos encontram-se no estado gasoso à temperatura e pressão ambientes e vêm sendo utilizados largamente como combustível na forma de GNV (Gás Natural Veicular) e em usinas termelétricas. Destaca-se ainda o combustível nuclear que pode ser tido como um material suscetível de sofrer reação em cadeia provocada pelo bombardeamento de nêutrons e posterior liberação de grandes quantidades de energia; alguns dos combustíveis nucleares mais conhecidos e utilizados é o urânio 235; há também o plutônio 239 e o tório 232. O combustível nuclear possui um potencial energético gigantesco e sua utilização tem estado em evidência nos últimos anos por muitos governos mundiais, que discutem suas vantagens frente a questões de segurança global e sócio-ambientais. Há ainda uma grande diversidade de combustíveis a serem estudados e utilizados podendo estes se apresentarem em variadas formas e composições, como as pesquisas que utilizam o hidrogênio $(H)$ em células a combustível ao invés de utilizar sua combustão direta; dentre as formas de biomassa existem inúmeras possibilidades - tem-se os chamados combustíveis da segunda geração - e constantes pesquisas estão sempre a buscar por combustíveis alternativos que atendam, cada vez mais e da melhor forma possível, a demanda da sociedade por uma forma de progresso que possa ser considerada sustentável dentro dos padrões por ela mesma estabelecidos.

\subsection{Octanagem, Número e Índice de Cetano}

Para se compreender melhor um combustível é preciso conhecer os conceitos de octanagem e número de cetano, que se apresentam como características fundamentais para a classificação dos combustíveis gasolina e óleo diesel, respectivamente. A octanagem pode ser definida como sendo o índice de resistência à detonação de um combustível no motor de explosão interna do ciclo Otto, sendo a gasolina o combustível mais utilizado; já o número de cetano é capaz de indicar a qualidade da detonação de um combustível num motor do ciclo Diesel, tendo influência direta na partida do motor e no seu funcionamento sob carga e sendo o óleo diesel o principal combustível utilizado nesses motores. Começando pela gasolina, seus parâmetros de qualidade mais críticos referem-se justamente às suas características antidetonantes e o índice de octano, ou octanagem, ou ainda NO, que é uma medida da capacidade do combustível resistir à detonação espontânea, ou seja, é a medida das propriedades antidetonantes da gasolina e indica sua capacidade de evitar que a combustão da mistura ar/combustível ocorra antes do ponto, o que prejudica o rendimento do motor - a 
detonação é mais conhecida como batida de pino por se assemelhar a um barulho metálico. Um combustível com maior octanagem tem melhor poder de combustão e resiste a altas pressões no interior dos cilindros do motor, sem sofrer detonação. Os projetistas de motores levam em conta a octanagem do combustível utilizado para determinar a taxa de compressão, curvas de avanço de ignição e tempo de injeção mais adequados para o projeto em desenvolvimento. O poder antidetonante é tido como um dos mais relevantes parâmetros para avaliar a qualidade da gasolina automotiva, sendo determinado, comumente, por um equipamento padrão consistindo, basicamente, de um motor monocilíndrico cuja taxa de compressão pode ser ajustada conforme necessidade e há um dispositivo que mede o número de batidas do motor por unidade de tempo determinada - conhecido pelo termo em inglês knockmeter, que foi desenvolvido pelo Cooperative Fuel Research Committee (CFR).

Para se determinar a octanagem da gasolina existem dois métodos: o MON (Motor Octane Number) que avalia a resistência do combustível à detonação quando está sendo utilizado nas condições de funcionamento mais exigentes e em rotações mais elevadas, como acontece nas subidas de ladeira com marcha reduzida, alta velocidade e nas ultrapassagens (quando a aceleração é aumentada mesmo já estando o carro em alta velocidade). O RON (Research Octane Number) avalia a resistência da gasolina à detonação sob condições suaves de trabalho e a uma rotação menor do que aquela avaliada pela octanagem MON, como ocorre, o veículo realiza o "arranque" no sinal, por exemplo. IAD (Índice Antidetonante) é a média dos anteriores. (informação online) ${ }^{2}$

A relação entre os métodos MON e RON pode ser expressa pela equação (4.1) na forma do IAD. De forma comparativa, a resistência à detonação de duas ou mais variedades de gasolinas deverá ser feita somente se for considerado o mesmo padrão de desempenho, seja ele o MON, o RON ou Índice Antidetonante (IAD), sendo que o combustível é classificado segundo esse último em número de octanas (NO). Quanto maior for o NO, mais antidetonante será a gasolina (maior será seu IAD) e, por conseguinte, maior será a sua capacidade de suportar altas compressões sem sofrer a detonação, sendo esse índice uma relação de equivalência à resistência de detonação de uma mistura percentual do composto iso-octano (2,2,4 trimetilpentano) e do n-heptano. (PETROBRAS - DISTRIBUIDORA S.A.).

$I A D=\frac{M O N+R O N}{2}$

Equação (4.1)

\footnotetext{
${ }^{2}$ Material disponibilizado pela Pontífice Universidade Católica (PUC) do estado do Rio de Janeiro. Disponível online em sua Biblioteca Virtual sob Certificação Digital No 0114349/CA. Disponível em : <http: ww.maxwell.lambda.ele.puc-rio.br/cgi-bin/PRG_0599.EXE/4432_5.PDF?NrOcoSis=10585\&CdLinPrg=pt> Acesso em 19 de junho de 2008
} 
O iso-octano é especialmente resistente à compressão devido à estrutura de suas moléculas e na gasolina a presença desse componente evita o problema da detonação ou batida de pino - fenômeno que acontece quando o combustível explode durante a compressão, e não no momento em que a vela solta a faísca dentro do cilindro, comprometendo assim o rendimento da operação. Com mais iso-octano, ou seja, mais octanagem, é possível usar taxas de compressão mais altas no motor, e com isso obter um maior rendimento, assim uma gasolina de octanagem 87, por exemplo, apresenta resistência de detonação equivalente a uma mistura de $87 \%$ de iso-octano e $13 \%$ de n-heptano - contudo são possíveis valores superiores a 100 para a octanagem: uma gasolina com octanagem 120 apresentará, na mesma escala, uma resistência 20\% superior à do iso-octano. De acordo com Best (2002) a octanagem não possui relação direta com a qualidade da gasolina entretanto, quando se trata de motores mais potentes, que requeiram maiores compressões, por conseqüência, os combustíveis mais resistentes à ignição espontânea se farão necessários, contudo é importante mencionar que potência e um rendimento ótimo são sempre obtidos a partir de combustíveis cuja octanagem seja compatível com o projeto do motor e suas limitações. As fórmulas estruturais para o nheptano e para o iso-octano, ressaltando sua diferença, podem ser observadas na figura (4.1).

\section{$\mathrm{CH}_{3}-\mathrm{CH}_{2}-\mathrm{CH}_{2}-\mathrm{CH}_{2}-\mathrm{CH}_{2}-\mathrm{CH}_{2}-\mathrm{CH}_{3}$ n-heptano}

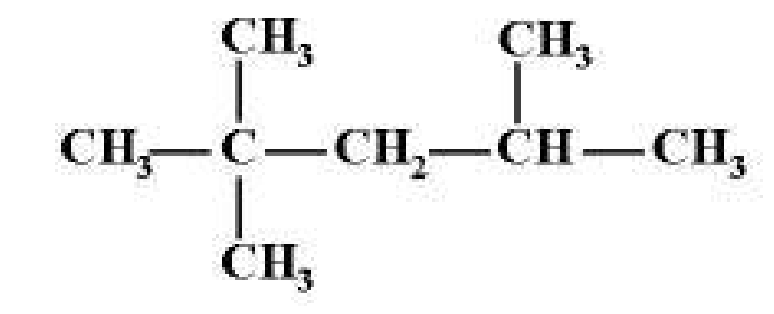

iso-octano

\section{Figura 4.1 Fórmulas estruturais para o n-heptano e o iso-octano}

Fonte: (Elaboração própria)

Antunes (2001) aponta que a determinação do NO objetiva analisar a cinética de propagação da chama durante o processo de queima do combustível, uma vez que essa deverá ser a mais homogênea possível para assim evitar possíveis variações na velocidade de progressão ao longo dos cilindros do motor, o que poderia provocar uma perda de potência e gerar um baixo rendimento, além de danos mecânicos ao motor, dependendo de sua 
intensidade. Para se definir o NO foi preciso criar uma escala variando de 0 (zero), que corresponde a um combustível que tem o mesmo poder antidetonante do n-heptano, a 100 (cem), que corresponde a um combustível com características iguais às do iso-octano. Contudo, alguns tipos de compostos, algumas vezes modificados pela adição de outras substâncias, têm um poder antidetonante maior que o iso-octano e, portanto, possuem octanagem superior 100 como, por exemplo, os hidrocarbonetos aromáticos puros, éteres e alcoóis de baixo peso molecular. Em termos ilustrativos, uma gasolina cujo NO é igual a 90, por exemplo, apresenta a mesma resistência à detonação por compressão que uma mistura com $90 \%$ de iso-octano e $10 \%$ de n-heptano, sendo que a diferença no IAD entre os diversos tipos de gasolina é resultante de sua composição química e, como regra geral, os alcanos normais (n-parafinas) apresentam valores de NO que diminuem à medida que seu peso molecular aumenta; tem-se ainda as iso-parafinas que apresentam melhores características antidetonantes do que as n-parafinas pois quanto mais ramificadas forem suas estruturas, maior será o NO daquele hidrocarboneto. Na tabela (4.1) pode-se verificar a relação existente entre a composição química de alguns compostos orgânicos, sua estrutura molecular e sua respectiva octanagem - destaque para o n-pentano e o iso-octano, anteriormente mencionados como referenciais (padrões) para a determinação do NO na gasolina.

Tabela 4.1 Relação entre diferentes hidrocarbonetos e octanagem (NO).

\begin{tabular}{||l|c|l|c|l|c|l|c||}
\hline Parafinas & NO & Iso-Parafinas & NO & Olefinas & NO & Aromáticos & NO \\
\hline \begin{tabular}{l} 
n-pentano \\
\hline n-hexano
\end{tabular} & 64 & 2-metilpentano & 80 & 2-metilbuteno-2 & 158 & benzeno & 94 \\
\hline n-heptano & 20 & 3-metilpentano & 83 & 3-metilpenteno-2 & 153 & tolueno & 118 \\
\hline n-octano & $\mathbf{0}$ & 2-metilhexano & 41 & ciclopentano & 148 & etilbenzeno & 115 \\
\hline n-decano & -17 & 3-metilhexano & 56 & metilciclopentano & 165 & 3-etiltolueno & 150 \\
\hline \begin{tabular}{l} 
n-dodecano \\
\hline
\end{tabular} & -39 & 2,2-dimetilpentano & 91 & 1,3-ciclopentadieno & 183 & 1,3,5-trimetilbenzeno & 153 \\
\hline
\end{tabular}

Fonte: (Adaptado de ANTUNES, 2001)

De acordo com o Serviço Brasileiro de Respostas Técnicas (SBRT, 2007) para a regulagem do índice de octano, ou número NO, podem ser utilizadas substâncias que são comumente conhecidas como aditivos, como por exemplo, o chumbo tetraetila (CTE) cuja fórmula é $\mathrm{Pb}\left(\mathrm{C}_{2} \mathrm{H}_{5}\right)_{4}$, ou o chumbo tetrametila $(\mathrm{CTM})$ de fórmula $\mathrm{Pb}\left(\mathrm{CH}_{3}\right)_{4}$, adicionados em quantidades de 0,08 a $0,09 \mathrm{~cm}^{3}$ por litro, e desempenham o papel de aditivos, aumentando a octanagem de 5 a 7 unidades. Desde 1989, no Brasil - e em alguns outros países - estas 
substâncias estão proibidas devido a sua alta toxicidade em meio sócio-ambiental. Como uma alternativa viável utiliza-se o álcool etílico carburante, etanol presente no mercado para uso automotivo, que pode ser adicionado como aditivo à gasolina, sendo que esse álcool é do tipo anidro e não hidratado - combustível comercial encontrado nos postos de abastecimento. A diferença entre ambos está na presença de água, uma vez que o álcool anidro é isento de água e é usado na mistura com a gasolina, já o álcool hidratado é aquele usado diretamente no tanque dos automóveis e vendido diretamente ao consumidor nos postos de gasolina, sendo, exclusivamente, utilizado como combustível veicular, pertencente aos biocombustíveis da primeira geração; a ele é adicionada uma pequena quantidade de gasolina automotiva para conter tentativas de uso inadequado como, por exemplo, fabricação de bebidas - o álcool hidratado possui $96 \%$ de pureza e $4 \%$ de água $\left(96^{\circ} \mathrm{GL}\right)$. Em relação ao álcool anidro, esse pode ser misturado com a gasolina em diferentes proporções, resultando em um combustível com boas características antidetonantes.

Para cada $5 \%$ de álcool adicionado se consegue um aumento de octanagem em aproximadamente 2 pontos percentuais, sem os inconvenientes da adição dos compostos de chumbo, extremamente poluentes e que também destroem os elementos dos catalisadores. $\mathrm{O}$ álcool anidro possui características de pureza na ordem de 99,95\%, com 0,05\% de água na escala GL, ou seja, é considerado isento de água. O Brasil foi um dos primeiros países a banir o chumbo tetraetila da gasolina, passando a incorporar o álcool anidro como aditivo para aumentar a octanagem (SBRT, 2007).

Em se tratando do número de cetano $(\mathrm{NC})$ - nome comercial atribuído ao hidrocarboneto parafínico n-hexadecano - essa é uma característica que se relaciona, fisicamente, com o tempo de retardo de ignição de um combustível no momento em que ele sofre a compressão, em um motor do ciclo Diesel, de modo que, maior será o retardo dessa ignição quanto menor for o número de cetano, acarretando numa maior quantidade de combustível que permanecerá na câmara de compressão sem ter sido queimado no devido tempo. Tal fato ocasionará um mau funcionamento do motor, uma vez que quando a queima se der, irá liberar uma quantidade de energia superior àquela necessária e, por conseqüência, forçará em demasia o pistão e assim haverá possibilidade de ocorrerem danos mecânicos, além da perda de potência. Os combustíveis em cuja composição figuram altos teores de hidrocarbonetos parafínicos apresentam um elevado número de cetano, já os hidrocarbonetos aromáticos diminuem esse número e para a determinação dessa característica, o desempenho do óleo diesel dentro do motor é avaliado de acordo com o desempenho do n-hexadecano, de fórmula $\mathrm{CH}_{3}\left(\mathrm{CH}_{2}\right){ }_{14} \mathrm{CH}_{3}\left(\mathrm{C}_{16} \mathrm{H}_{34}\right)$, uma vez que o número de cetano está diretamente relacionado ao percentual volumétrico desse composto no combustível. Assim como no NO, 
foi arbitrado um valor para indicar a quantidade de n-hexadecano no combustível, sendo o máximo valor igual a 100 e o mínimo igual a zero, atribuído à presença do hidrocarboneto aromático $\alpha$-metil-naftaleno; posteriormente adotou-se o hepta-metil-nonano (HMN), de NC $=15$, tendo sido escolhido como limite inferior da escala por ser um produto mais estável. A determinação do número de cetano do combustível requer um motor padrão monocilíndrico especial conhecido (CFR) cuja razão de compressão é variável e apresenta instrumentação própria, sendo montado numa base estacionária, e se comporta de forma semelhante ao utilizado nos métodos MON e RON.

De forma semelhante ao número de cetano há um outro indicador muito utilizado conhecido como índice de cetano (IC), igualmente tido como medida-chave da qualidade de combustão dos combustíveis diesel, também está relacionado à qualidade da ignição - o período entre o começo da injeção de combustível e o início da combustão - sendo adotado por muitos setores da indústria petrolífera por estar correlacionado com o número de cetano e pode ser calculado partindo-se da densidade e temperatura de destilação de $50 \%$ do combustível conforme demonstrado pela equação (4.2) utilizada pela American Society for Testing Materials.

$$
\mathrm{IC}=454,74-1641,416 \mathrm{D}+774,74 \mathrm{D}^{2}-0,554 \mathrm{~B}+97,803(\operatorname{logB})^{2} \quad \text { Equação (4.2) }
$$

Com $\mathrm{D}=$ densidade a $15{ }^{\circ} \mathrm{C}\left(\mathrm{g} / \mathrm{cm}^{3}\right)$ e $\mathrm{B}=$ temperatura da destilação de $50 \%$ do produto $\left({ }^{\circ} \mathrm{C}\right)$

Geralmente, o NC apropriado para os motores diesel possui valores compreendidos na faixa de 40 e 60 e baixos valores do IC, normalmente abaixo de 40, que ocasionam dificuldades de partida a frio e acarretam um mau funcionamento dos motores, uma vez que proporcionam uma ignição fora do tempo, lenta, seguida por uma combustão muito rápida, levando a altos níveis de aumento de pressão, emissão de ruídos e poluentes (fumos) contratempos comumente associados aos motores do ciclo diesel; já altos valores do IC são responsáveis por uma rápida ignição seguida de uma combustão de boa qualidade do combustível, facilitando a partida a frio, reduzindo dessa forma as chances de desgaste dos pistões, a emissão de ruídos e poluentes como o monóxido de carbono, material particulado e hidrocarbonetos não queimados. É comum que um óleo diesel apresente, geralmente, um IC entre 40 e 60, podendo esse valor variar entre 50 e 60 para óleos leves e entre 30 e 45 para óleos pesados, sendo que a utilização de algumas substâncias que funcionam como aditivos, 
como o nitrato de amila, peróxido de acetila, dentre outros, possam elevar em até 13 pontos o IC desse combustível (informação online) ${ }^{3}$.

Tanto o NO quando o NC e o IC são importantes indicadores de qualidade relacionados às propriedades físico-químicas dos dois combustíveis, derivados de fontes fósseis, mais utilizados na atualidade, a gasolina e o óleo diesel. A compreensão dessas características possibilita divisões em termos de qualidade para esses combustíveis, acarretando em diferenças comerciais, tecnológicas e conseqüentemente, ambientais, uma vez que queimas mais eficientes de combustíveis, adequados ao projeto de seus motores, emitem menos poluentes atmosféricos, proporcionam maior geração de potência e acarretam em um consumo moderado de acordo com as especificações técnicas do veículo ou motor independente.

\subsection{Combustíveis fósseis}

O período histórico conhecido como Revolução Industrial (Reino Unido, meados do século XVIII) marcou, de forma clara, o que foi o início de um processo de transformações progressivas que continuam ocorrendo em diversas áreas da humanidade, sobretudo na sociedade, na tecnologia, na economia e no meio ambiente, conforme aponta Pereira (2002). O advento do tear a vapor, que marca o começo da Revolução Industrial, representa também o início de um aumento acelerado do consumo de combustíveis fósseis devido ao fato de que a era agrícola estava sendo superada e a máquina suplantando o trabalho humano. O carvão mineral se tornava então o principal combustível das novas máquinas a vapor, cuja utilização cresceria de forma vertiginosa ao longo do século XIX, graças também a fatores combinados como o liberalismo econômico, a acumulação de capital e uma diversidade de invenções como o motor a vapor (também chamado de máquina a vapor ou turbina a vapor). Mais tarde a utilização do querosene, conhecido derivado do petróleo, como fonte energética para iluminação, em substituição ao óleo de baleia, através da sua combustão em lampiões, originaria uma ampliação do uso de derivados de petróleo e do gás natural em motores de combustão.

\footnotetext{
${ }^{3}$ Material extraído do website da empresa britânica Beyond Petroleum (antiga British Petroleum) disponível em $<$ http:www.bp.com>. Acesso em 24 de outubro de 2008.
} 
As finalidades foram se diversificando à medida que o processo de industrialização seguia seu curso e isso explicaria a explosão no consumo de combustíveis fósseis desencadeada pela Revolução Industrial. Os combustíveis fósseis, também conhecidos como combustíveis minerais, foram formados pela decomposição anaeróbica de matéria orgânica, em conjunto com a pressão e a temperatura, através de um processo que leva milhares e milhares de anos e, por este motivo, não são renováveis ao longo da escala de tempo humana, ainda que ao longo de uma escala de tempo geológica esses combustíveis continuem a ser formados pela natureza - isto segundo a teoria mais aceita na atualidade, a biogênica. Segundo Major (1996) o processo padrão para formação do carvão começa, comumente, em um ambiente pantanoso; normalmente saturados de água, os musgos, as folhas, galhos e outras partes das árvores não se decompõem completamente nesse local que exala podridão e com o passar dos anos o pântano pode ser coberto por areia e lama quando inundações provenientes de rios ocorrem ou quando há um aumento nos níveis oceânicos. Sob o peso destes sedimentos, essa camada conhecida como turfa, pode perder parte de sua água e gases, acabando por se transformar em um tipo leve de carvão chamado linhita, de coloração marrom e aspecto lenhoso. Com a crescente ação da pressão e temperatura, mais água e gases são conduzidos para fora, formando a conhecida família dos carvões betuminosos e, finalmente, altas temperaturas e pressão podem causar tais carvões a se transformarem em uma variedade dura e preta, chamada antracitro. A profundidade de formação é mais relevante do que a temperatura em se tratando das variedades do carvão.

De acordo com Brownlow apud Major (1996) em se tratando do petróleo a ciência não tem uma teoria relativamente simples como a do "modelo pântano" para formação do carvão. Em verdade muito ainda pode ser debatido se o petróleo tem uma origem biológica ou nãobiológica, contudo a maioria dos pesquisadores que o estuda acredita que ele é derivado, afinal, de organismos vivos e parte do problema em explicar a origem do petróleo é a sua diversidade. O petróleo é encontrado em diversas situações geológicas e sua química varia de um lugar para outro, no entanto, há um fator comum: o óleo sempre é encontrado em rochas sedimentares de origem marinha e por esta razão acredita-se que o petróleo é proveniente dos restos de inúmeras plantas e animais marinhos, mortos há eras atrás, que ficaram depositados no leito de mares e oceanos que não mais existem (informação de aula) ${ }^{4}$.

\footnotetext{
${ }^{4}$ Material extraído da disciplina Introdução ao Petróleo e Gás Natural do Programa Interunidades de PósGraduação em Energia (PIPGE) do Instituto de Eletrotécnica e Energia (IEE) da Universidade de São Paulo (USP), 2007.
} 
Essa matéria orgânica, então soterrada por muitos metros de sedimentos, foi convertida pela pressão, calor e várias reações bioquímicas, se transformando em diversos tipos de hidrocarbonetos coletivamente conhecidos como o óleo bruto ou petróleo. Com o constante aumento de sedimentos e calor houve uma separação entre os hidrocarbonetos de maior peso molecular, e os de menor peso, como o metano $\left(\mathrm{CH}_{4}\right)$, dando origem ao que se conhece como gás natural. Um importante conceito no que tange as variedades do óleo bruto encontrado na natureza diz respeito à sua densidade, de forma tal que sua classificação é dependente dessa propriedade, tendo sido classificado em leve, médio, pesado e ultra pesado. Essa propriedade, por si só, é de extrema relevância pois já reflete a composição daquele petróleo e o American Petroleum Institute determinou uma medida que passou a ser utilizada por toda a indústria petrolífera: o ${ }^{\circ} \mathrm{API}$ que expressa a densidade do óleo medida em relação à água com o propósito maior de identificar rapidamente qual a qualidade do óleo bruto a ser tratado, sendo expresso pela equação (4.3) e medido dentro das chamadas condições padrão (standard-std) de $25^{\circ} \mathrm{C}\left(68^{\circ} \mathrm{F}\right)$ e 1 atm. Quanto maior for o valor do ${ }^{\circ} \mathrm{API}$ de um dado petróleo explorado, mais leve ele será, aumentando dessa forma o interesse por ele e fazendo com que seu valor cresça, conseqüentemente, quando negociado.

${ }^{\circ} A P I=\frac{141,5}{\rho}-131,5$

Equação (4.3)

A densidade específica do óleo é expressa por $\rho$ e calculada pela razão entre a densidade do óleo em questão e a densidade da água. Segundo essa classificação é possível dividir os tipos de petróleo em:

(a) Base parafínica (óleo pesado) formado majoritariamente por alcanos e produz gasolina de baixa octanagem;

(b) Base aromática (óleo médio) tendo em sua composição de 25 a 30\% de hidrocarbonetos aromáticos; e

(c) Base naftênica (óleo leve) possuindo cerca de 15 a 25\% de ciclo-alcanos e produz gasolina de alta octanagem dentre outros produtos de boa qualidade.

$\mathrm{Na}$ tabela (4.2) é possível verificar os valores assumidos por algumas instituições/setores da indústria petrolífera como a canadense Alberta Government, a OPEP e 
ANP, no que diz respeito à classificação dos óleos quanto ao valor do seu ${ }^{\circ} \mathrm{API}$, sendo possível notar pequenas diferenças nos valores calculados.

\section{Tabela 4.2 Diferentes valores sugeridos para $0^{\circ} \mathrm{API}$}

\begin{tabular}{|c|c|c|c|c|}
\hline \multirow{2}{*}{ Indístria Petrolifera } & \multicolumn{4}{|c|}{${ }^{\circ} A \mathrm{PI}(\mathrm{gra} 11 \mathrm{~s} A \mathrm{FT})$} \\
\hline & Oleo Leve & Oleo Médio & Oleo Pesado & Ultrapesado \\
\hline Albetta Govertuthent & $\geq 34$ & $25-34$ & $10-25$ & $\leq 10$ \\
\hline U.S. Departruent of Energy & $\geq 35,1$ & $25-35,1$ & $10-25$ & $\leq 10$ \\
\hline OFEF & $\geq 32$ & $26-32$ & $10,5-26$ & $\leq 10,5$ \\
\hline Petrobras (Offshore) & $\geq 32$ & $19-32$ & $14-19$ & $\leq 14$ \\
\hline Petrobtas (Otishote) & $\geq 32$ & $18-32$ & $13-18$ & $\leq 13$ \\
\hline AVF & $\geq 31,1$ & $22,3-31,1$ & $12-22,3$ & $\leq 12$ \\
\hline
\end{tabular}

Fonte: (Adaptado de TN Petróleo nº 57, p. 77)

Essa e outras propriedades associadas ao petróleo como, por exemplo, suas condições de extração e logística - cadeias upstream e downstream - impactam diretamente no mercado internacional de combustíveis, uma vez que a formulação de preços para o petróleo tem como referência (benchmarking) os petróleos de qualidade superior, como é o caso do West Texas Intermediate (WTI) que é o petróleo natural da região de West Texas, EUA, e concentra a maior produção da América do Norte; é um petróleo que possui entre 38 e $40^{\circ} \mathrm{API}$, teor de enxofre de $0,30 \%$ e serve de referência para os mercados de derivados petroquímicos no EUA. Há o petróleo do tipo Brent, produzido no Mar do Norte, na Europa, servindo de referência para o mercado de derivados da Europa e da Ásia; é uma mistura de petróleos (blend) que possui 39,4 ${ }^{\circ}$ API e teor de enxofre de 0,34\%. Ainda pode-se mencionar o petróleo vindo de Dubai, nos Emirados Árabes Unidos, que possui $31^{\circ} \mathrm{API}$ e teor de enxofre de $2,00 \%$, sendo o principal petróleo de referência para precificação dos óleos vindos do Golfo Pérsico e exportados pra Ásia (informação online) ${ }^{5}$.

O carvão mineral, os derivados do petróleo (gasolina, óleo diesel, entre outros) e ainda o gás natural são os combustíveis fósseis mais conhecidos e utilizados na atualidade. O aumento do controle e do uso, por parte do homem, da energia contida nesses combustíveis fósseis, mais abundantes e baratos no passado, foi determinante para algumas das transformações econômicas, sociais, tecnológicas - e infelizmente ambientais - que vêm ocorrendo desde então na história da civilização. Dentre as conseqüências ambientais do processo de industrialização e do inerente e progressivo consumo de combustíveis fósseis entenda-se energia - destaca-se o aumento da contaminação do ar por gases e material 
particulado, provenientes justamente da queima destes combustíveis, gerando uma série de impactos locais sobre a saúde humana, dentre eles os perigosos efeitos causados pelo smog fotoquímico que se caracteriza como um fenômeno climático decorrente de reações químicas que ocorrem na troposfera, cujo ozônio $\left(\mathrm{O}_{3}\right)$ é um dos componentes, como indicado no artigo “Ozone" da EPA (2003).

A denominação smog (fusão entre as palavras de origem inglesa smoke e fog) se refere a uma condição de instabilidade atmosférica que provoca reduzida visibilidade e ampla concentração de gases poluentes e material particulado. Esse fenômeno é intenso em grandes centros urbanos, sendo responsável por danos à saúde humana, em especial às pessoas que possuem doenças ou disfunções respiratórias (informação de aula) ${ }^{6}$. Outro contratempo ambiental é a mudança global do clima, um assunto cada vez mais presente nas pautas das empresas e entidades governamentais do mundo inteiro; este, porém, é bastante complexo e traz conseqüências possivelmente catastróficas por ser um problema que vem sendo causado pela intensificação do efeito estufa que, por sua vez, está relacionado ao aumento da concentração, na atmosfera da Terra, de gases que possuem características específicas.

Conforme consta na obra The Greenhouse Effect and Climate Change cabe lembrar que o efeito estufa existe na Terra independentemente da ação do homem. Ela é cercada por uma camada de ar, segura pela gravidade do planeta, e formada quase que por $78 \%$ de nitrogênio $\left(\mathrm{N}_{2}\right)$ e $21 \%$ de oxigênio $\left(\mathrm{O}_{2}\right)$. Esses componentes são essencialmente transparentes para a radiação solar (ondas curtas) e para a radiação infravermelha (ondas longas) emitidas pela reflexão provocada pela superfície terrestre.

Gases como o dióxido de carbono e o vapor d'água permitem a entrada da luz solar, mas impedem que parte do calor no qual a luz se transforma volte para o espaço pois são altamente absorventes - isso se dá devido à mudança do comprimento de onda da radiação infravermelha ao ser refletida. A radiação ao ser absorvida por esses gases é emitida novamente em todas as direções e algumas estão direcionadas novamente para a superfície terrestre.

\footnotetext{
${ }^{5}$ Material publicado pelo departamento de Engenharia do Petróleo (Engenharia Mecânica) da Universidade de Campinas (UNICAMP) em seu website: <http://www.dep.fem.unicamp.br/>. Acesso em 22 de outubro de 2008.

${ }^{6}$ Material extraído da disciplina Tópicos de Química Ambiental II do curso de graduação em Engenharia Ambiental da Escola Politécnica (EP) da Universidade de São Paulo (USP), 2007.
} 
Este processo de aprisionamento do calor é análogo ao que ocorre em uma estufa - daí o nome atribuído a esse fenômeno e também aos gases que possuem essa propriedade de aprisionamento parcial de calor, chamados de gases de efeito estufa (GEE), dentre os quais, além dos supracitados, existe o metano que possui um poderoso efeito sobre o aquecimento global. O dióxido de carbono, assim como o vapor d'água, por exemplo, não causam nenhum dano à saúde e não poluem o meio ambiente, sendo incorreto classificá-los dessa forma. É coerente mencionar que este fenômeno não deve ser interpretado como um problema climático já que sem o efeito estufa o sol não conseguiria aquecer a Terra o suficiente para que ela fosse habitável como se conhece hoje e a temperatura média do planeta estaria em torno de $18^{\circ} \mathrm{C}$ negativos $(255 \mathrm{~K})$, cerca de $32{ }^{\circ} \mathrm{C}$ inferior à temperatura média atual, portanto o problema não é o efeito estufa, mas sim sua intensificação. Segundo muitas pesquisas realizadas nos últimos anos é importante atentar para o fato de que o aumento das emissões e da concentração atmosférica de dióxido de carbono $\left(\mathrm{CO}_{2}\right)$ pode estar relacionado com o aumento da utilização dos combustíveis de origem fóssil. Por sua vez, o aumento da concentração desse gás e de outros GEE é o responsável pela intensificação do efeito estufa e pelo aumento do calor retido na atmosfera (energia térmica), tendo influência no comportamento climático do planeta, uma vez que toda essa energia térmica é a responsável pela evaporação e precipitação das águas e circulação dos ventos e das correntes marítimas.

Outros gases causam impactos em regiões diferentes dos pontos a partir dos quais são emitidos, como é o caso do dióxido de enxofre $\left(\mathrm{SO}_{2}\right)$ e dos óxidos de nitrogênio $\left(\mathrm{NO}_{\mathrm{x}}\right)$. Usinas e grandes fábricas queimam carvão e petróleo para a produção de energia elétrica; carvão e gás natural também são queimados para o aquecimento doméstico assim como carros, caminhões, aviões e muitos outros veículos utilizam combustíveis derivados de fontes fósseis. A fumaça proveniente da queima de tais combustíveis contém os compostos supracitados e ela se eleva e se mistura com o ar da atmosfera encontrando a umidade e gerando o fenômeno da chuva ácida. Segundo Hedin e Likens (1996), mesmo com as constantes medidas ambientais para mitigar os efeitos danosos da chuva ácida, essa anomalia atmosférica continua a ter espaço na Europa e na América do Norte. Através da utilização dos combustíveis fósseis a condição climática do planeta tem sofrido interferência antropogênica, isto é o que afirma de forma categórica o Painel Intergovernamental sobre Mudança Climática, ou simplesmente IPCC (Intergovernamental Panel on Climate Change), formado por inúmeros cientistas do mundo, inclusive do Brasil. A interação antropogênica sobre o clima do planeta tem provocado um aumento da temperatura média na atmosfera ocasionando, dessa forma, a elevação do nível dos oceanos, o derretimento das geleiras e das 
calotas polares, perda de biodiversidade, mudanças no regime de chuvas, intensificação de fenômenos extremos (tais como secas, inundações, furacões e tempestades tropicais), desertificação, perda de áreas agriculturáveis, aumento da incidência de doenças transmissíveis por mosquitos e outros vetores (malária, febre amarela e dengue, por exemplo), acirramento dos problemas relacionados ao abastecimento de água doce, aumento de fluxos migratórios, entre outros (CONEJERO, 2006). Todos esses fenômenos atribuídos às mudanças climáticas podem colocar em questão os padrões de produção e consumo da atualidade já que suas causas estão ligadas, de alguma forma, ao consumo de combustíveis fósseis - principal fonte primária da energia e força motriz da economia global. Muitos estudos mencionam a possibilidade de descarbonizar a matriz energética mundial, isto é, aumentar a participação das energias renováveis em detrimento dos combustíveis fósseis, como é mencionado na matéria "O que fazer com o carvão?" (SCIENTIFIC AMERICAN, 2006). Esta seria uma condição necessária mas não suficiente para a atenuação da mudança do clima que depende também de outras mudanças na infra-estrutura, na tecnologia e na economia pois, adiar a captura e o armazenamento de carbono nas usinas termelétricas a carvão, por exemplo, poderia ser visto como algum tipo de falta de visão.

A energia oriunda das fontes fósseis caracteriza-se por ser a principal força motriz do sistema econômico global e responsável por também influenciar o tipo e a quantidade de uma enorme gama de bens produzidos na economia mundial; ocorre que uma diminuição no que tange o uso de combustíveis fósseis poderá depender de mudanças significativas como a inclusão de novas tecnologias e realocações econômicas em setores como o industrial e o de transportes. Esta diminuição exigirá, por exemplo, que determinadas empresas - como empresas de geração de energia termelétrica a carvão - realizem mudanças em seus negócios ou lidem com perdas significativas de mercado. Isto poderá gerar uma forte resistência por parte de algumas dessas empresas, muitas das quais possuem considerável peso econômico e político no cenário comercial e político internacional. De acordo com Goldemberg et al. (1988) o petróleo é uma mercadoria relativamente escassa, de grande valor na atualidade, cujo suprimento é dominado por uns poucos produtores para o qual não há substitutos imediatos em muitos de seus principais usos - embora muitas tecnologias se proponham a apresentar caminhos alternativos para uma grande diversidade de produtos da indústria petroquímica, ainda sim, devido às implicações técnicas e comerciais, tais tecnologias ainda são vistas como um suporte. O petróleo, acima de tudo, simplesmente não é o candidato mais adequado para atender o aumento substancial da demanda de energia nos países emergentes e o mesmo pode ser dito do carvão, mesmo levando em consideração que suas reservas são muito mais 
abundantes que as de petróleo no mundo - embora, exceto pela China, a maioria dos países tenha apenas modestas fontes de carvão - cabe ressaltar que as fontes fósseis, atualmente, representam a maior fatia de energia primária consumida no mundo, seja na forma de combustíveis veiculares, como gasolina e óleo diesel, ou seja na forma da gigantesca gama de bens derivados da indústria petroquímica.

\subsubsection{Gasolina}

A gasolina é um combustível primordialmente derivado do petróleo e possui larga utilização no mundo moderno, principalmente em motores de combustão interna de veículos automotivos e aeronaves. Originalmente, a gasolina era um subproduto indesejado da indústria de refinamento de petróleo, que estava interessada, principalmente, na obtenção do querosene e pode-se dizer que as refinarias desprezavam toda a gasolina obtida. Com o advento dos motores de combustão interna, ela passou a ser considerada a melhor opção para combustível devido a algumas de suas características como alta energia de combustão, alta volatilidade e sua compressibilidade. Para sua produção são utilizados inúmeros processos de refino compreendendo várias etapas; de uma forma geral, partindo-se do petróleo, o processo tem início com uma simples separação física, conhecida como destilação e a partir da destilação se aproveita um componente chamado nafta - importante produto da indústria petroquímica - para a produção da gasolina. Dessa mesma destilação são obtidas outras parcelas, sendo uma delas denominada gasóleo - fração dos hidrocarbonetos que tem a mesma faixa de destilação do óleo diesel, sendo ele um produto intermediário que serve de matéria-prima para a produção de GLP e gasolina na unidade de craqueamento. Esse gasóleo passa por um complexo processo de modificação estrutural a nível molecular chamado craqueamento catalítico. Deste processo é obtida outra substância, chamada nafta de craqueamento, que pode ser adicionada à nafta de destilação, anteriormente obtida, para a produção de gasolina.

Uma mistura bastante complexa é como se pode definir a gasolina, pois pode conter centenas de diferentes hidrocarbonetos sendo a maioria hidrocarbonetos saturados que contém de 5 a 12 átomos de carbono por molécula. Conforme Campos e Leontsinis (1990), os hidrocarbonetos componentes da gasolina são membros das séries parafínica, naftênica e aromática, e suas proporções relativas dependem dos petróleos e processos de produção 
utilizados. É comumente isenta de partículas em suspensão, incolor, amarelada ou levemente alaranjada (pode assumir outras cores de acordo com o aditivo empregado); volátil e inflamável, evaporando rapidamente quando em contato com o ar e consiste em uma mistura líquida, à temperatura e pressão ambiente, de hidrocarbonetos e apresenta também pequenas quantidades de alcanos cíclicos, compostos aromáticos, oxigenados (quando adicionada de álcool etílico anidro, por exemplo), de enxofre, nitrogênio e componentes metálicos (informação de aula) ${ }^{7}$.

Segundo Côcco, Yamamoto e von Meien (2004) mais de 500 componentes diferentes podem ser encontrados em uma simples amostra de gasolina e, ainda sim, apresentar um pequeno percentual de componentes não identificados, que podem ser, usualmente, constituídos de enxofre, nitrogênio e até mesmo algumas olefinas e compostos aromáticos de difícil classificação. Sua composição também irá depender de sua utilização - seja para aviação, seja automotiva - e dependerá também da composição do petróleo e dos processos de obtenção que foram utilizados. A princípio a gasolina era obtida pela destilação fracionada do petróleo - era simplesmente a fração líquida mais volátil do óleo bruto porém, com o passar do tempo, e com o avanço tecnológico, outras técnicas surgiram numa tentativa de aumentar o rendimento desta extração, sendo uma delas o craqueamento térmico (cracking) que consiste numa quebra de moléculas grandes em outras menores que pertencem à fração da gasolina. $\mathrm{O}$ craqueamento térmico foi utilizado por algum tempo até o dia no qual químicos de catálise desenvolveram o processo chamado de craqueamento catalítico, que consiste num método mais econômico e eficaz que emprega catalisadores para facilitar as reações químicas e produzir mais gasolina.

Atualmente muitos processos são conhecidos e utilizados para obtenção da gasolina a partir do petróleo. Os tradicionais processos de refino sofreram uma contínua evolução ao mesmo tempo em que os motores automotivos progrediam e conforme esses sofriam modificações, principalmente com relação a sua taxa de compressão ao objetivar uma maior potência, os processos de refino eram aperfeiçoados para a fabricação de gasolina a fim de satisfazer os requisitos de qualidade da mesma, que se tornavam cada vez mais exigentes por exemplo a octanagem, ou iso-octanas, que caracteriza-se por ser uma exigência para o bom funcionamento dos motores do ciclo Otto.

\footnotetext{
${ }^{7}$ Material extraído do Virtual Chembook do professor Charles E. Orphardt (2003) do Elmhurst College, no estado norte-americano de Ilinois (IL). Disponível em $<$ http://www.elmhurst.edu/ chm/vchembook/514 gasoline.html> Acesso em 26 fev. 2008.
} 
O consumo de gasolina gerou novas pesquisas e ocasionou um desenvolvimento dos processos de refino, viabilizando melhores rendimentos que guiaram a atual da indústria de refino do petróleo. Conforme é apontado por Cruz (2003) os processo de obtenção da gasolina são variados, cada um possui muitas particularidades e pode-se mencionar a reforma, que pode ser térmica - já em desuso - ou catalítica, que é um processo onde é possível combinar hidrocarbonetos menores para se obter outros de maior peso molecular e assim converter frações de hidrocarbonetos de baixa octanagem da faixa da gasolina em frações de octanagem elevada; a alquilação, que consiste num processo cujo propósito é a reunião de duas moléculas, usualmente uma olefina e uma iso-parafina, a fim de originar uma terceira, de peso molecular mais elevado e mais ramificada; a polimerização que, de forma semelhante à alquilação, é um processo para fazer gasolina a partir de gases de refinaria porém somente reagem os gases olefínicos, ligando suas moléculas para formar líquidos olefínicos; e por fim a isomerização que converte hidrocarbonetos de cadeia linear em seus isômeros de cadeia ramificada fazendo com que o composto sofra uma reestruturação sem alterar seu peso molecular e assim, por exemplo, o heptano normal (n-heptano) que tem índice de octano zero (um dos padrões na escala de índice de octano) pode ser isomerizado dando uma mistura de iso-heptanos, alguns dos quais possuem NO superior a 100; entretanto a destilação fracionada e o craqueamento são os mais importantes e merecem um destaque maior.

\subsubsection{Destilação fracionada}

A palavra "destilação" é originária do latim distillare, que significa "gotejar", e descreve o estágio final do processo, quando o gotejamento de um líquido de um condensador é coletado por um recipiente adequado. Conforme Ferreira e Aquino Neto (2005) na indústria petrolífera esse processo de separação é o mais utilizado sendo de suma importância o conhecimento dos valores na distribuição dos pontos de ebulição dos produtos derivados do petróleo; no processo de refino é essencial esse domínio para garantir a qualidade do mesmo. Os primeiros procedimentos de destilação, padronizados pela American Society for Testing and Materials (ASTM), datam de 1926. O petróleo é submetido a temperaturas que variam de $350{ }^{\circ} \mathrm{C}$ a $400{ }^{\circ} \mathrm{C}$ sendo, em seguida, direcionado para uma torre de fracionamento onde, à pressão atmosférica, é separado em diferentes frações segundo o ponto de ebulição de cada uma; algumas dessas frações são a gasolina de destilação primária, a nafta, o querosene, o 
óleo diesel, dentre outras. Segundo Dunhan et al. (2003), de uma perspectiva técnicacientífica, o princípio da trajetória tecnológica do refino do petróleo é o uso dos conhecimentos de termodinâmica em sistemas líquido-vapor para a separação física das moléculas de hidrocarbonetos em diferentes faixas de peso molecular; essa separação é possível uma vez que a temperatura de ebulição e o peso molecular estão relacionados, e tanto a quantidade como a composição de hidrocarbonetos da gasolina primária dependem do tipo do petróleo que foi destilado, variando suas propriedades, como por exemplo a densidade, características de vaporização, poder antidetonante, dentre outras.

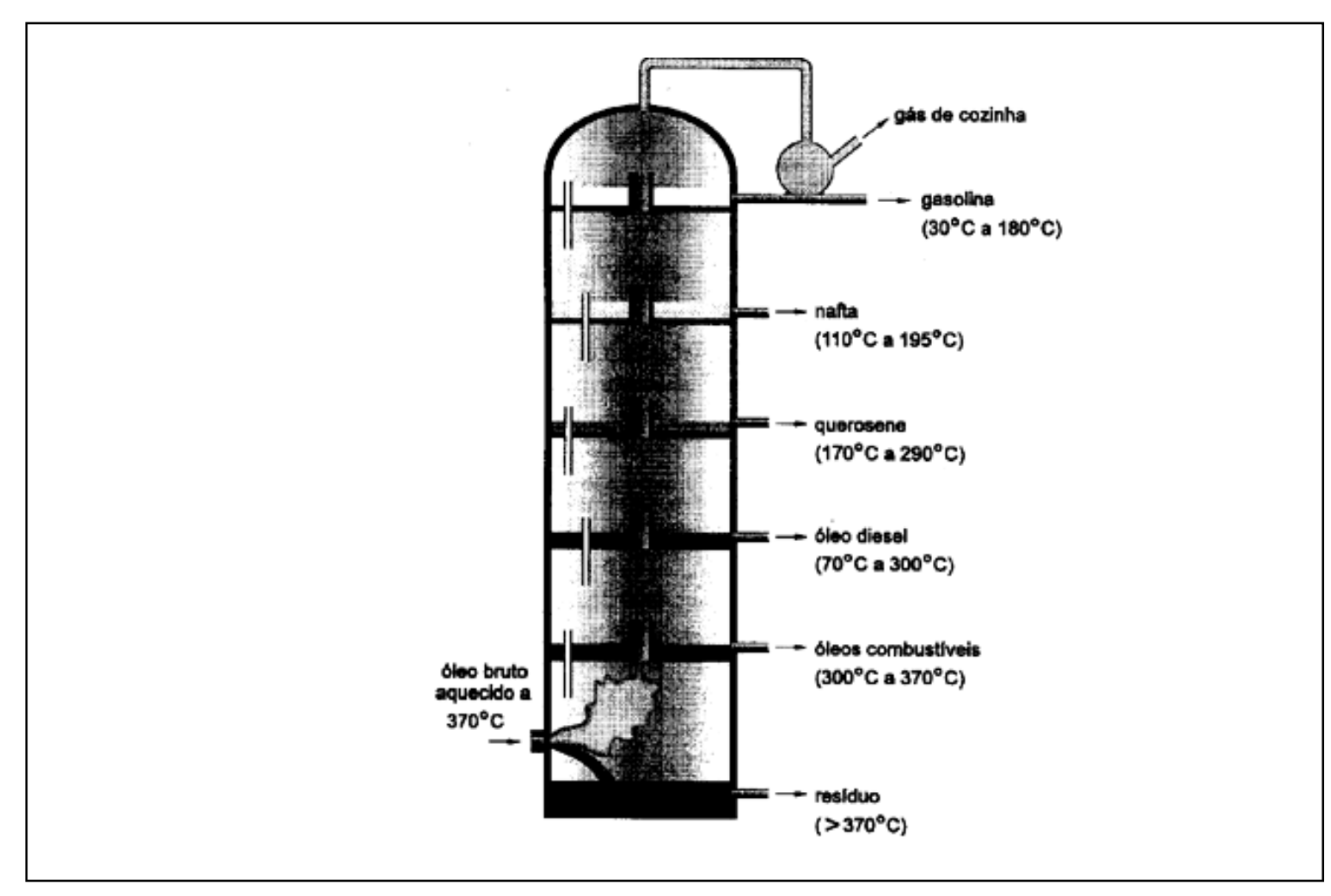

Figura 4.2 Torre de destilação fracionada esquemática

Fonte: (informação online) ${ }^{8}$

A gasolina é a fração do petróleo que destila entre $30{ }^{\circ} \mathrm{C}$ e $180{ }^{\circ} \mathrm{C}$ conforme indicado na figura (4.2) onde é apresentada uma torre de destilação fracionada esquemática e pode-se observar alguns dos produtos obtidos do processo e seus respectivos pontos e ebulição - notar que a gasolina é a fração líquida mais leve do óleo bruto recebendo o nome de gasolina natural.

\footnotetext{
${ }^{8}$ Material disponibilizado pelo professor de química Gilton Lyra no website Educação 360. Disponível em $<$ http://pe360graus.globo.com/educacao360/colunaLerX.asp?columnId=\&articleId=667> Acesso em 26 mar. 2008.
} 
Isso ocorre uma vez que o gás proveniente dos poços petrolíferos, conhecido como gás natural, consiste numa mistura de hidrocarbonetos leves, sendo predominante o metano $\left(\mathrm{CH}_{4}\right)$, que acaba por arrastar certa quantidade de hidrocarbonetos da faixa da gasolina (os mais voláteis). Estes hidrocarbonetos constituem o que se conhece como gasolina natural, possível de ser recuperada pelo processo field condensate (recuperação na boca do poço) . Ela consiste em uma mistura de hidrocarbonetos que se encontra na fase líquida, em determinadas condições de pressão e temperatura, normalmente obtida do processamento do gás natural rico em hidrocarbonetos pesados. É composta essencialmente de pentano $\left(\mathrm{C}_{5} \mathrm{H}_{12}\right)$ e outros hidrocarbonetos de peso superior porém em menor quantidade. A grande quantidade de hidrocarbonetos parafínicos de cadeia linear existentes na gasolina natural acaba comprometendo seu IAD (Índice Anti-Detonante) e, por este motivo, acaba por limitar sua quantidade na mistura que compõe a gasolina final.

\subsubsection{Craqueamento (cracking)}

Trata-se de uma transformação por ruptura. O craqueamento consiste em provocar a “quebra" ou "divisão" das grandes moléculas de hidrocarbonetos - que possuem, por sua vez, alto ponto de ebulição - onde um composto é dividido em partes menores pela ação de calor e/ou catalisador, para produzir outro de menor ponto de ebulição na faixa desejada, nesse caso, na faixa da gasolina. A "quebra" do gasóleo em gasolina (iso-octano) e o gás liquefeito de petróleo (GLP), que consiste numa mistura de propano $\left(\mathrm{C}_{3} \mathrm{H}_{8}\right)$ e butano $\left(\mathrm{C}_{4} \mathrm{H}_{10}\right)$, pode ser ilustrada pela equação (4.4), demonstrando assim o processo de craqueamento.

$\mathrm{C}_{36} \mathrm{H}_{74}$ (gasóleo parafínico) $\rightarrow \mathrm{C}_{8} \mathrm{H}_{18}$ (iso-octano) $+\mathrm{C}_{3} \mathrm{H}_{8}+\mathrm{C}_{4} \mathrm{H}_{10} \quad$ Equação (4.4)

Pode-se utilizar o chamado processo de craqueamento térmico ou então craqueamento catalítico, sendo que o primeiro, já em desuso, faz com que grandes cadeias de hidrocarbonetos sejam aquecidas a altas temperaturas (e algumas vezes a altas pressões também) até que elas se "quebrem; há o craqueamento térmico a vapor, por viscorredução e também por coqueamento. O craqueamento catalítico, usado atualmente, permite o uso de pressões mais baixas do que o craqueamento térmico pois usa um catalisador para aumentar a velocidade da reação de craqueamento e esses catalisadores incluem a zeólita, hidrossilicato 
de alumínio, bauxita e alumino-silicatos. Há o FCC (craqueamento catalítico fluido) onde um catalisador fluido aquecido a $538^{\circ} \mathrm{C}$ craqueia o gasóleo pesado em óleo diesel e gasolina; e há o chamado hidrocraqueamento catalítico (HCC), utilizando hidrogênio $\left(\mathrm{H}_{2}\right)$ e que consiste, assim como no craqueamento, em quebrar as frações pesadas do petróleo, em presença de hidrogênio e de um catalisador, em gasolina ou outros produtos destilados de tamanho intermediário (querosene e óleo diesel) assegurando também a eliminação de heteroátomos (como nitrogênio e enxofre), permitindo a produção de combustíveis de melhor qualidade. A gasolina proveniente do processo conhecido como craqueamento catalítico caracteriza-se por ser um excelente componente para mistura final ( $p o o l$ ), pois possui elevado NO e quanto aos hidrocarbonetos parafinicos e naftênicos, de octanagem menor, são convertidos, em sua maioria, em olefinas e hidrocarboneto aromáticos de alto NO. As gasolinas de craqueamento catalítico possuem NO na ordem de 92 a 94, antes da mistura com aditivos antidetonantes.

\subsubsection{Variedades da gasolina}

Conforme especificado por Neiva (1993) a gasolina automotiva é composta de hidrocarbonetos que contém de 5 a 12 átomos de carbono, com pontos de ebulição que variam de $30{ }^{\circ} \mathrm{C}$ a $225^{\circ} \mathrm{C}$, podendo conter variados aditivos a fim de conferir algumas características específicas, em sua maioria, reguladas por normas de uma determinada região ou país na qual é comercializada. Os hidrocarbonetos que compõe a gasolina podem ser parafínicos, olefínicos, naftênicos e/ou aromáticos, em diferentes proporções relativas que dependem da origem do petróleo utilizado e de qual processo de produção foi adotado; na atualidade a mistura que compõe a gasolina final (pool) é fruto de inúmeros processos de refino, constituindo uma criteriosa mistura desses hidrocarbonetos a fim de torná-la balanceada para atender aos requisitos de desempenho de diferentes motores. Baseadas em seu número de octanas (NO), de acordo com a ANP, as gasolinas automotivas comercializadas no Brasil são classificadas, comumente, em quatro tipos: gasolina comum, gasolina supra (comum aditivada), gasolina premium e gasolina podium sendo que todas recebem, por força de lei federal $\mathrm{N}^{\mathrm{o}} 10.696 / 2003$, a adição de álcool etílico anidro cujo teor pode variar de $20 \%$ a $25 \%$, em volume, sendo que o percentual de AEAC (álcool etílico anidro combustível) adicionado à gasolina, a partir do ano de 2004, foi de 20\% até novembro de 2006; de 23\% até junho de 2007; e finalmente de $25 \%$ a partir de julho de 2007. 
No Brasil, o Departamento Nacional de Combustíveis (DNC) especifica três classificações básicas para as gasolinas automotivas: tipo "A", tipo "B" e tipo "C", sendo a segunda, do tipo "B", de uso exclusivo das forças armadas; essas gasolinas são subdividas em gasolina comum e aditivada; gasolina tipo "A" é produzida pelas refinarias de petróleo e entregue diretamente às distribuidoras, consistindo em uma mistura de naftas numa proporção tal que enquadre o produto nas especificações estabelecidas pela ANP, já a gasolina tipo "C" é uma gasolina tipo "A" proveniente das distribuidoras que, por sua vez, a receberam das refinarias, contudo adicionada de AEAC, sendo essa gasolina a que se encontra disponível no mercado, comercializada nos postos revendedores. Uma variedade comercial da gasolina é a conhecida gasolina tipo premium, cuja produção requer modernos processos para fornecerem um produto de elevada octanagem sendo que o tempo para sua produção irá variar de acordo com o tipo de petróleo utilizado e quais os processos tecnológicos adotados. Além do NO diversos aspectos devem ser considerados para a produção de uma gasolina de boa qualidade como, por exemplo, seu teor de enxofre, sua volatilidade, capacidade corrosiva, dentre outros, de forma a garantir um funcionamento adequado nos motores do ciclo Otto. A gasolina do tipo premium pode ser utilizada em qualquer veículo normalmente movido a gasolina, em especial àqueles equipados com a tecnologia da injeção eletrônica, sendo altamente indicada para veículos que funcionem com motores de alto desempenho e/ou que requeiram combustíveis de elevado NO; na atualidade, essa gasolina é comercializada, em sua maioria, na Bahia e em Pernambuco, em um número reduzido de postos, dado o fato de que foi largamente substituída pela gasolina podium (informação online) ${ }^{9}$.

Já a gasolina Podium foi lançada em junho de 2002 e reúne algumas características únicas no mercado brasileiro e para efeitos legislativos é classificada pela ANP como sendo uma gasolina do tipo premium, cujo IAD é de 95, com uma composição distinta dada a presença de aditivos que reduzem o acúmulo de resíduos no motor. Foi considerada um conceito inovador em termos de combustível e aprovada pela Equipe Williams da Fórmula 1, tendo utilizado parte da concepção da gasolina utilizada na Fórmula 1. Entretanto, a gasolina efetivamente utilizada em corridas da F1 é especialmente desenvolvida para competição, não sendo a mesma gasolina comercializada nos postos.

\footnotetext{
9 Material extraído do website da empresa Petrobras - Petróleo Brasileiro S/A. <http://www2.petrobras.com. br/portugues/index.asp> Acesso em 01 abr. 2008.
} 
Uma importante diferença que faz essa gasolina figurar entre as melhores do mundo, além da presença de detergentes automotivos e menor emissão de poluentes, está em seu alto NO dada a adição obrigatória, em território brasileiro, de AEAC, proporcionando-lhe uma coloração alaranjada já que, em outros países do mundo como é o caso dos EUA, essa adição não é compulsória. Existem outros tipos de gasolinas aditivadas e de boa qualidade sendo comercializadas no país, como é o caso, por exemplo, da gasolina V-Power da Shell, formulada para reduzir o atrito entre as peças móveis do motor, fazendo com que a energia despendida sob a forma de atrito seja mais bem aproveitada, convertendo-se em ganho no tempo de resposta em aceleração do motor. A gasolina V-Power garante menor desgaste das peças do motor, maior limpeza e um melhor funcionamento do motor por também conter, dentre esses, aditivos detergentes semelhantes aos das outras gasolinas aditivadas (informação online) ${ }^{10}$.

Tem-se ainda uma mistura combustível conhecida como MEG, composta de metanol, etanol e gasolina, de coloração rósea, já tendo sido utilizada em momentos onde houve falta de AEAC nos postos fornecedores; e há também a gasolina de aviação que caracteriza-se por apresentar um alto índice de desempenho cujo NO pode variar de 110 a 130, sendo constituída por hidrocarbonetos saturados e obtida através de processos desenvolvidos especialmente para a produção de compostos com um elevado índice de octanas, por exemplo, reforma, isomerização, polimerização e alquilação (NEIVA, 2003). Há a AVGAS que é um tipo de combustível utilizado em veículos aeronáuticos e os dois principais tipos de gasolina comercializados internacionalmente são AVGAS 100LL (recebe corante azul) e AVGAS 100 (recebe corante verde), possuindo ótimas performances em motores de aviões, devem operar bem em baixas temperaturas e baixas pressões, devem ser disponíveis em grandes quantidades e devem receber aditivos especiais para as condições específicas dado o comportamento do combustível em condições de grandes altitudes (informação online) ${ }^{11}$. A tabela (4.2) apresenta um resumo das principais variedades de gasolina comercializadas em território brasileiro.

\footnotetext{
${ }^{10}$ Material extraído do website da empresa Shell. <http://www.shell.com.br> Acesso em 01 abr. 2008.

${ }^{11}$ Material publicado pelo departamento de Engenharia Mecânica da Universidade Federal de Minas Gerais (UFMG) em seu website: <http://www.demec.ufmg.br/site/inicio/index.phpr/>. Acesso em 22 de outubro de 2008.
} 
Tabela 4.3 Principais variedades da gasolina brasileira

\begin{tabular}{|c|c|c|c|c|c|c|}
\hline Combustivel & Tipo & IAD & $\begin{array}{c}\text { Adição de } \\
\text { Etanol } \\
\end{array}$ & Aditivos & $\begin{array}{c}\text { Enxofre } \\
\text { (\%massa) }\end{array}$ & Coloração \\
\hline Gasolina & "A" & 73 & $0 \%$ & Não & 0,07 & Amarela \\
\hline Gasolina & "B" & 83 & $0 \%$ & $\mathrm{ND}$ & $\mathrm{ND}$ & Azul \\
\hline Gasolina Comum & "C" & 87 & $25 \%$ (vol) & Não & 0,07 & Nenhum \\
\hline Gasolina Aditivada & "C" & 87 & $25 \%$ (vol) & Sim & 0,05 & Verde \\
\hline Gasolina Premium & "C" & 91 & $25 \%(\mathrm{vol})$ & Sim & $\mathrm{ND}$ & Nenhum \\
\hline Gasolina Podium & "C" & 95 & $25 \%(\mathrm{vol})$ & Sim & ND & Alaranjado \\
\hline Gasolina Aeronáutica & $\mathrm{ND}$ & $110-130$ & ND & $\mathrm{ND}$ & $\mathrm{ND}$ & AzulfVerde \\
\hline
\end{tabular}

*ND: Dados não disponíveis.

Fonte: (informação online) ${ }^{12}$; Elaboração Própria.

Segundo Ferreira; Flumignam e Oliveira (2007) a gasolina automotiva é um dos combustíveis fósseis mais utilizados no mundo, havendo um grande interesse por parte da sociedade em relação à sua qualidade e em se tratando do Brasil, a gasolina automotiva foi responsável, em 2005, por 26,53\% das vendas de derivados de petróleo pelas distribuidoras, totalizando um volume de $23.541,80 \mathrm{~m}^{3}$ comercializados. Infelizmente, a gasolina é o combustível mais adulterado no mercado nacional, trazendo sérios riscos ao motor do veículo além de prejuízos aos cofres públicos devido à sonegação de impostos. Uma gasolina ordinária é constituída, como já foi mencionado anteriormente, por hidrocarbonetos derivados de petróleo e pode conter aditivos que melhoram seu rendimento sendo seu controle de qualidade realizado pela Agência Nacional do Petróleo, Gás Natural e Biocombustíveis (ANP) e além da grande importância de um controle como esse é garantir um produto isento de agentes adulterantes, diminuindo assim a sonegação de impostos, os riscos à saúde da população, danos ambientais e os danos causados aos motores dos veículos. De acordo com Balabin e Safieva (2007) a correta identificação da gasolina é um fator importante para seu controle de qualidade e identificação de possíveis adulterações sendo que a diferença na composição do petróleo - que pode variar de acordo com a localização de sua reserva resulta em diferenças químicas na gasolina de uma refinaria para outra e conhecer o tipo da gasolina é fundamental para determinação de sua qualidade, seu preço e conseqüentemente seu comportamento no mercado de combustíveis.

\footnotetext{
${ }_{12}$ Material publicado pelo departamento de Engenharia Mecânica da Universidade Federal de Minas Gerais (UFMG) em seu website: <http://www.demec.ufmg.br/site/index.php/>. Acesso em 22 de outubro de 2008.
} 


\subsection{2 Óleo Diesel}

O combustível conhecido como óleo diesel, assim como a gasolina, é um produto da petroquímica tradicional, sendo obtido primordialmente pela destilação fracionada do petróleo, destilando até $300{ }^{\circ} \mathrm{C}$ em pressão atmosférica, conforme indicado pela figura (4.2), e constituído basicamente por hidrocarbonetos contendo de 12 a 16 átomos de carbono e alguns contaminantes derivados do enxofre e do nitrogênio; apresenta-se como um líquido inflamável, tóxico, volátil e possuidor de odor característico, sendo uns dos combustíveis mais utilizados no mundo moderno. O combustível final óleo diesel resulta da mistura de diversas frações do petróleo, como o diesel pesado, o diesel leve, querosene e nafta, visando o resultado mais adequado e menos poluente para o uso; foi batizado em homenagem ao engenheiro alemão Rudolf Cristian Karl Diesel (1858-1913), notório idealizador de um dos mais revolucionários sistemas mecânicos da história: um motor de combustão interna que aproveitava a energia liberada pela explosão decorrente de uma reação química entre um óleo derivado do petróleo e o oxigênio $\left(\mathrm{O}_{2}\right)$; o cientista levou aproximadamente 12 anos para finalizar seu experimento - um motor de ignição por compressão (ciclo diesel) - e foi preciso elaborar muitos outros aparatos capazes de viabilizar seu projeto, tendo sua patente registrada em 23 de fevereiro de 1897. O óleo mais abundante naquela época, obtido pelo refino do petróleo, o óleo diesel, permaneceu associado ao motor, contudo o mesmo suportava outros tipos de óleos desde que sofresse os devidos ajustes e foi com o passar do tempo que a invenção de Rudolf Diesel se espalhou pelo mundo produtivo em substituição ao vapor empregado nos maquinários utilizados para gerar trabalho em locomotivas e embarcações marítimas e em motores independentes para geração de energia elétrica, causando assim uma revolução no mundo industrial próximo do final do século XIX.

De forma distinta dos motores que operam pelo ciclo Otto (ignição por centelha), nos motores do ciclo Diesel, a combustão se dá por auto-ignição do combustível e ocorre quando o ar é submetido à devida compressão pelo pistão, dentro do cilindro de admissão, aumentando dessa forma sua temperatura e em seguida o combustível é injetado diretamente na câmara de combustão, momentos antes da combustão ser iniciada - o espaço de tempo compreendido entre o começo da injeção e o início da combustão é denominado atraso de ignição, ocorrendo em decorrência do período de tempo necessário para a pulverização do combustível, seguido pelo seu aquecimento, mistura com o ar, reações químicas e, finalmente, a auto-ignição, provocando a combustão da mistura combustível, gerando uma explosão e 
movimentando o pistão, produzindo trabalho útil dessa forma (informação online) ${ }^{12}$. $\mathrm{O}$ manuseio do óleo diesel requer alguns cuidados, por exemplo ao se lidar com sua frações mais leves o risco de inflamabilidade aumenta dada sua alta volatilidade, demandando maiores cuidados no que se refere aos métodos de transporte e armazenamento do mesmo; já as frações mais pesadas devem ser observadas dada sua difícil vaporização, uma vez que a mesma é totalmente necessária no momento de injeção do combustível na câmara de combustão. É importante atentar para a densidade do óleo diesel dado o fato de que a bomba injetora disponibiliza volumes constantes de combustível para o motor, dependendo qual a condição de operação demandada. Se ocorrer variação na densidade do óleo, conseqüentemente, haverá variação na massa injetada, acarretando em perda de potência ou aumentando as emissões de material particulado, hidrocarbonetos que não foram queimados e também monóxido de carbono.

Além desses subprodutos da combustão, ainda há o enxofre que representa um dos mais nocivos e indesejáveis contaminantes do óleo diesel devido à ação corrosiva de seus compostos e à formação de gases como o dióxido de enxofre e trióxido de enxofre que, além de tóxicos, podem originar o ácido sulfúrico dentro do motor ou na atmosfera. Atualmente a matriz energética brasileira apóia-se também no transporte de cargas utilizando veículos equipados com motores diesel, fazendo com que o óleo diesel seja, no Brasil, o derivado propulsor do refino do petróleo - seu volume corresponde a $34 \%$ do volume total do barril de petróleo; em outros países essa demanda pode variar de $15 \%$ a $25 \%$.

No Brasil é comercializado pelo Petrobras Distribuidora SA - Petróleo S/A o diesel podium, um tipo de combustível premium de melhor desempenho, fabricado para veículos comerciais como pickups e veículos utilitários esportivos, possuindo um NC de 51, o menor teor de enxofre se comparado aos outros óleos diesel comercializados no mercado brasileiro e ainda possui uma composição diferenciada e aditivada atuando como agente detergente mantendo limpo o sistema de alimentação do motor, evitando entupimentos e reduzindo a freqüência e o custo das manutenções; o diesel podium é comercializado ainda em um número restrito de postos de abastecimento no país, limitado, por enquanto, a algumas regiões metropolitanas de São Paulo, Rio de Janeiro e Paraná. (PETROBRAS - DISTRIBUIDORA S.A., 2008) 


\subsubsection{Variedades do óleo diesel}

De acordo com suas aplicações, o óleo diesel pode ser classificado em (1) óleo diesel automotivo, sendo esse subdivido em: (a) óleo diesel interior que possui um teor máximo de enxofre de $0,35 \%$ e é utilizado em cidades cuja frota veicular em circulação é grande e as condições geográficas e climáticas são desfavoráveis para a dispersão dos gases de combustão; (b) extra diesel aditivado que é um combustível possuidor de aditivos que atuam como agentes detergentes no sistema de injeção de combustível, reduzindo assim o desgaste dos bicos injetores, formação de sedimentos e garantindo uma proteção anticorrosiva no sistema de alimentação; sua utilização proporciona uma pulverização mais eficaz permitindo uma mistura mais homogênea do ar com o combustível, acarretando em diversos ganhos de eficiência e qualidade do ar; (c) óleo diesel padrão que é produzido unicamente para as montadoras de veículos automotivos movidos a óleo diesel para ser utilizado na homologação dos motores durante baterias de testes de desempenho e consumo; e (2) óleo diesel marítimo, subdividido em (a) óleo diesel marítimo comercial que é semelhante ao diesel convencional apresentando apenas um valor diferenciado para seu ponto de fulgor $\left(60^{\circ} \mathrm{C}\right.$ ao invés de $38^{\circ} \mathrm{C}$, conforme Portaria $n^{\circ} 310$ da ANP, de 27/12/2001), que se entende por ser a mais baixa temperatura que o diesel vaporiza em quantidade capaz de, juntamente com o ar, formar uma mistura explosiva, podendo inflamar momentaneamente se atingida por uma fonte ignitora; (b) óleo diesel especial para Marinha e Ártico é um combustível especial fabricado para atender às necessidades militares, apresentando características específicas para suportar condições adversas de embarcações marítimas sob baixas temperaturas. Seguindo as determinações do DNC, a Petrobras Distribuidora SA - Petróleo Brasileiro S/A classifica os óleos diesel brasileiros em: "A" (diesel automotivo) comercializado no país até o ano de 1998, exceto em algumas capitais, porém, atualmente está fora de linha de produção, tendo sido substituído pelo óleo diesel tipo "B"; "B" (diesel metropolitano) comercializado em todos todas as regiões metropolitanas do país desde janeiro de 2008 e possui teor máximo de enxofre fixado em $0,5 \%$; “C” foi comercializado no país de acordo com um programa que visava melhorar a qualidade do óleo diesel, tendo deixado de ser produzido desde janeiro do ano 2000; e "D" (diesel marítimo) especial para embarcações marítimas e uso militar. A tabela (4.3) resume as principais classificações do óleo diesel brasileiro (PETROBRAS DISTRIBUIDORA S.A., 2008). 
Tabela 4.4 Principais variedades do óleo diesel brasileiro

\begin{tabular}{||l|c|c|c||}
\hline Combustivel & Tipo & NC (nín.) & $\begin{array}{c}\text { Enxofre } \\
\text { (\%massa) }\end{array}$ \\
\hline \hline Óleo diesel automotivo (extinto) & "A" & 40 & 1,0 \\
\hdashline Oleo diesel metropolitano & "B" & 40 & 0,5 \\
\hline Oleo diesel (extinto) & "C" & 42 & 0,3 \\
\hdashline Oleo diesel marítimo & "D" & 42 & 1,0 \\
\hline Oleo diesel podium & "B" & 51 & 0,2 \\
\hline \hline
\end{tabular}

Fonte: (informação online) ${ }^{13}$; Elaboração Própria.

Há ainda o combustível ultra-low sulphur diesel (ULSD) que consiste em um óleo diesel definido assim por conter reduzidos valores de enxofre tendo sido adotado, desde 2006, em todos os países da UE e EUA; assim como o ULSD ainda existem inúmeros outros tipos de óleos diesel, por exemplo o S-500, ou o BP Ultimate Diesel, desenvolvido pela Beyond Petroleum (BP) possuindo um NC de 55 - mais alto do que a maioria dos combustíveis convencionais, assegurando dessa forma uma melhor combustão, logo, um melhor desempenho e menor emissão de agentes poluentes (informação online) ${ }^{14}$; cada um com especificações distintas para atender os mais variados nichos de mercado e muitos outros se encontram em fase de pesquisas para um contínuo aprimoramento.

\subsection{Biocombustíveis sintéticos}

Apresentados como alternativas aos combustíveis de origem fóssil, os biocombustíveis caracterizam-se como um combustível sólido, líquido ou gasoso obtido pelo emprego de matéria-prima renovável e sustentável definida como biomassa - englobando suas inúmeras variedades, como plantas oleaginosas, biomassa florestal ou culturas orgânicas que podem ser renovadas a curto prazo - em seus processos produtivos.

\footnotetext{
13 Material extraído do website da empresa brasileira Petrobras Distribuidora S/A disponível em <http: http://www.br.com.br/portalbr/calandra.nsf $>$. Acesso em 27 de novembro de 2008.

${ }^{14}$ Material extraído do website da empresa britânica Beyond Petroleum (antiga British Petroleum) disponível em $<$ http:www.bp.com>. Acesso em 24 de outubro de 2008.
} 
De acordo com Probstein e Hicks (1982) os combustíveis sintéticos são aqueles obtidos pela conversão de uma determinada forma de material carbonado em outra forma como ocorre nos processos CTL e GTL, por exemplo, em que a partir do carvão mineral e do gás natura,l respectivamente, se obtem um importante insumo de produção denominado gás de síntese para que, partindo-se do mesmo, sintetize-se gasolina e diesel, dentre outros produtos. A união dessas duas definições remete ao conceito de biocombustíveis sintéticos em que a obtenção de um elemento combustível depende da conversão de uma matéria-prima carbonada, nesse caso, especificamente a biomassa, extraindo dela o gás de síntese (biosyngas) e a partir dele se obtem combustíveis veiculares pela utilização de uma síntese química conhecida como Biomass-to-Liquids (BTL), cujo princípio pode ser demonstrado pela figura (4.3).

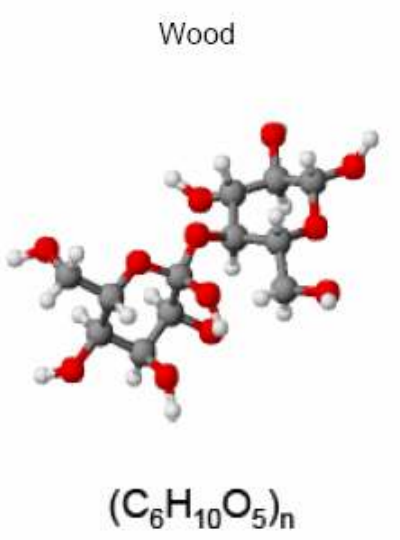

$$
\text { Synthesis Gas } \begin{gathered}
\text { Hydrocarbon } \\
\text { Building Stone }
\end{gathered}
$$
Diesel, etc.

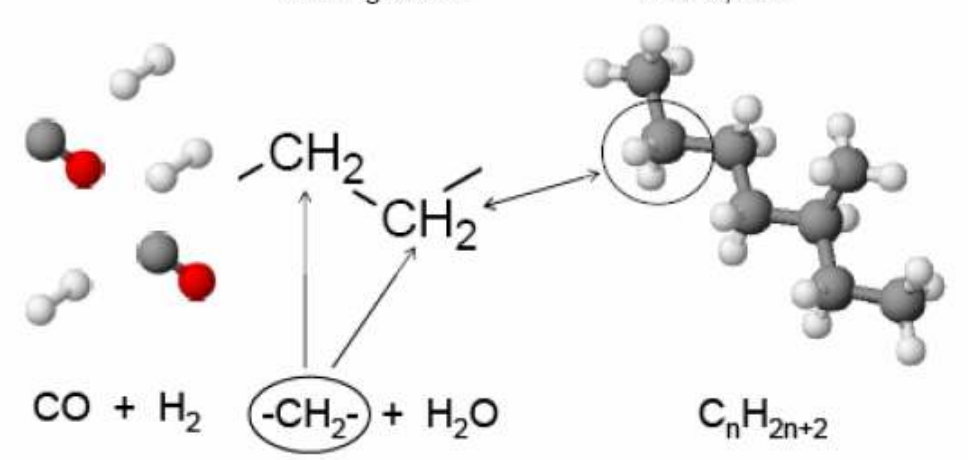

Figura 4.3 Princípio da síntese de hidrocarbonetos a partir de matéria-prima carbonada Fonte: (OPDAL, 2006)

Inicialmente os biocombustíveis eram produzidos através do cultivo de plantas com elevado teor de açúcares, como a cana-de-açúcar e a beterraba, por exemplo, para que, em seguida, esses açúcares fossem fermentados proporcionando o álcool etílico ou etanol; outra possibilidade era a cultura de espécies vegetais oleaginosas, ou seja, ricas em óleos vegetais, como a soja, a palma, dentre outras, para obtenção do óleo contido e, após devido processamento, o mesmo tornar-se-ia biodiesel e poderia ser queimado em motores do tipo diesel. Os biocombustíveis oferecem uma possibilidade menos poluente de se produzir energia e com um menor comprometimento no que tange à liberação de carbono na atmosfera, dada as emissões de dióxido de carbono, além de reduzir a dependência dos combustíveis da petroquímica tradicional tendo impacto nos preços mercado internacional; outras vantagens 
podem ser a redução do desmatamento e erosão de solos e também uma redução sobre o impacto de recursos hídricos e comunidades tradicionais associadas àquela geografia.

Já os combustíveis sintéticos utilizam complexas rotas tecnológicas para "construírem" os hidrocarbonetos que originarão os combustíveis a partir de unidades monoméricas ou outras rotas químicas que partem do metanol, por exemplo, ressaltando que todas são originadas pela aplicação do gás de síntese em um primeiro momento, seja ele obtido a partir do carvão (CTL) ou do gás natural (GTL) e, posteriormente, da biomassa, através da rota BTL. A figura (4.3), extraída do Plano Nacional de Energia 2030, apresenta as rotas tecnológicas de conversão da biomassa para fins energéticos agrupadas em três caminhos fundamentais, dividindo-se em:

(a) conversão termoquímica em que a energia química presente na biomassa é convertida em calor por meio da combustão direta, gaseificação ou pirólise;

(b) conversão bioquímica em que agentes biológicos e químicos são responsáveis pela destilação, hidrólise e fermentação anaeróbia; e

(c) conversão físico-química que utiliza técnicas de compressão e esmagamento de diversas matérias-primas vegetais, obtendo-se assim diversos óleos vegetais que, em seguida, sofrerão conversões químicas.

Todas essas formas de conversão energética apresentam-se de maneiras distintas e delas ramificam-se muitos outros caminhos secundários de aproveitamento energético e produção de biocombustíveis. 


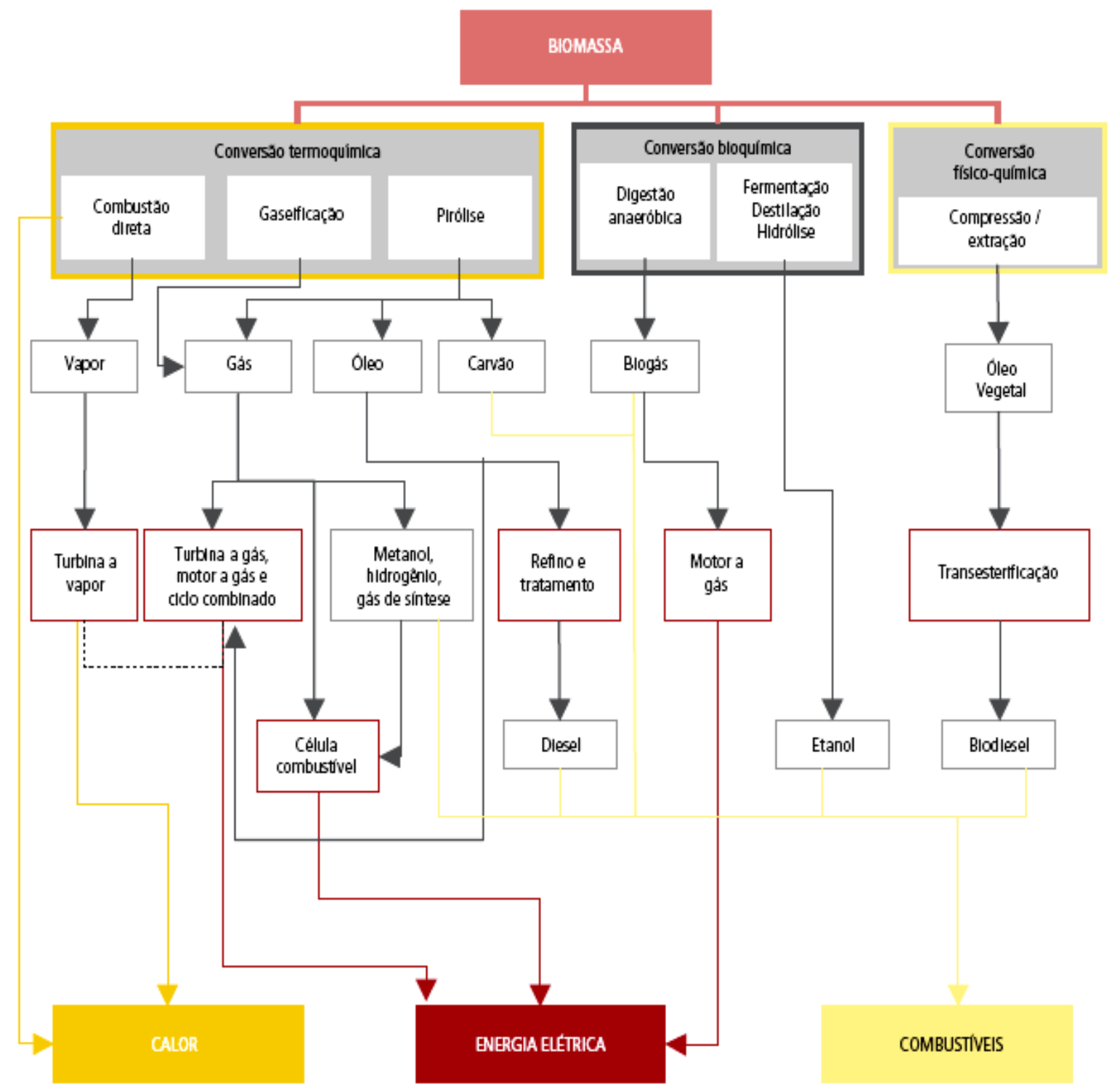

Figura 4.4 Rotas tecnológicas de conversão da biomassa

Fonte: (LARKIN; RAMAGE; SCURLOCK apud BOYLE, 1996)

\subsubsection{Contexto histórico}

No começo do século XX, de acordo com Dunham; Bomtempo e Almeida (2006), ocorreu o desenvolvimento dos motores a combustão interna que acarretou numa ruptura com a fonte de energia até então utilizada nas máquinas a vapor, o carvão mineral e, além dos inúmeros benefícios, o uso dos modernos motores gerou a rígida necessidade de combustíveis líquidos para o seu funcionamento o que, atualmente, representa uma gigantesca demanda em 
todo o mundo, ainda mais dado o contínuo aumento dessa frota. Para suprir essa demanda de combustíveis líquidos os processos de refino e transformação do petróleo foram primordiais no atendimento às necessidades em curso, constituindo até hoje a trajetória tecnológica dominante, sendo válido destacar que os fatores econômicos são importantes parâmetros no momento de seleção dos programas de pesquisa e desenvolvimento (P\&D) a serem implementados, uma vez que se mostram fundamentais para a definição dos recursos financeiros, materiais e humanos que serão alocados nos esforços tecnológicos. Assim, os parâmetros econômicos são os que definem o ambiente de seleção das diferentes trajetórias tecnológicas, viabilizando-as de acordo com a variação na cotação internacional do petróleo.

Foi em meados do século passado XX, no o início da II Guerra Mundial, que uma nova trajetória tecnológica veio a desafiar o refino do petróleo como tecnologia dominante, onde muitos programas de $\mathrm{P} \& \mathrm{D}$ resultaram em processos de obtenção de combustíveis sintéticos, obtidos por insumos que não eram necessariamente provenientes do óleo bruto e seus tradicionais processos de refino. Historicamente sabe-se que esta nova possibilidade foi de fundamental importância para países como a Alemanha e o Japão por terem sofrido um forte embargo comercial dos países aliados e, mais uma vez, nos últimos anos, fatores econômicos e agora também ambientais, ainda que diferentes dos experimentados ao longo da do período de guerra, reacendem o interesse nos processos de obtenção de combustíveis sintéticos, uma relativamente nova trajetória tecnológica.

Observando um pouco o passado, ao final do século XIX, as necessidades de insumos energéticos eram supridas basicamente pela utilização do carvão mineral, atendendo plenamente ao uso doméstico (especialmente nos países mais frios, para o aquecimento interno) e industrial (em sua maior parte através da queima e produção de vapor). Entretanto, o processo de urbanização e industrialização da Europa no início do século XX tornou necessária a substituição do carvão por fontes energéticas mais eficientes e limpas, e os combustíveis líquidos derivados do petróleo atendiam plenamente aos requisitos estabelecidos, possibilitando o desenvolvimento de novos motores de combustão interna, especialmente os que operavam através dos ciclos Otto e Diesel. Essa mudança teve como resultado o emprego dos motores de combustão interna em veículos terrestres, aeronaves e embarcações marítimas, trazendo consigo um novo paradigma tecnológico para o setor energético: a obtenção de combustíveis líquidos como a gasolina, o óleo diesel, o querosene e outros óleos combustíveis. A trajetória tecnológica que tem predominado a fim de objetivar uma solução para problema definido pelo paradigma apresentado é o refino e processamento do petróleo, constituindo um pilar primordial para obtenção desses combustíveis veiculares e 
neste sentido, as primeiras décadas do século XX foram essenciais para o aperfeiçoamento de tecnologias refino na indústria petrolífera (STRANGES, 1997).

\subsubsection{Primeira trajetória tecnológica em combustíveis sintéticos}

Conforme Dunham et al. (2003) são indiscutíveis os avanços tecnológicos proporcionados pela indústria petrolífera mesmo com a crescente dependência do petróleo como insumo energético, o que veio a provocar um impacto negativo na balança comercial dos países que não dispunham de fontes naturais de óleo cru. Países como a Alemanha e o Japão, que se encontravam em fase crescente dos níveis de industrialização, foram significativamente afetados e era fato que os países mais dependentes do petróleo importado dispunham, sobre o seu domínio, de consideráveis reservas de outro valioso combustível fóssil: o carvão mineral, largamente utilizado como fonte energética. É possível verificar-se um esforço no sentido de aproveitar o carvão como principal fonte de carbono para a obtenção de combustíveis líquidos e foi a Alemanha, país pioneiro nas atividades de P\&D no campo de pesquisa dos combustíveis sintéticos, o primeiro a contar com fortes recursos estatais para dar prosseguimento à busca por sólidas tecnologias. Com a ascensão do regime nazista houve um impulso ainda maior na indústria de combustíveis sintéticos, cujo sucesso era imprescindível para viabilizar o plano de expansão militar do país no período da II Guerra Mundial e dessa forma houve o surgimento de uma nova trajetória tecnológica, cujo objetivo maior era o aproveitamento e a transformação do carvão mineral extraído em combustíveis líquidos sintéticos para uso veicular, possibilitando também, dessa forma, suprimentos energéticos para o setor industrial e, principalmente, para o abastecimento das tropas alemãs em tempos de guerra. As pesquisas no campo tecnológico e de desenvolvimento resultaram em três novos processos de transformação, sendo eles: (1) a conversão do carvão mineral sob baixas temperaturas, o processo Low Temperature Conversion (LTC); (2) o processo de hidrogenação do carvão e (3) o processo Fischer-Tropsch (STRANGES, 1997).

Conforme é apontado por Pinheiro (2002) e Dunham et al. (2003) o processo LTC consistia em um craqueamento do carvão na ausência de catalisadores e ar, com uma temperatura que variava entre $500{ }^{\circ} \mathrm{C}$ e $700{ }^{\circ} \mathrm{C}$ sendo um processo simples; já o processo de hidrogenação do carvão foi desenvolvido em Hannover, maior cidade da Baixa Saxônia, Alemanha, entre os anos de 1910 e 1925 pelo químico e industrial alemão Friedrich Bergius 
(1884-1949); tendo sido muito estudado durante as duas grandes guerras mundiais, esse processo consistia numa mistura de carvão mineral pulverizado com um solvente adequado que, dentro de condições específicas, era hidrogenado e se decompunha nos produtos de interesse. $\mathrm{O}$ processo desenvolvido por Bergius pode ter se baseado em relatos históricos datados de 1792 quando, segundo Shnidman apud Probstein e Hicks (1982), Murdoch, um engenheiro escocês, teria destilado o carvão mineral em um dispositivo de ferro e utilizado o gás obtido para iluminar sua residência, gás esse que, a partir de 1812, seria utilizado para iluminação pública, começando na cidade de Londres, no Reino Unido - acredita-se que esse gás teria sido descoberto, inicialmente, por Fontana, em 1780, possuindo um poder calorífico de aproximadamente $11 \mathrm{MJm}^{-3}$, porém o mesmo viria a cair em desuso, tanto na Europa quantos nos EUA, nos anos que se seguiram à II Guerra Mundial. Finalmente, conforme aponta Berkowitz e Storch apud Probstein e Hicks (1982), nos anos da década de 1920, o mais complexo dos processos, que ficou conhecido pelo nome dos seus idealizadores, os pesquisadores Franz Fischer e Hanz Tropsch, consistia na geração de uma mistura gasosa de hidrogênio $\left(\mathrm{H}_{2}\right)$ e monóxido de carbono $(\mathrm{CO})$, denominada gás de síntese (syngas) que, em contato com um catalisador específico em condições adequadas de temperatura e pressão, se convertia numa mistura de diversos tipos de hidrocarbonetos; a princípio esse gás de síntese era obtido por meio da passagem de vapor d'água sobre o carvão mineral em condições controladas sendo também possível, em um segundo momento, sua obtenção através do gás natural.

Um importante ponto do processo FT esta relacionado à engenharia dos equipamentos empregados, uma vez que a conversão do gás de síntese em hidrocarbonetos é altamente exotérmica e, dessa forma, o desenho de reatores e sistemas de resfriamento guiaria uma considerável parte dos interesses das equipes de $\mathrm{P} \& \mathrm{D}$, que tenderiam a se tornar cada vez mais exigentes de acordo com os avanços tecnológicos e conforme o processo fosse mais bem compreendido ao longo dos anos; de igual importância era obtenção de eficientes catalisadores metálicos capazes de otimizar o processo, demandando sólidos conhecimentos por parte de seus pesquisadores no campo da química inorgânica e da ciência dos materiais.

Historicamente sabe-se que os avanços mais significativos foram obtidos pela Alemanha, Japão e Estados Unidos - neste último, segundo Pinheiro (2002), viabilizados, em parte, pelo projeto batizado de "Paperlip", que trouxe 1.600 cientistas alemães para desenvolver pesquisas no país, dentre elas, a produção de combustíveis sintéticos, tendo o projeto durado de 1945 até 1968; houve também o Synthetic Fuel Liquids Act, promulgado em 1944, que objetivava um aprofundamento dos estudos e análise das possibilidades de 
produção líquidos FT em escala comercial, fazendo com que o Bureau of Mines viabilizasse a construção de duas plantas-piloto em território norte-americano: uma de hidrogenação do carvão e a outra da síntese FT via rota CTL em Louisiana, Missouri. Os três países, além das atividades de $\mathrm{P} \& \mathrm{D}$, tiveram unidades piloto e comerciais em funcionamento e apesar dos intensos e significativos esforços em viabilizar novos processos, todos se mostraram impossíveis do ponto de vista econômico, tendo os avanços experimentais e a implementação de unidades produtivas sendo justificadas somente pelo desenrolar da II Guerra Mundial. Devido à baixa eficiência técnica alcançada naquela época e aos altos investimentos em maquinários, não era justificada a manutenção das unidades existentes e, de forma adicional, soma-se o fato da eminência da guerra fria, sob a pressão dos países aliados, em especial dos EUA., forçando o fechamento das unidades produtivas na Alemanha. Já no Japão, os processos apresentavam índices insatisfatórios de desenvolvimento técnico nos procedimentos e as instalações de $\mathrm{P} \& \mathrm{D}$, assim como as unidades já construídas, foram devastadas pelos bombardeiros aliados, impedindo que o país mantivesse sua expectativa, a curto e médio prazo, de retomar aquelas atividades industriais. Nos EUA, as pressões exercidas por parte da gigantesca indústria petrolífera norte-americana, que enxergava naquelas tecnologias alternativas uma espécie de ameaça aos seus mercados, se fizeram valer no processo de descontinuidade das atividades de P\&D e das plantas-piloto que operavam pelas rota FT, mesmo que as tecnologias não estivessem, de alguma forma, sendo utilizadas para substituir os combustíveis veiculares oriundos da petroquímica tradicional. Assim, na maior parte do mundo que a desenvolvia, houve uma interrupção dessa tecnologia.

\subsubsection{Trajetória tecnológica no pós-guerra: África do Sul}

Os argumentos expostos anteriormente, a inviabilidade econômica de manutenção das plantas e diversas questões políticas foram decisivas para a descontinuidade das atividades de P\&D após a II Guerra Mundial no que tangia a síntese FT, e mais ainda após o começo da década de 1950. Contudo, de acordo com Pinheiro (2002), um caso singular de continuidade de desenvolvimento nessa trajetória tecnológica de combustíveis líquidos pode ser observada na África do Sul, uma vez que o governo sul-africano tinha como principal meta superar as dificuldades de importação de petróleo e derivados impostas pelo embargo internacional ao país, em função do regime político em vigor conhecido como Apartheid. Dunham et al. 
(2003) apontam que, ademais a produção de combustíveis sintéticos, o governo sul-africano também objetivava viabilizar a produção de diversos insumos da indústria petroquímica de base como solventes orgânicos, amônia, dentre outros, fazendo com que a implantação de unidades que utilizassem a tecnologia da síntese FT se justificassem pela experiência internacional no processo durante os anos de guerra. É válido destacar que a África do Sul não possuía reservas relevantes de petróleo capazes de satisfazer a demanda interna do país, fosse ela por combustíveis ou por insumos petroquímicos, em contrapartida seu território possuía abundantes reservas de carvão mineral e assim, baseando nas necessidades energéticas do país, foi fundada, em Sasolburg, no ano de 1950, a South African Coal, Oil and Gas Corporation Limited - Sasol, empresa que tornar-se-ia responsável pela produção de combustíveis líquidos sintéticos tendo como principal insumo o carvão mineral: esta tecnologia tornou-se conhecida como rota CTL (Coal-to-Liquids).

No ano de 1951 teve início a construção da primeira planta industrial, localizada no norte do país, e assim se seguiram quatro anos de construção, terminando quando a unidade batizada de Sasol I ficou pronta; nela eram utilizados catalisadores à base de ferro e cobalto, operado com baixas temperaturas. Em operação a planta era responsável pela produção não apenas dos objetivados combustíveis sintéticos, como a gasolina e óleo diesel principalmente, mas a unidade também produzia componentes da indústria petroquímica, como solventes para tintas e amônia; contudo a produção de combustíveis ia se mostrando pouco viável economicamente dados os baixos preços do petróleo internacional, justificando assim a crescente necessidade da implementação de unidades de refino de petróleo e foi assim que, ao findar a década de 1960 o governo sul-africano diversificou sua atuação, iniciando a importação e o refino do petróleo em seu território. Uma nova empresa foi criada e podia contar com parcerias internacionais, entretanto, a crise na indústria petrolífera de 1973 forçou o governo sul-africano a direcionar, novamente, todos os esforços produtivos do país na direção dos combustíveis sintéticos provenientes da síntese FT. Três anos mais tarde, no ano de 1976, teve início a construção da segunda planta de produção de combustíveis sintéticos, a Sasol II, localizada em Mpumalanga, em Secunda, África do Sul, e aproximadamente tinha o dobro da capacidade de produção da primeira unidade, tendo sido concluída no ano de 1980. Assim como a Sasol I, essa segunda planta também produzia gasolina e o óleo diesel sintéticos, assim como outros óleos combustíveis e operava com altas temperaturas. Antes do término da construção da Sasol II teve início a construção da terceira planta, a Sasol III, fazendo uso da mesma tecnologia, mantendo a mesma capacidade produtiva de sua predecessora, localizando-se também no complexo industrial da cidade de Secunda, África do 
Sul. Atualmente, a Sasol é um complexo petroquímico bilionário que emprega mais de 30 mil colaboradores tendo se tornado uma referência internacional para o mercado de combustíveis sintéticos.

\subsubsection{Segunda trajetória tecnológica em combustíveis sintéticos}

Conforme é apontado por Pinheiro (2002) a segunda trajetória tecnológica em combustíveis sintéticos iniciou-se em Mossel Bay, na África do Sul, concretizando-se com a criação da Mossgas, atual Petro S.A., sendo esta uma grandiosa empresa estatal destinada à produção de combustíveis sintéticos líquidos, com uma capacidade produtiva de 34.000 barris/dia, tendo sido concluída no ano de 1987 e podendo contar com a tecnologia capaz de converter o gás natural disponível em suas reservas para a produção de combustíveis sintéticos veiculares, como a gasolina e o óleo diesel, além de querosene e demais produtos da indústria petroquímica através da rota que ficou conhecida como GTL (Gas-to-Liquids). O investimento da planta era justificado pela existência das reservas de gás natural assim como pelas previsões nada otimistas que o mercado apresentava em relação aos preços do petróleo.

Segundo é mencionado em Hartog apud Dunham, Bomtempo e Almeida (2006) no ano de 1993 a gigantesca Shell construiu aquela que seria a segunda planta comercial utilizando o GN como matéria-prima, em Bintulu, Sarawak, na Malásia; essa planta possuía a capacidade de produzir mais de 12.000 barris/dia; todavia teve suas atividades encerradas no ano de 1997 em função de uma explosão ocorrida no sistema de separação de ar. Contudo, a planta foi reconstruída e vem operando normalmente desde o ano 2000. Mesmo a síntese FT representando uma das atuais opções tecnológicas disponíveis para produção de combustíveis veiculares - e da existência de uma planta industrial em operação - ainda serão necessários significativos avanços que possibilitem a viabilidade econômica dos produtos obtidos.

É apontado por Dunham et al. (2003) que os complexos industriais que geram gás de síntese (syngas) correspondem a cerca de $50 \%$ dos custos de investimento das unidades produtivas que utilizam a síntese FT para obtenção de combustíveis líquidos, sendo esse processo um ponto crucial dos programas de $\mathrm{P} \& \mathrm{D}$ e muitos avanços tecnológicos têm sido alcançados por empresas como a Sasol e a química e petroquímica dinamarquesa HaldorTopsoe, fundada na década de 1940. O desenvolvimento conquistado pode contribuir de 
forma significativa para a eficiência global dessa rota química (GTL) norteando uma viabilidade econômica e, conseqüentemente, a comercialização dos combustíveis sintéticos.

Estudos em contraposição ao processo FT apresentam, segundo Martín apud Dunham et al. (2003), uma possível tecnologia de conversão direta que consistiria na conversão direta do gás natural em produtos de interesse comercial, como combustíveis e outros derivados petroquímicos, em uma operação de etapa única, uma rota unitária, que não necessitará do gás de síntese como produto intermediário; essa proposição, a conversão direta, representa uma fronteira tecnológica em curso uma vez que os processo em si é complexo e as reações envolvidas ainda necessitam de maior conhecimento dada a natureza estável da molécula do metano $\left(\mathrm{CH}_{4}\right)$, principal componente do gás natural. Em um cenário otimista onde o sucesso dessa tecnologia é real, ter-se-á uma inovação no que tange a produção de combustíveis sintéticos e a implementação de um processo como esse proporcionaria a exclusão dos gastos relacionados à construção, operação e manutenção das unidades de gás de síntese, responsáveis por consideráveis investimentos nas plantas de combustíveis sintéticos líquidos.

\subsubsection{Primeira geração de biocombustíveis}

$\mathrm{Na}$ atualidade o etanol, ou álcool etílico combustível, e o biodiesel, notórios biocombustíveis, estão presentes em praticamente todos os importantes mercados de combustíveis líquidos, sendo eles os dois principais representantes da primeira geração de biocombustíveis, participando ativamente da matriz energética mundial e de inúmeros estudos dos mais diversos campos, como científico, social e econômico. Os biocombustíveis da primeira geração utilizam, primordialmente, como matéria-prima, produtos derivados das atividades agrícolas e agroindustriais como principal insumo de produção por exemplo o etanol de cana-de-açúcar ou milho, e o biodiesel de espécies vegetais oleaginosas, como a soja, girassol etc. A começar pelo etanol, ou álcool etílico, este se apresenta como um líquido incolor, inflamável, de odor e sabor característico; pertence ao grupo orgânico dos álcoois moléculas que contêm um grupo hidroxila ligado a um carbono - possuindo ponto de fusão em $-114,1{ }^{\circ} \mathrm{C}$, de ebulição em $78{ }^{\circ} \mathrm{C}$, sendo menos denso do que a água. Basicamente é possível citar três processos para obtenção do etanol: a hidratação do eteno, o mais simples dos alcenos; a redução do acetaldeído ou etanal; e por fim o mais conhecido de todos, a fermentação, que ocorre pela ação da enzima diástase (ou maltase) que converte o amido em 
açúcares e depois sofre ação de outra enzima, a zimase, convertendo os açúcares em álcool. O etanol produzido dessa forma atinge baixos valores na solução resultante por razões naturais contudo, pode ser concentrado por destilação até o ponto máximo de $96 \%$, não sendo possível obtê-lo de forma pura apenas pelo processo de destilação, sendo necessária a utilização de agentes desidratantes ou através de síntese química. Atualmente existem grandiosas refinarias produzindo etanol de cana-de-açúcar, principalmente no Brasil, e de milho, nos EUA, para suprir a crescente demanda por biocombustíveis (informação online) $)^{15}$.

A história do etanol data de 1927, na Usina Serra Grande Alagoas, a primeira a produzi-lo como combustível veicular. Porém somente nos anos da década de 1970, com a crise internacional do petróleo, foi que esse combustível recebeu o devido reconhecimento, sendo financiado pelo Programa Brasileiro do Álcool (Pró-Álcool) a partir de 1975, e passou a figurar nos centros de pesquisa ao ser largamente utilizado como substituto à gasolina nos transportes rodoviários em veículos exclusivos fabricados para o mercado automotivo brasileiro. Nos anos da década de 1980, principalmente a partir de 1986, por muitos motivos, majoritariamente econômicos e produtivos, as refinarias deixaram de produzir etanol combustível suficiente para atender a demanda, causando um forte impacto no abastecimento do mesmo, minando sua a positiva utilização e retraindo seu mercado. O Brasil comprovou seu pioneirismo no campo do etanol combustível contudo, seu retorno, anos mais tarde, foi viabilizado somente em decorrência de uma revolucionária tecnologia desenvolvida nos EUA, a qual possibilitava os veículos automotivos a funcionar tanto com gasolina quanto com etanol em misturas de qualquer proporção entre ambos, ficando conhecido como veículos bicombustível ou flexfuel. Essa tecnologia surgira no final da década de 1980 fruto das pressões exercidas pelo estado da Califórnia, EUA por carros menos poluentes, tornando-se efetivamente comercializável em 1993, quando foram fabricados os primeiros carros bicombustível no mundo. No Brasil essa tecnologia encontrava-se em fase de testes desde o começo dos anos da década de 1990 contudo, somente ao final de 2002, quando sua regulamentação foi concluída, é que o mercado brasileiro pode desfrutar das vantagens comerciais (e, porque não, ambientais) dos veículos bi-combustível; grandes montadoras, como a alemã Volkswagen e a norte-americana General Motors Corporation, logo introduziram seus veículos flexfuel no Brasil e, poucos anos mais tarde, esses veículos já correspondiam à maioria esmagadora das vendas de automóveis novos no país (cerca de $85 \%$ ), posicionando o Brasil novamente na vanguarda dos assim denominados combustíveis verdes. Em 2007 o Brasil passou a possuir um veículo de grande porte, um ônibus, movido a etanol (95\% de AEHC e 5\% de aditivo suíço importado) - ao invés de óleo diesel - em 
circulação, tendo sido o protótipo apresentado no campus central da Universidade de São Paulo (USP), em outubro daquele ano, tendo entrado em circulação em dezembro, operando numa rota que compreende quatro municípios da região metropolitana da cidade de São Paulo; oito cidades européias estão envolvidas com o Brasil na parceria do ônibus movido a etanol. A vantagem do ônibus a etanol é a redução de $90 \%$ das emissões de material particulado, 62\% de $\mathrm{NO}_{\mathrm{x}}, 80 \%$ de GEE e a total isenção de componentes de enxofre (S), graças às qualidades do combustível, tudo isso a um custo estimado de R\$ 450.000,00, considerado pela USP, próximo ao do ônibus convencional; outra importante vantagem desse veículo é atender as normas ambientais da comunidade européia (EURO 5 e EEV) que passarão a ser efetivas a partir de 2010 (informação online) ${ }^{16}$. Conforme é apontado por Ortiz (2006), o Brasil é o maior produtor de cana-de-açúcar do mundo, seguido pela Índia, Tailândia e Austrália, sendo responsável por $45 \%$ de toda a produção mundial e forma com os EUA, a dupla de maiores produtores mundiais de etanol de cana-de-açúcar e milho respectivamente.

De acordo com o Plano Nacional de Energia, o processo de produção de etanol no Brasil é o mais avançado pois, para cada unidade energética empregada no processo de obtenção, são geradas cerca de 8 unidades energéticas em forma de etanol enquanto que, no processo norte-americano, que utiliza o milho como insumo produtivo, essa relação é de cerca de 1 para 1,3 atualmente; vale destacar que no processo brasileiro é comum a utilização do bagaço da cana-de-açúcar para a geração de energia para abastecimento da própria refinaria, processo esse conhecido como co-geração, aumentando assim a eficiência do processo.

Segundo Bajay (2005) em estudos realizados pelo Núcleo Interdisciplinar de Planejamento Energético (NIPE), da Universidade Estadual de Campinas (UNICAMP), o futuro da tecnologia agrícola envolvendo a cana-de-açúcar residirá no aprimoramento genético da biomassa energética; ajustes na adubação das espécies cultivadas envolvendo técnicas para uma agricultura de precisão, como por exemplo, o plantio direto com controle de tráfego que apresenta apenas $3 \%$ de terra cultivável pisoteada, contra $30 \%$ dos procedimentos convencionais.

\footnotetext{
${ }^{15}$ Material publicado na QMCWEB (4 $4^{\mathrm{a}}$ ano), a revista eletrônica do departamento de química da Universidade Federal de Santa Catarina (UFSC) em seu website: <http://www.qmc.ufsc.br/qmeweb/artigos/etanol.html/> Acesso em 28 de novembro de 2008.

16 Material extraído do website da Empresa Metropolitana de Transportes Urbanos (EMTU) do estado de São Paulo, disponível em <http: http://www.emtu.sp.gov.br/> . Acesso em 20 de dezembro 2008.
} 
Os melhoramentos genéticos, frutos da moderna engenharia genética, poderão significar, num período de 20 anos, um aumento de 15\% nos ganhos da produtividade, assim como outras estratégias de plantio e mapeamento da produtividade prometem majorar em até $25 \%$ esses ganhos. Assim, em se tratando da cana-de-açúcar, sua produtividade agrícola poderá aumentar, dentro desse espaço de tempo, de 71 ton/ha para 98 ton/ha e a longevidade de um canavial poderia duplicar, passando de 5 anos para 10 anos de produtividade. Se considerar outros avanços tecnológicos, as perspectivas para o ano de 2025 indicam aumentos da eficiência de extração da cana-de-açúcar; um tratamento do caldo visando uma préconcentração; um maior grau alcoólico (de $9,5^{\circ} \mathrm{GL}$ para $12{ }^{\circ} \mathrm{GL}$ ) obtido por melhoramentos no processos de fermentação ao se fazer uso de temperaturas mais baixas e a eliminação de antibióticos; aprimoramento dos processos de destilação, desidratação e redução na produção de vinhoto, conduzindo dessa forma para rendimentos na faixa dos $99 \%$ de eficiência. As perspectivas para o etanol brasileiro são otimistas em muitos cenários econômicos estudados e esse, por sua vez, pode ser considerado com o mais importante biocombustível da atualidade.

Outro combustível relevante da primeira geração, de tamanha importância, é o biodiesel, consistindo em um de óleo diesel que pode ser obtido a partir de muitos tipos diferentes de matérias-primas renováveis como gorduras animais, óleos e gorduras residuais mas principalmente por óleos vegetais de espécies oleaginosas como a soja, o dendê, a mamona, a palma, o girassol dentre outras que variam em maturidade tecnológica. O biodiesel pode ser utilizado puro, diretamente nos motores de compressão do ciclo diesel - embora em alguns motores mais antigos pudessem ser precisos alguns ajustes - ou também em mistura de diversas proporções com o diesel petroquímico que, por enquanto, ainda apresenta o custo mais competitivo entre os dois. Atualmente a concentração de biodiesel no diesel petroquímico é indicada por meio de uma designação própria definida por "BX", onde X refere-se à porcentagem, em volume, do biodiesel, misturada ao diesel petroquímico correspondendo, dessa forma, a 5\% no B5; 20\% no B20 e 100\% no B100. A obtenção do biodiesel se dá, basicamente, através do processo de transesterificação alcoólica por via catalítica ácida, básica ou enzimática, a esterificação direta ou o craqueamento térmico ou catalítico.

O biodiesel é o éster obtido através da reação de ácidos graxos e um intermediário ativo, formado pela reação de um álcool com um catalisador, ou pela substituição da molécula de glicerol dos triglicerídeos por três moléculas de álcool. Quando a reação para a obtenção de ésteres utiliza triglicerídeos, é dita transesterificação, sendo obtidos como produtos um éster (o biodiesel) e um glicerol. Nos casos em que o ácido graxo é 
processado, tem-se uma reação de esterificação, na qual se obtém como produtos o biodiesel e a água (OLIVEIRA, 2004).

As espécies vegetais oleaginosas passíveis de utilização para produção de biodiesel podem variar de acordo com a regionalidade e a sazonalidade assim como de acordo com as propriedades dos óleos empregados. Dado o fato de que a transesterificação pode suportar diferentes catalisadores, é comentado por Bajay (2005) que, embora a catálise básica seja mais interessante, a escolha da matéria-prima é importante para a decisão entre base/ácido; já a catálise enzimática apresenta menos subprodutos como uma de suas vantagens, contudo ainda se encontra em fase de desenvolvimento e, por fim, transesterificação etílica, embora mais complexa que a rota metílica, é deveras mais atrativa para o Brasil e poderá, no futuro, atingir níveis equivalentes de qualidade.

Ainda há o processo conhecido como H-Bio que foi desenvolvido visando a inserção de uma matéria-prima renovável no processo de refino do petróleo, proporcionando a mistura de óleos vegetais ou animais com as frações do diesel petroquímico, utilizando as instalações industriais já existentes e posterior hidroconversão em unidades de hidrotratamento (HDT) responsáveis pela redução no teor de enxofre, melhor ignição, melhorando assim a qualidade do combustível. Essa tecnologia foi desenvolvida no Brasil e segundo o Plano Nacional de Energia 2030, está prevista a implantação dessa tecnologia em cinco refinarias no país, permitindo a produção de $425.000 \mathrm{~m}^{3} /$ ano de H-Bio. O Centro de Pesquisas da Petrobras (CENPES) tem realizado testes em uma planta piloto com diferentes proporções de óleos vegetais buscando uma quantidade ótima que possa ser suportada pelo processo de HDT e possui perspectivas otimistas no que se refere ao futuro do H-Bio.

Segundo Suarez e Meneghetti (2007) atualmente a Alemanha é responsável por mais da metade da produção biocombustíveis na EU, podendo contar com centenas de postos de abastecimento onde é vendido biodiesel B100 (biodiesel puro) - o total produzido na Europa já ultrapassa 1 bilhão de litros/ano e essa tendência deverá continuar nos próximos anos: os biocombustíveis de primeira geração podem ser vistos como os favorecedores da transição energética até a chegada dos biocombustíveis sintéticos da segunda geração. 


\subsubsection{Segunda geração de biocombustíveis}

Os biocombustíveis pertencentes à segunda geração, também denominados biocombustíveis avançados, são aqueles produzidos por diversas variedades de biomassa desde resíduos até materiais lignocelulósicos - que não são, em sua maioria, utilizadas na alimentação humana, diferentemente dos combustíveis da primeira geração que utilizam produtos agroindustriais como insumo de produção, como é o caso do etanol de cana-deaçúcar ou de milho, por exemplo, ou ainda o biodiesel cujas matérias-primas são espécies vegetais oleagionas como a soja, dentre algumas outras.

A segunda geração destacou-se por buscar superar algumas das limitações presentes nos combustíveis da primeira geração como, por exemplo, o limiar entre produzir combustíveis suficientes sem, de alguma forma, prejudicar culturas agrícolas direcionadas para a alimentação. Uma grande vantagem desses combustíveis é, precisamente, fazer uso de culturas que não são adequadas para o consumo humano ou animal e assim contribuir de forma positiva para a situação dos biocombustíveis uma vez que, um dos principais receios que os cercam, diz respeito à competição entre fins energéticos e fins alimentícios dos produtos agrícolas; dessa forma é possível fazer uso das partes do vegetal que são, comumente, descartadas por não apresentarem potencial energético aparente, ou seja, importante mencionar que, a matéria vegetal poderá ser utilizada por inteira, sem comprometimento de sua unidade ou desperdícios, ao invés de apenas parte dela como no caso da cana-de-açúcar, por exemplo, onde somente sua seiva participa ativamente da obtenção do combustível.

Outra destacada vantagem está no fato de que as tecnologias da segunda geração de biocombustíveis possibilitam a utilização de culturas oriundas de solos pobres - além dos, já esperados, detritos provenientes dos agronegócios, madeira reciclada e material que já pertenceu à indústria moveleira - oferecendo, dessa forma, alternativas rentáveis para regiões menos favorecidas em termos de geologia e clima.

Diante de um contexto global onde a procura por soluções energéticas em torno da biomassa envolve altos custos de terras cultiváveis e custosas tecnologias torna-se prudente uma busca por alternativas que vão além do simples emprego da matéria-prima cultivada, explorando ao máximo seu potencial energético latente. Os principais combustíveis pertencentes às segunda geração são: (1) o bio-etanol ou etanol celulósico, cuja rota de obtenção consiste na utilização de ácidos ou enzimas em processos conhecidos como hidrólise 
ácida ou enzimática, respectivamente, que permitem que a celulose e a hemicelulose (contendo pentoses e hexoses) do bagaço da cana-de-açúcar sejam convertidas em etanol. De acordo com Bajay (2005) a conversão da biomassa lignocelulósica em álcool etílico pode ocorrer em duas etapas sendo a primeira um dos dois processos hidrolíticos supracitados e a etapa seguinte um processo de fermentação dos açúcares que estavam contidos nos complexos carboidratos, como a celulose e lignina, presentes, por exemplo, na biomassa que seria descartada após o convencional processo de obtenção fermentativa da sacarose ou do amido, respectivamente da cana-de-açúcar e do milho.

Há ainda os processos compreendidos em apenas uma etapa, o SFS que consiste em fermentação e sacarificação simultâneas e o CDM, de conversão direta microbiana, combinando a produção de enzimas à hidrólise da celulose e à fermentação da sacarose; dados apresentados pelo CENPES, em outubro de 2007, com valores baseados na safra de 2005, indicam que, (1) para a produção do bio-etanol, o aproveitamento do bagaço excedente da cana-de-açúcar poderia gerar 3.3 bilhões de L/ano e o aproveitamento da palha da cana-deaçúcar poderia gerar 10 bilhões de L/ano; (2) os combustíveis líquidos sintéticos que podem ser produzidos a partir de qualquer matéria constituída dos elementos químicos carbono (C) e hidrogênio $(\mathrm{H})$, como as matérias vegetais (biomassas) sendo os processos baseados na rota termoquímica conhecida como gaseificação, capaz de gerar o bio gás de síntese (biosyngas) principal insumo para a síntese Fischer-Tropsch capaz de constituir uma grande gama de hidrocarbonetos gasosos, líquidos e sólidos de onde é possível obter-se gasolina, óleo diesel, querosene, dentre outros e que, futuramente, essa tecnologia servirá de pilar para as biorrefinarias, conforme apresentado no Plano Nacional de Energia 2030, um conceito originado nos anos da década 1990 em alusão às refinarias de petróleo, onde será possível uma estrutura sustentável e integrada baseada na matéria-prima vegetal como fonte principal para a produção de toda uma cadeia química e industrial energética além de reunir processos produtivos para alimentação humana, envolvendo também tecnologias de fermentação do álcool etílico, numa clara integração entre os campos da bioengenharia, química de polímeros e ciência dos alimentos e agrícolas (KAMM et al., 2006); (3) o bio-DME (éter dimetílico) e o bio-metanol (álcool metílico) que também utilizam o biosyngas para sua obtenção e recentes pesquisas têm indicado o primeiro como um potencial combustível veicular, e há ainda a tecnologia de conversão do biosyngas em olefinas, conhecida como GTO (Gas-to-Olefins) e baseia-se no processo MTO (Methanol-to-Olefins); (4) o diesel HTU (Hydro Termal Upgrading) que consiste em uma tecnologia de obtenção de combustível a partir de uma biomassa com grande umidade, como o bagaço da cana-de-açúcar, por exemplo, sendo essa 
biomassa convertida em um denso líquido orgânico contendo uma mistura de hidrocarbonetos, chamado de biocrude, que posteriormente sofre um processo catalítico específico e assim obtêm-se o óleo diesel, sendo a Holanda o país detentor de pesquisas avançadas nesse campo (KERSSEN; BERENDS, 2004). Pode-se destacar ainda o biometanol, o bio-hidrogênio e o bio gás-natural, todos tendo seu processo iniciado pela gaseificação da biomassa.

No que diz respeito aos combustíveis da segunda geração é válido mencionar que pesquisas envolvendo biomassa transgênica se situam como uma peça promissora em seu desenvolvimento através da chamada biologia sintética que propõe construir ou redesenhar partes e sistemas biológicos que não existem no mundo natural e assim aperfeiçoar espécies vegetais para majorar seu potencial energético aproveitável. Em termos comparativos preliminares, segundo Kerssen e Berends (2004), a quantidade de energia necessária para a produção de alguns biocombustíveis é, em ordem crescente (esquerda para direita) demonstrado a seguir, onde os líquidos FT são considerados oriundos do biosyngas e o etanol sendo obtido pelos processos convencionais utilizando-se cana-de-açúcar ou milho:

$(-)$ Óleo Diesel $\rightarrow$ Biodiesel $\rightarrow$ Diesel HTU $\rightarrow$ Líquidos FT $\rightarrow$ Etanol $(+)$

O óleo diesel petroquímico figura para apenas estabelecer um comparativo com os biocombustíveis. Da mesma forma há ainda a comparação da quantidade de gases de efeito estufa (GEE) liberados durante o processo de obtenção desses combustíveis:

$(-)$ Diesel HTU $\rightarrow$ Líquidos FT $\rightarrow$ Biodiesel $\rightarrow$ Etanol $\rightarrow$ Óleo Diesel $(+)$

Ainda, de forma preliminar, é possível realizar uma estimativa de quais seriam os preços praticados para esses combustíveis (€/GJ) num período de tempo compreendido entre os anos de 2015 e 2025 onde ter-se-ia o diesel HTU ( $€$ 5,0); o óleo diesel petroquímico ( $€$ 6$7,0)$; o diesel FT (€ 7,0); o etanol (€ 9-10,0) e por fim o biodiesel ( $€ 25,0)$, sendo o etanol mencionado obtido através do processo de hidrólise enzimática (etanol celulósico).

Grandes corporações ao redor do mundo investem em pesquisas objetivando novos biocombustíveis numa tentativa de diversificar a aprimorar a matriz energética no que tange os combustíveis veiculares, como é o caso da Standard Alcohol Company of America, Inc., que desenvolveu o Envirolene, um combustível que consiste em uma mistura de álcoois e apresenta a vantagem de ser biodegradável no ar, água e solo (informação online) ${ }^{17}$; há ainda 
o Ecalene, biocombustível de alta performance desenvolvido pela Power Ecalene Fuels, Inc., que apresenta o expressivo valor de 124 (ou superior) para seu NO e estima reduzir em até $90 \%$ as emissões de poluentes quando comparado com a gasolina petroquímica tradicional (informação online) $)^{18}$.

O que poderá seguir a essas e outras tecnologias é o conceito da terceira geração de biocombustíveis onde a biomassa oceânica sustentará as bases do desenvolvimento de novas tecnologias de transformação de matéria orgânica em combustíveis. Alguns estudos preliminares realizados pelo Departamento de Energia dos Estados Unidos (US Department of Energy - DOE) apontam que as algas possuem um potencial energético cerca de 30 vezes maior, por acre cultivado, se comparado ao das demais culturas tradicionais como a soja, por exemplo; além do mais sua estrutura celular é mais simples do que a dos vegetais terrestres, sua disseminação é mais rápida, inclusive em águas salgadas, e em algumas usinas nos EUA as algas têm sido testadas como agente absorvedor de carbono uma vez que podem ser cultivadas em espaços confinados. O óleo combustível processado a partir da biomassa aquática tem sido chamado, por alguns pesquisadores e ambientalistas, de oilgale e, segundo Matthew Caspari, CEO da Auroa Biofuels - uma empresa pioneira nesse campo de pesquisa, situada em Berkeley, Califórnia - esse é um processo tecnologicamente viável porém de custo ainda elevado demais para ser comercializado (informação online) ${ }^{19}$. Por hora os biocombustíveis da segunda e terceira geração, possuem apenas um papel figurativo nos cenários energéticos dos próximos anos, sinalizando alternativas que poderão, talvez, um dia, se concretizarem de alguma forma que seja comercialmente viável.

\footnotetext{
${ }^{17}$ Material extraído do website da empresa Standard Alcohol Company of America, Inc. Disponível em $<$ http://www.standardalcohol.com/biofuel.htm>. Acesso em 16.novembro.2008

18 Material extraído do website da empresa Power Ecalene Fuels, Inc. Disponível em $<$ http://powerecalene.com/product.php >. Acesso em 16.novembro.2008

${ }^{19}$ Material extraído do website do Departamento de Energia dos Estados Unidos (US Department of EnergyDOE) Disponível em < http://energy.org > . Acesso em 16.novembro.2008
} 


\section{DISCUSSÃO E CONCLUSÕES}

Os biocombustiveis atuais têm inconvenientes que deverão desaparecer com os combustíveis sintéticos, ditos de segunda geração.

(Edgard Gnansounou)

Atualmente as linhas tecnológicas que delineiam os vertentes da competitividade no que diz respeito à produção de biocombustíveis derivam (1) da dimensão agrícola, que por sua vez deverá contribuir de uma forma que as matérias primas apresentem a maior eficiência possível e incorram em um menor impacto ambiental; e (2) na dimensão industrial onde residem os processos de transformação das matérias primas em fontes energéticas secundárias. Muitos esforços visam à correta alocação dos recursos hídricos e à vida do solo em questão e um eficiente conceito de supply chain, desde o processo de colheita, transporte e armazenamento, maturação da espécie vegetal, minimização de perdas de processo e da deterioração da matéria vegetal. Assim que os processos de produção agrícola forem otimizados, com a correta adequação dos vegetais aos objetivos energéticos, por exemplo, será a vez da bioenergia e das rotas tecnológicas industriais que variam em propósito e complexidade, não mais visando apenas a produção de biocombustíveis de alta qualidade, mas também de produtos petroquímicos de base e a geração de energia elétrica; e por fim a compreensão das restrições econômicas, sociais e ambientais das regiões a serem exploradas para o plantio das culturas dedicadas aos fins energéticos e as externalidades que recaem sobre elas.

Com o advento da primeira e da segunda geração de biocombustíveis um horizonte de possibilidades vem tomando lugar dentro da matriz energética mundial, apresentando diversas tecnologias que proporcionarão um real suporte ao sistema de abastecimento de combustíveis priorizando a geração de trabalho. Dentro desse leque de opções encontram-se os biocombustíveis sintéticos gasolina e óleo diesel que podem ser aplicados, em um primeiro momento, diretamente nos motores veiculares dos ciclos Otto e Diesel sem que haja a necessidade de adaptações mecânicas para suportá-los, como é o caso de outras tecnologias automotivas alternativas, por exemplo, o gás natural veicular (GNV) ou a célula a combustível. De acordo com Hamelinck et al. (2003) a gasolina obtida pela síntese FT não 
apresenta qualidade suficiente para ser utilizada diretamente como combustível veicular, dado seu baixo número de octano $(\mathrm{NO})$, cabendo a ela um papel secundário no planejamento energético, podendo, talvez no futuro, ser utilizada como componente da mistura final (pool) das gasolinas automotivas; ou submetida a processos químicos que a tornem uma gasolina de uso final, ou ainda ser utilizada como parte da matéria-prima para obtenção dos assim denominados plásticos "verdes". É importante frisar que mesmo não atendendo às especificações de mercado para sua pronta comercialização, a gasolina FT apresenta indiscutíveis vantagens ambientais no que se refere à isenção de elementos químicos danosos ao meio ambiente e às emissões de GEE.

Segundo Boerrigter (2002) e Greene apud Pinheiro (2002) o diesel FT, também chamado de syn-diesel e algumas vezes referenciado como diesel "verde" ("green" diesel), apresenta-se como um combustível veicular de elevada qualidade por possuir um NC de 76 (pouco mais que o dobro da maioria dos óleos diesel comerciais); em sua composição há isenção de enxofre o que acarreta em 0 \% (zero) de emissões de $\mathrm{SO}_{\mathrm{x}}$; há isenção de hidrocarbonetos aromáticos, proporcionando uma combustão mais limpa ao reduzir em cerca de $40 \%$ as emissões atmosféricas de material particulado e em $20 \%$ as emissões de $\mathrm{NO}_{\mathrm{x}}$, podendo ser utilizado também em misturas com outros óleos diesel - sintético (CTL/GTL), biodiesel ou o produzido da petroquímica tradicional; ainda há Baitz et al. apud Opdal (2006) que indicam que é possível uma redução de $87 \%$ nas emissões de dióxido de carbono $\left(\mathrm{CO}_{2}\right)$ ao se utilizar o diesel FT em substituição ao diesel petroquímico, reduzindo drasticamente a emissão de um dos principais GEE.

No contexto tecnológico e produtivo atual ao se utilizar 1 tonelada de biomassa lenhosa como matéria-prima é possível atingir-se uma eficiência entre 80\% e 90\% de conversão em hidrocarbonetos na síntese FT ao se empregar dois ou três estágios de reações e/ou separações, afirma Bartholomew apud Hamelinck et al. (2003), sendo 80\% de hidrocarbonetos com cadeias carbônicas contendo cinco ou mais $\left(\mathrm{C}_{5+}\right)$ átomos de carbono, gerando $120 \mathrm{~L}$ de ceras FT que, através de hidrocraqueamento, produzem 100L de diesel FT. Horizontes produtivos prevêem um aumento desse rendimento onde será possível obter, por tonelada de biomassa utilizada como matéria-prima, 210L de produto, tornando a eficiência produtiva uma meta crucial para os próximos anos, conforme pode ser observado no gráfico (5.1) uma estimativa dos custos cumulativos, envolvidos na cadeia produtiva e de abastecimento do diesel FT para um cenário comercial a partir do ano de 2010. 


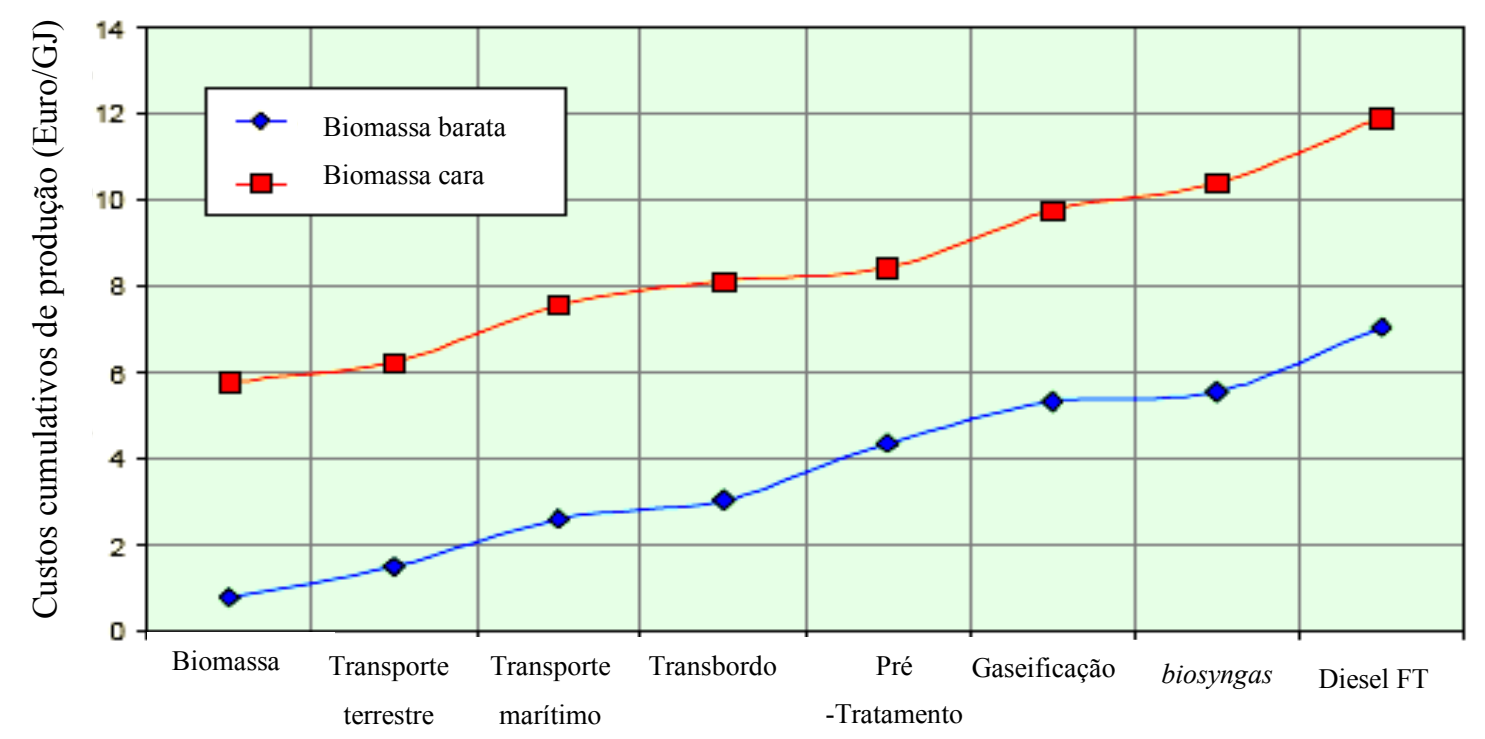

\section{Gráfico 5.1 Custos cumulativos para produção em larga escala de diesel FT}

Fonte: (Adaptado de BOERRIGTER, 2002)

Dentro deste mesmo cenário as perspectivas de comercialização para o diesel FT, quando comparado ao diesel petroquímico e outros potenciais biocombustíveis, seus custos produtivos $(€ / G J)$ os posicionam na seguinte ordem: diesel petroquímico (€ 3-6,0) considerando US\$ 15-30/barril do petróleo; diesel FT (€ 7-12,0); bio-etanol (€ 9-13) e o biodiesel ( $€$ 14-24) tendo os dois últimos seus preços dependentes de subsídios. É válido apresentar que uma importante diferença entre o diesel FT, quando comparado ao biodiesel convencional, é que o mesmo não necessita de terras cultiváveis para obtenção de sua matéria-prima, não sofrendo, por conseqüência, do aumento da demanda originada por culturas agrícolas que se destinam à produção de alimentos. O diesel FT poderá atingir uma significativa parcela do mercado de biocombustíveis, como é objetivado pela CHÖREN Fuel Freiberg GmbH \& Co. KG, em Friburgo, Alemanha, por esta ser a primeira planta de biocombustíveis sintéticos em escala comercial no mundo; operando pela rota BTL foi concluída em abril de 2008 e, portanto, pioneira e a maior dentro dessa categoria. De acordo com estimativas da empresa, até 2015 a CHÖREN deverá suprir, com seu diesel sintético batizado de SunDiesel ${ }^{\circledR}, 15 \%$ de todo o consumo de combustíveis veiculares da Alemanha e com a vantagem de que a queima desse diesel libera o carbono contido nele na mesma proporção que foi, num momento anterior, absorvido pela biomassa utilizada como matériaprima podendo considerá-lo como um combustível cujo potencial de emissões atmosféricas de carbono é zero. (CHÖREN Industries, BTL-Plant Freiberg, 2007) 
Os combustíveis menos poluentes oriundos da biomassa energética, possuem um crescente mercado em potencial e essa realidade poderá significar uma vantajosa posição para os países detentores das tecnologias de conversão, economicamente viáveis, numa escala industrial. De acordo com dados do Plano Nacional de Energia 2030, a tecnologia Biomassto-Liquids (BTL) encontra-se em um estado de desenvolvimento em nível de "planta-piloto" e o custo do investimento de uma planta em escala comercial pode se aproximar de US\$ 140.000,00 por barril de capacidade segundo um estudo conduzido pelo Department of Energy (DOE) dos EUA, no ano de 1998. Esse nível de investimento, embora estimado, pode ser comparado com aqueles utilizados em plantas cujas rotas empregadas são a CTL e a GTL e que já sofreram reduções ao longo do tempo, cabendo às inovações tecnológicas e economias de escala reduzir os custos da tecnologia BTL que, por sua vez, caracteriza-se por ser uma tecnologia nova e evolutiva.

Segundo dados publicados em 2006 pela Energy Information Administration (EIA) dos EUA, grandes plantas que operam pela rota BTL demandam grandes áreas para a produção em estágios e os custos são altos para o transporte da matéria-prima para tratamento e armazenamento e depois para ser processada na planta; ainda há questões que cercam os processos da gaseificação da biomassa, no que diz respeito aos seus avanços tecnológicos, se estes seriam capazes de reduzir o custo do processo para tornar a rota BTL mais competitiva. Há alguns anos, o potencial da gaseificação poderia ser duvidoso, contudo, atualmente, ele é promissor; dessa forma, não se deve desanimar frente aos eventuais momentos de estagnação tecnológica que, possivelmente, virão a ser superados, dando assim, continuidade do desenvolvimento de uma dada tecnologia. Outro ponto a ser considerado é o elevado custo dos catalisadores empregados no processo Fischer-Tropsch podendo contribuir, juntamente com os outros aspectos mencionados, para a estagnação dessa tecnologia.

Mesmo diante de barreiras as perspectivas para essa tecnologia são promissoras pois há interesse de muitos agentes das cadeias produtivas de carvão e gás natural, assim como de empresas detentoras de inovadoras tecnologias, sejam pelas oportunidades latentes e possíveis ganhos significativos ou seja pelas constantes - e crescentes - pressões ambientais. Segundo dados apresentados no Plano Nacional de Energia 2030 é passível de verificação a expansão da participação dos biocombustíveis na matriz energética mundial, tendo a participação do etanol aumentado de $13 \%$ para $19 \%$ e a do biodiesel de 0 (zero) para $5 \%$, atingindo um expressivo valor de $24 \%$ no que tange os combustíveis veiculares quando a referência é a matriz energética brasileira. Uma crescente demanda toma lugar no mercado internacional por biocombustíveis e espera-se um significativo aumento na produção desses pois, se utilizados 
de forma sustentável de acordo com as necessidades de uma sociedade em constante demanda, os processos de conversão da biomassa poderão guardar as chaves de uma nova vanguarda energética. 


\section{REFERÊNCIAS}

AL-SHALCHI, W. Gas to liquids technology. Baghdad, Iraq, 2006. 69 p.

ANDRADE, R.V., et al. Gaseificacão de biomassa em leito fluidizado: Avaliação de um reator operando com casca de arroz como combustível. In Congresso Iberoamericano de engenharia mecânica, 8 , 2007, Cusco, Peru. Universidade Federal de Itjubá, São Paulo, 8 p.

ANTUNES, A. M. S. Monitoramento da Qualidade dos Combustíveis Automotivos no Estado do Rio de Janeiro. In Congresso de Extensão da UFRJ, 2², 2001, Rio de Janeiro-RJ.

APOLINARIO, S.M.Geração de eletricidade em comunidades isoladas na região amazônica com a utilização de gaseificadores de biomassa. Dissertação (Mestrado). Universidade de São Paulo, São Paulo, 2006. 186 p.

AUDI, R.; FIASCHI, A. Gaseificação de biomassa: Biomass-to-Liquids - Projeto para produção de combustíveis renováveis e produtos químicos a partir da biomassa São Paulo: Raudi Indústria e Comércio Ltda., 2005. p. 14. Apresentação em arquivo .ppt.

BAJAY, S.V., Perspectivas de avanços tecnológicos na produção de álcool e biodiesel no Brasil. Campinas:[s.n.],[2005]. Não publicado.

BALABIN, R.M.; SAFIEVA, R.Z. Gasoline classification by source and type based on near infrared (NIR) spectroscopy data. Gubkin Russian State University of Oil and Gas. Russia: Elsevier, p. 1096-1101, august, 2007.

BARTOK, W. Combustion of synthetic fuels. Washington, D.C., USA: American Chemical Society, 1983. ( ACS Symposium series 217).

BENTE Jr., P. F. The Bio-Energy Directory. Washington D.C. 20006, U.S.A.: The BioEnergy Council, 1980.

BEST, R.W. Gasoline octane rating methods and operational conditions in two strokes engines. 2002. Disponível em: <http://www.ozebook.com/compendium/suzi/octane.pdf> Acesso em 05 mar. 2002.

BIZZO, W.A. Tecnologias da biomassa para conversão de energia. Campinas: Faculdade de engehnaria mecânica, Universidade Estadual de Campinas - UNICAMP, 2007. 
BOYLE, G. Renewable energy: power for a sustainable future. Oxfordshire, England: Oxford University Press, Oxford University, 1996.

BOERRIGTER, H. "Green” diesel production with Fischer-Tropsch synthesis. In: Business Metting Bio-Energy, Platform Bio-Energie, September 13, 2002. ECN-RX--03-014.

BROWNLOW, A.H. Geochemistry. Englewood Cliffs: Prentice-Hall, 1979..In: MAJOR, T. J. Genesis and the origin of coal and oil. $2^{\text {nd }}$ Edition. Montgomery: Apologetics Press Inc, 1996. $20 \mathrm{p}$.

CALLARI, R. Produção de óleo diesel limpo a partir do gás natural: estudo de viabilidade técnico-econômica para uma instalação de uma planta GTL (Gas-to-Liquids) no Brasil. Tese (Doutorado) Universidade de São Paulo, São Paulo, 2007, 83 p.

CAMPOS, A. C.; LEONTSINIS, E. Petróleo \& Derivados. Rio de Janeiro: JR Editora Técnica, 1990.

CARIOCA, J. O. B.; ARORA, H. L. Biomassa: Fundamentos e aplicações tecnológicas. Fortaleza: Universidade Federal do Ceará, 1984.

CENBIO - Centro Nacional de Referência em Biomassa. Comparação entre tecnologias de gaseificação de biomassa existentes no Brasil e no exterior e formação de recursos humanos na região norte: Estado da arte da gaseificação. São Paulo: CENBIO, Setembro, 2002.

CHÖREN Industries, BTL-plant Freiberg, SunDiesel ${ }^{\circledR}$ made by Choren, Freiberg, Germany, 2007. p.63

CONEJERO, M.A., Marketing de créditos de carbono: um estudo exploratório. Dissertação (Mestrado). Universidade de São Paulo, Faculdade de Economia, Administração e Contabilidade de Ribeirão Preto, São Paulo, 2006, 206 p.

CÔCCO, L.C.; YAMAMOTO, C.I.; von MEIEN, O.F. Study for correlations for physicochemical properties of Brazilian gasoline. Paraná: Universidade Federal do Paraná:. Elsevier, p. 55-63, September, 2004.

COOVATTANACHAI, N. Biomass Gasification. Hadyai, Songkla, Tailândia: Asean SubCommittee on Non-Conventional Energy Research, 1990. 
CRUZ, J.F.M. Caracterização de gasolinas por espectroscopia FT-Raman. 2003. 215 p. Tese (Doutorado). Pontífie Universidade Católica do Rio de Janeiro, Rio de Janeiro, 2003.

De RENZO, D. J. Energy from Bioconversion of Waste Materials. New Jersey: Noyes Data Corporation, 1977.

DIJK, H.A.J. van. The Fischer-Tropsch Synthesis: A mechanistic study using transiente isotopic. Library Technische Universiteit Eindhoven, Países Baixos, 2001.

DUNHAM, F.B. et al.. Processo de Produção de Combustíveis Sintéticos: Análise das Trajetórias Tecnológicas. In: Congresso Brasileiro de P\&D em Petróleo e Gás, 2.ed., 2003, Rio de Janeiro.

DUNHAM, F.B.; BOMTEMPO, J.V.; e ALMEIDA, E.L.F. Trajetórias tecnológicas em combustíveis sintéticos: Análise dos mecanismos de seleção e indução. Revista brasileira de inovação. vol. 5, nº1, p. 99-129, jan.-jun., 2006,.

ENCICLOPÉDIA BARSA=Encyclopedia Britannica. Supervisão de Willian Benton. Rio de Janeiro: Encyclopedia Britannica Editores Ltda, 1967. 16 v.

ENVIRONMENTAL PROTECTION AGENCY. Disponível em: <http://www.epa.gov/> Acesso em 2008

FELTRE, R. Química Orgânica. 6a ed. Editora Moderna, 1995, 3 v., 427 p.

FERREIRA, A.A.; AQUINO NETO, F. R. de. Simulated distillation in the petroleum industry. Quím. Nova, São Paulo, v. 28, n. 3, 2005 . Disponível em: $<$ http://www.scielo .br/scielo.php?script $=$ sci_arttext\&pid $=$ S0100-40422005000300020\&lng $=$ en $\& n r m=i s o>$ Acesso em: 26 Mar 2008.

FERREIRA, F.O.; FLUMINGNAN, D.L.; OLIVEIRA, J.E. Determinação da composição e da octanagem de gasolinas $C$ por espectroscopia de $R M N^{l} H$ e regressão linear múltipla. In: PDPETRO, $4^{\circ}, 2007$, Campinas-SP. Centro de monitoramento e pesquisa da qualidade de combustíveis, petróleo e derivados (CEMPEQC).

FUEL. The World Book Student Discovery Encyclopedia. Chicago: World Book, Inc., 2005. $2 \mathrm{p}$. 
GARGIA, R. Combustíveis e combustão industrial. Rio de Janeiro: Editora Interciência, 2002. 197 p.

GEROSA, T. M. O estudo da utilização do gás natural como insumo para a indústria química e petroquímica: modelagem de uma planta gás-química. Dissertação (Mestrado) Universidade de São Paulo, São Paulo, 2007, 153 p.

GOLDEMBERG, J. et al.. Energy for a sustainable World. New Delhi :Wiley Eastern, 1988.

GOLDEMBERG, J., ZYLBERSZTAJN, D. Energy for a sustainable world. São Paulo: [s.n], 1999 . (Doc. No 99NN00AR07).

GREENHOUSE EFFECT AND CLIMATE CHANGE. Bureau of Meteorology. Australian Government. 74 p. Disponível em: $<$ http://www.bom.gov.au/info/GreenhouseEffectAnd ClimateChange.pdf $>$ Acesso em 18 fev. 2008.

HAMELINCK, C.N. et al.. Production of FT transportation fuels from biomass; Technical options, process análisis and optimisation and development potential. Utrecht University, Utrecht, Netherlands, 2003, 69 p.

HASLER, P.; NUSSBAUMER, T. H. Gas cleaning for IC engine application from fixed bed bimass gasification. Biomass and Bioenergy, v. 16, 1999. p. 385-395

HEDIN, L.O.; LIKENS, G.E. Atmosferic dust and acid rain. Scientific American. p. 1-5, december, 1996. Disponível em: <http://www.princeton.edu/ lhedin/Publications/96 ScientificAmer.pdf> Acesso em 21 fev. 2008.

HIGMAN, C.; van der BURGT, M. Gasification. Massachussets: Elsevier , 2003. p.391

JIANG, H. et al.. Gasification of Rice Husk in a Fluidized-Bed Gasifier Without Inert Additives, Industrial and Emgineering Chemistry Research. vol. 42,. p. 5745-5750, 2003

JUN, Y. A review of kinetics for Fischer-Tropsch synthesis. Department of Chemistry, Jinan University, Guangzhou 510632 China; $2^{\circ}$ State Key Laboratory of Coal Conversion, Institute of Coal Chemistry, Chinese Academy of Sciences, Taiyuan, China. 2004.

KAMM, B. et al.. Biorefineries - Industrial Processes and Products. Status Quo and Future Directions. Part I: Background and Outline - Principles and Fudamental Weinheim:. WileuVCH Verlag GmbH \& Co. KGaA, , 2006. Vol.1 
KARAYILDIRIM, T.; SINAĞ, A.; KRUSE, A. Char and coke formation as unwanted side reaction of the hydrothermal biomass gasification. Chemical Engineering Technology, Weinheim :Wiley-VCH, Verlag GmbH \& Co. KGaA, v.31, n. 11, p. 1-9, 2008.

KAWAKAMI, A.; SHIKADA, A.; MIYAO, K. JSAE. Rev. 21 (2003) 73-78.

KERSSEN, M; BERENDS, R.H. Lyfe cicle analysis of the HTU process. Dutch Research Organization for Environment, Energy and Process Innovation, Laan van Westnenk, Appeldorn, The Netherlands, [2004].

KLASS, D. L. Biomass for renewable energy, fuels, and chemicals. $1^{\text {st }}$ Edition. San Diego:. Academic Press, 1998. 651 p.

LORA, E.E. Gaseificação de Biomassa. Workshop de tecnologia BTL - Projeto programa de pesquisa em política públicas. Painel 3. Instituto de engenharia mecânica - IEM, Universidade Federal de Itajubá - UNIFEI, 2008.

MAJOR, T. J. Genesis and the origin of coal and oil. $2^{\text {nd }}$ Edition. Montgomery: Apologetics Press Inc, 1996. 20 p.

MELO, B.A. Avaliação computacional de umsistema de gaseificação em leito fluidizado utilizando o software CSBF. Dissertação, 2008. p. 137.Dissertação (mestrado)-Universidade Federal de Itajubá, Instituto de Engenharia Mecânica. Itajubá, Minas Gerais, 2008..

MESA, J.M.; ROCHA, J.D.; OLIVARES. E.; BARBOZA, L.A.; BROSSARD, L.E.; BROSARD JUNIOR, L.E. Pirólise rápida em leito fluidizado: uma opção para transformar biomassa em energia limpa. Revista Analytica, nº 4, maio, p. 32-36, 2003.

NEIVA, J., Conheça o petróleo. 6 ${ }^{\mathrm{a}}$ ed. Rio de Janeiro: Expressão e Cultura, 1993. 183 p.

NOGUEIRA, L. A.; LORA, H. Dendroenergia: Fundamentos e aplicações. 2.ed. 2003.

OLIVEIRA, L.B. Potencial de Aproveitamento Energético de Lixo e Biodiesel de Insumos Residuais no Brasil.2004. Tese (Doutorado). Programa de Planejamento Energético. COPPE / Universidade Federal do Rio de Janeiro - UFRJ, Rio de Janeiro, 2004. 
OPDAL, O.A. Production of syntetic biodiesel via Fischer-Tropsch synthesis: Biomass to liquids in Namdalen, Norway. Department of Energy \& Process engineering, Norwegian University of Science and Technology, Norway, december, 2006. 84 p.

OZONE. United States Environmental Agency. Office of Air and Radiation. Washington, DC, june 2003. 2 p. Disponível em: <http://www.epa.gov/airnow/gooduphigh/ozone.pdf $>$ Acesso em 18 fev.2008.

PAASEN, J.; KIEL, H.A. Tar Formation in Fluidised-bed Gasification - Impact of gasifier operation condictions. 2nd World Conference and Technology Exhibition on Biomass for Energy, Industry and Climate Protection. Roma, 2004.

PEREIRA, A.S. Mudança Climática e Energias Renováveis. Coordenação dos Programas de Pós-graduação de Engenharia, UFRJ. Rio de Janeiro, 2002. Disponível em:

$<$ http://www.comciencia.br/reportagens/clima/clima12.htm> Acesso em 17 jan. 2008.

PETROBRAS Distribuidora SA, website $<$ http://www.petrobras.com/ptcm/appmanager $/ \mathrm{ptcm} /$ dptcm?_nfpb=true\&_pageLabel=petr_com_pag_inicial $>$ Acesso em 2008.

PINHEIRO, B.B. Produção de combustíveis sintéticos a aprtir do gás natural: evolução e perspectivas . 2001.Universidade Federal do Rio de Janeiro, Rio de Janeiro, Julho, 2002.

PROBSTEIN, R.F.; HICKS, R.E. Synthetic Fuels. $1^{\text {st }}$ Edition. New York: McGraw Hill Book Company, 1982, 490 p.

ROCHA, P.S.; SOUZA, A.O.A.B.; CÂMARA, R.J.B. O futuro da bacia do Recôncavo, a mais antiga província petrolifera brasileira. RECAM - Rede Cooperativa de Engenharia em Campos Maduros. [entre 1997 e 2007] Disponível em: <http://www.recam.org.br/projetos/ projeto-1/publicacoes/revista_sei1.pdf/view> Acesso em 23 mar. 2008.

SALES, C.A.V.B; ANDRADE, R.V.; LORA, E.E.S. Geração de eletricidade a partir da biomassa, Biomassa e Energia ,vol. 2, n 3,. p. 195-204, 2005.

SISTEMA BRASILEIRO DE RESPOSTAS TÉCNICAS. Disponível em: $<$ http://www.sbrt.ibict.br/pages/index.jsp>. Acesso em 2008.

SCIENCE, v. 315, 9 de fev. 2007.

SCIENTIFIC AMERICAN. Portugal, ano 5, v. 53, out. 2006. Edição Especial Brasil. 
SPATH, P.L.; DAYTON, D.C. Preliminary screening - Technical and economic assessment of synthesis gas to fuels and chemicals with emphasis on the potential for biomass derived syngas. , USA :National Renewable Energy Laboratory, 2003.

STEVENS, D.J. Hot gas conditioning: recent progress with large-scale biomass gasification systems. Richland, Washington : Pacific Northwest National Laboratory, 2001. 103 p.

STEYNBERG, A.; DRY, M. Fischer-Tropsch Technology, Amsterdam :ELSEVIER, 2004. . vol.152

STRANGES, A. N. The US Bureau of Mines 'synthetic fuel programme. Annals of Science, 1997

SUAREZ, P.A.Z.; MENEGHETTI, M.S.P. 70 Aniversário do Biodiesel em 2007: Evolução histórica e situação atual no Brasil. Instituto de Química e Biotecnologia, Universidade Federal de Alagoas, Maceió, Alagoas, 2007. p.4.

USHIMA, A.H. Aspectos tecnológicos de gaseificadores e sistema de limpeza de gases. Instituto de Pesquisas Tecnológicas, São Paulo, 2002. p. 60.

USHIMA, A.H. Biomassa-Geração de gás de síntese. Instituto de Pesquisas Tecnológicas, São Paulo, 2006. p. 17

VASCONCELLOS, G. F. Biomassa: A eterna energia do futuro. São Paulo: Editora Senac, 2001.

VENTURI, V. et al.. Realação ar/combustivel e comsumo específico para formulação de diesel/biodiesel. In: Reunião Anual da Sociedade Brasileira de Química - SBQ, 25., 2002, Poços de Caldas, MG. Resumos. Rio Grande do Sul, Instituto de Química - Departamento de Físico-Química - Universidade Federal do Rio Grande do Sul. p. 1-2

VESSIA, Ø. Biofuels from lignocellulosic material - In the Norwegian context 2010 Tecnology, Potential and Costs. Norweigian University of Science and Tecnlogy - NTNU, Trondheim, Norway, 2005. p. 101 